\title{
Environmental Monitoring at the Lawrence Livermore Laboratory 1979 Annual Report
}

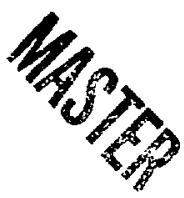

\author{
W. J. Silver, C. L. Lindeken
}

J. H. White, R. W. Buddemeir

April 25, 1980

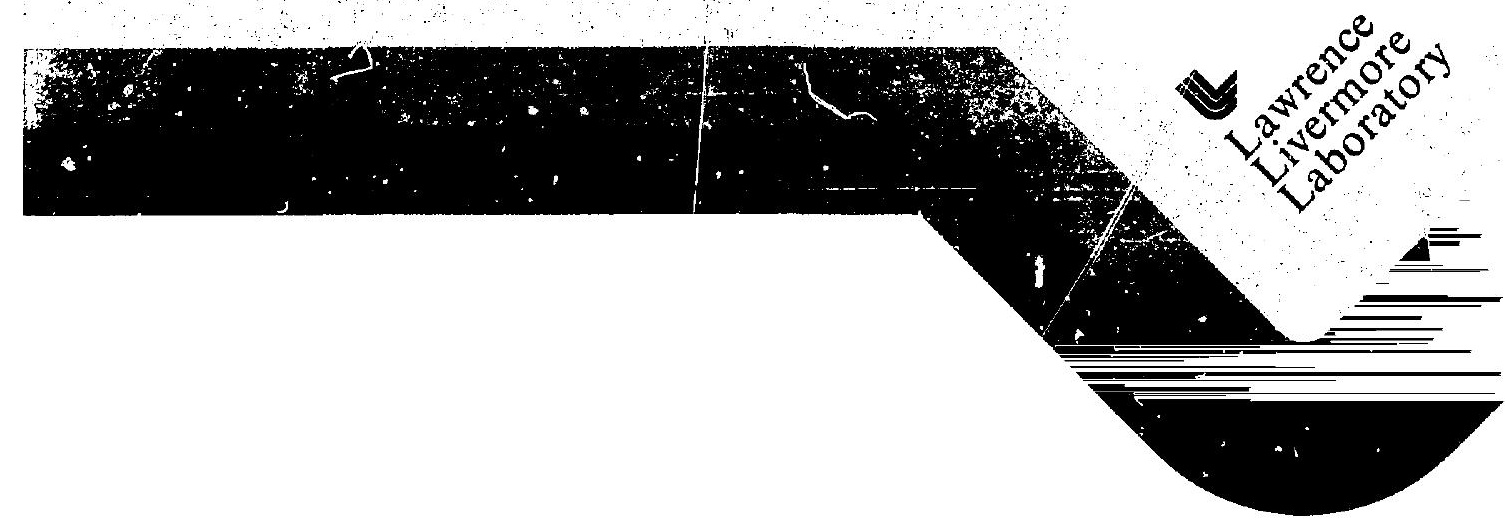


UCRL-50027-79

Distribution Category UC-11

\title{
Environmental Monitoring at the Lawrence Livermore Laboratory 1979 Annual Report
}

\author{
W. J. Silver, C. L. Lindeken
}

J. H. White, R. W. Buddemeir

Manuscript date: April 25, 1980

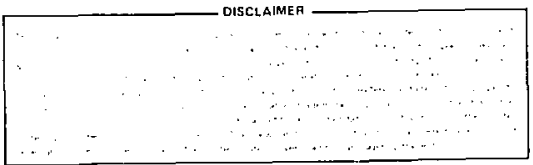

LAWRENCE LIVERMORE LABORATORY University of California - Livermore, California - 94550 


\section{FOREWORD}

This report is prepared for the U.S. Department of Energy by the Environmental Evaluations Group of the Hazards Control Department. Lawrence Livermore Laboratory. Data are obtained through the combined efforts of the Nuclear Chemistry Division, the Environmental Sciences Division, and the Hazards Control Department. In addition to the authors listed, the following persorinel made significant contributions to this report:

J. M. Bazan

E. K. Butterfield

H. C. Capwell

A. Conover

K. J. Davidson

R. J. Dupzyk

A. L. Gazlay

K. S. Griggs

R. Gunnink

D. W Hosmer
Y. M. Kwok

J. D. Lum

M. A. Auyong

K. R. Peterson

N. H. Rogers

C. W. Sundbeck

R. D. Szidon

A. J. Toy

K. M. Wong 


\section{CONTENTS}

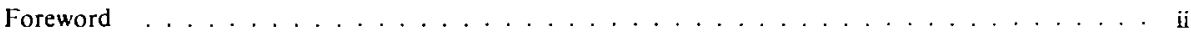

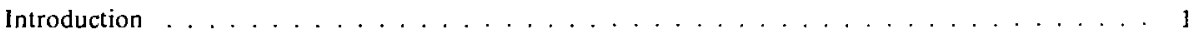

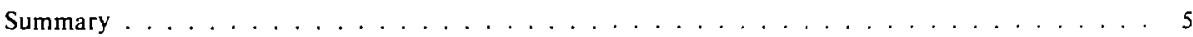

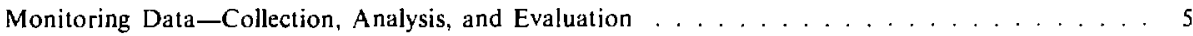

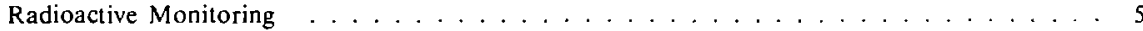

Airborne Radioactivity . . . . . . . . . . . . . . . . . . 5

Radioactivity in Soil . . . . . . . . . . . . . . . .

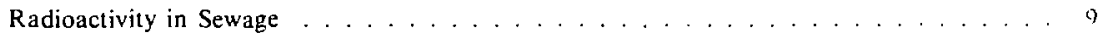

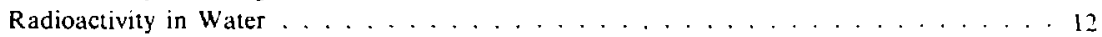

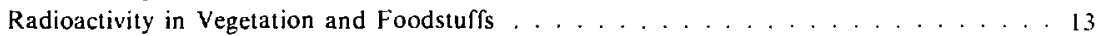

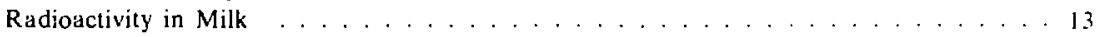

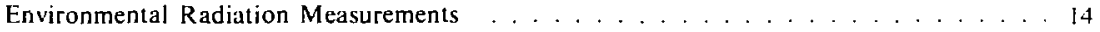

Nonradioactive Monitoring . . . . . . . . . . . . . . . . . 10

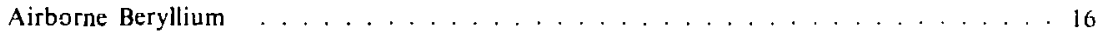

Heavy Metals Released to Livermore Sanitary Sewer . . . . . . . . . . . . . . . 17

Physical and Chemical A nalysis of LLL and Site 300 Sewage . . . . . . . . . . 17

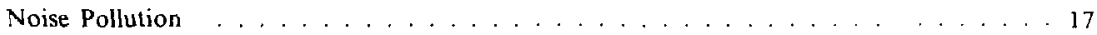

Pesticide Monitoring ... . . . . . . . . . . . . . . . . . 17

Environmental Impact of LLL Operations . . . . . . . . . . . . . . . . . . Is

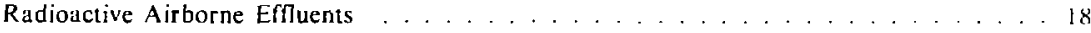

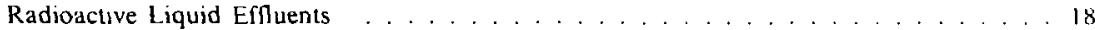

Quality Assurance . . . . . . . . . . . . . . . . . . . . . 19

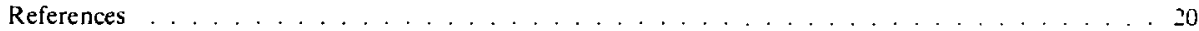

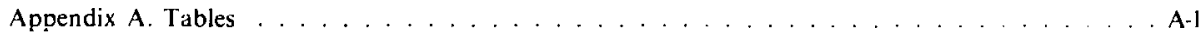

Appendix B. Discharge Limits to the Sanitary Sewer System of the City of Livermore . . . . . . . . . . . . . . . . . . . . . B-I

Appendix C. Environmental Activity Concentration-Guide Levels . . . . . . . . . . . . . . . C.1

Appendix D. Sampling and Analytical Procedures for Environmental Monitoring . . . . . . . . . . . . . . . . D.1

Appendix E. Method of Dose Calculations . . . . . . . . . . . . . . . . . . . . . . $1:-1$ 


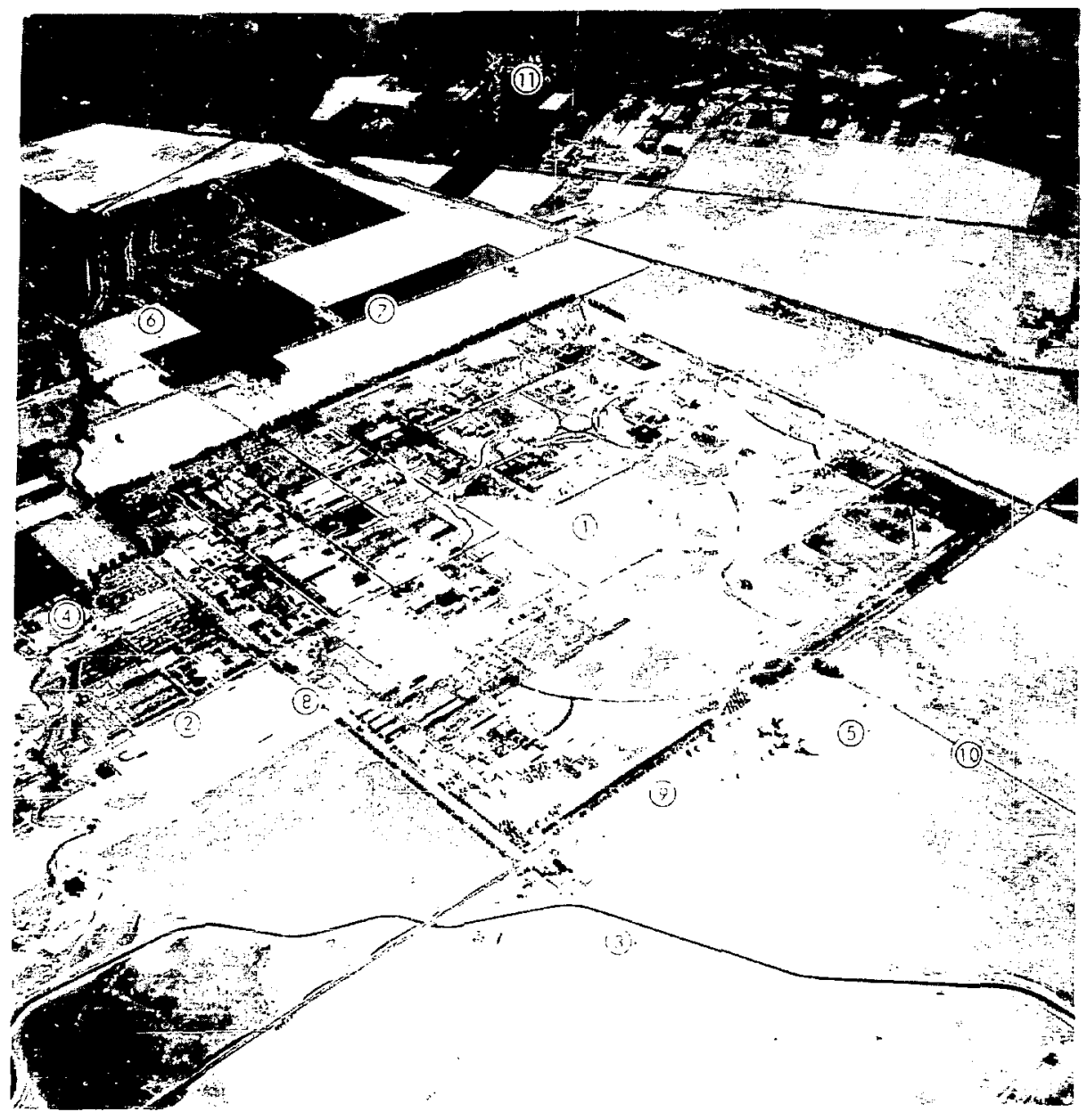

Frontispiece. Lawrence Livermore Laboratory flooking from southeast).

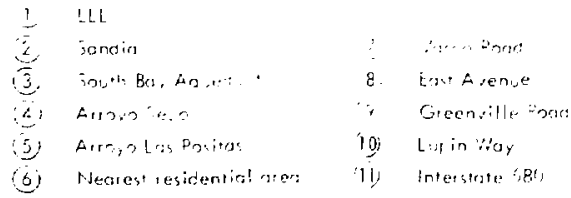




\section{Environmental monitoring at the Lawrence Livermore Laboratory 1979 Annual Report}

\section{INTRODUCTION}

The ! awrence Livernore Laboratory (LLL) is located abo.st $64 \mathrm{~km}$ easl o. San Francisco. California in the Livermore Valley of Southern Alameda County. approximately $5 \mathrm{~km}$ east of the city of livermore. The site. whici is $180 \mathrm{~m}$ above sea level. recupies a $2.54-\mathrm{km}^{2}$ area surrounded by open agricultural areas on the north. east. west, and part of the south side. Sandia Laboratories I ivernore. occupies a portion of the adjoining property on the south. and the nearest residential area is $0.8 \mathrm{~km}$ from the Laboratory's west perimeter. Of the nearly 4.8 million people ( $\mathrm{Fig}$. i) who live within $80 \mathrm{~km}$ of the Laboratory. 50.000 live in Livermore.

Established in 1952. the Laboratory is operated for the Department of Energy (DOE) by the University of California and currently employs approximately 7100 people. Although the research and development of nuclear weapons has always been the primary mission of LLL. additional programs include biomedical studies and both magnetic lusion and laser-fusion research. Programs to develop nonnuclear energy technologies have also iunl established.

Much of the Laboratory's materials test ing and high-explosives diagnostic work is conducte' at Site $300.16 \mathrm{~km}$ southeast of Livermore. At an revation of approximately $375 \mathrm{~m}$ in the sparsely populated hills of the Diablo Range. Site 300 covers an area of $27 \mathrm{~km}^{2}$.

The Livermore Valley has a climate characterized by mild. rainy winters and warm, dry summers. Annual rainfall averages about $360 \mathrm{~mm}$. and rains orcur predominantly between November and April, usually in connection with Pacific storms. Rainfall for the 1978-1979 season (July I. i978 through Junt 30, 1979) was $301 \mathrm{~mm}$ : rainfill for the 1977-78 season was $448 \mathrm{~mm}$, considerably above average. During the two drought periods. 1975-76 and 1976-77. rainfall totals were 138 and $196 \mathrm{~mm}$. respectively. Surface water drainage from the Valley is from east to west through various arrogon with the outfall near Sunol in the southwest corner of the Valley. Prevailing winds are from the west and southwest during April through Seplember. During the remainder of the vear. wind dircolions are variable. as shown by the windrose pattern in Fig. 2

The livermore ste is situaled on at north. westerly sloping alluvial flood plain bordering the lon hills of the Livermore L plands to the south The lithology of the area consists of a veries of un. consolidated marine and continental sedimentary units such as sandstones, gratiels, sllts, and clays overlaying the interbedded sandstones of the tranciscan formation. The hilly terrain surrounding the Valley is used for cutlle and sheep pasture, and the principral agricultural products in the veinity are grapes and wome. cattle. and poultry.

Water bodies adjacent to the lathoratory include the South Bay Ayueducl. which runs from the northeast to southwest. $1.8 \mathrm{~km}$ to the southeast: the Patterson Pass water treatment lacility. about $2 \mathrm{~km}$ east of l.LL: and frick lake. $+\mathrm{km}$ north of I I 1 . which is dry most of the year. Squalic recreation (boating. lishing. and suimming) is availabic at lake Del Valle. about $8 \mathrm{~km}$ south of $1 . \mathrm{Ll}$.. and at the Shatow Cliffs Recreation Area. $11 \mathrm{~km}$ to the west.

The Laborators normally receives all its treated water from the Hetch Hetchy Aqueduct (which supplies San Francisco) located $11 \mathrm{~km}$ southwest of livermore. I.aboratory storm water is channeled through atorm sewers designed to acconmodate a 10-year flom Open ditches are used in undeveloped areas of the site. Two arroy os (See Fron(ispiece) traverse LLl: Arroyo Seco at the southwest corner and Arroyo Las Positas, which originally crossed the northeast section of the site. However, in 1965, as part of an erosion control program. Arroyo Las Positas was channeled north to the northeast corner of the site. and then west 


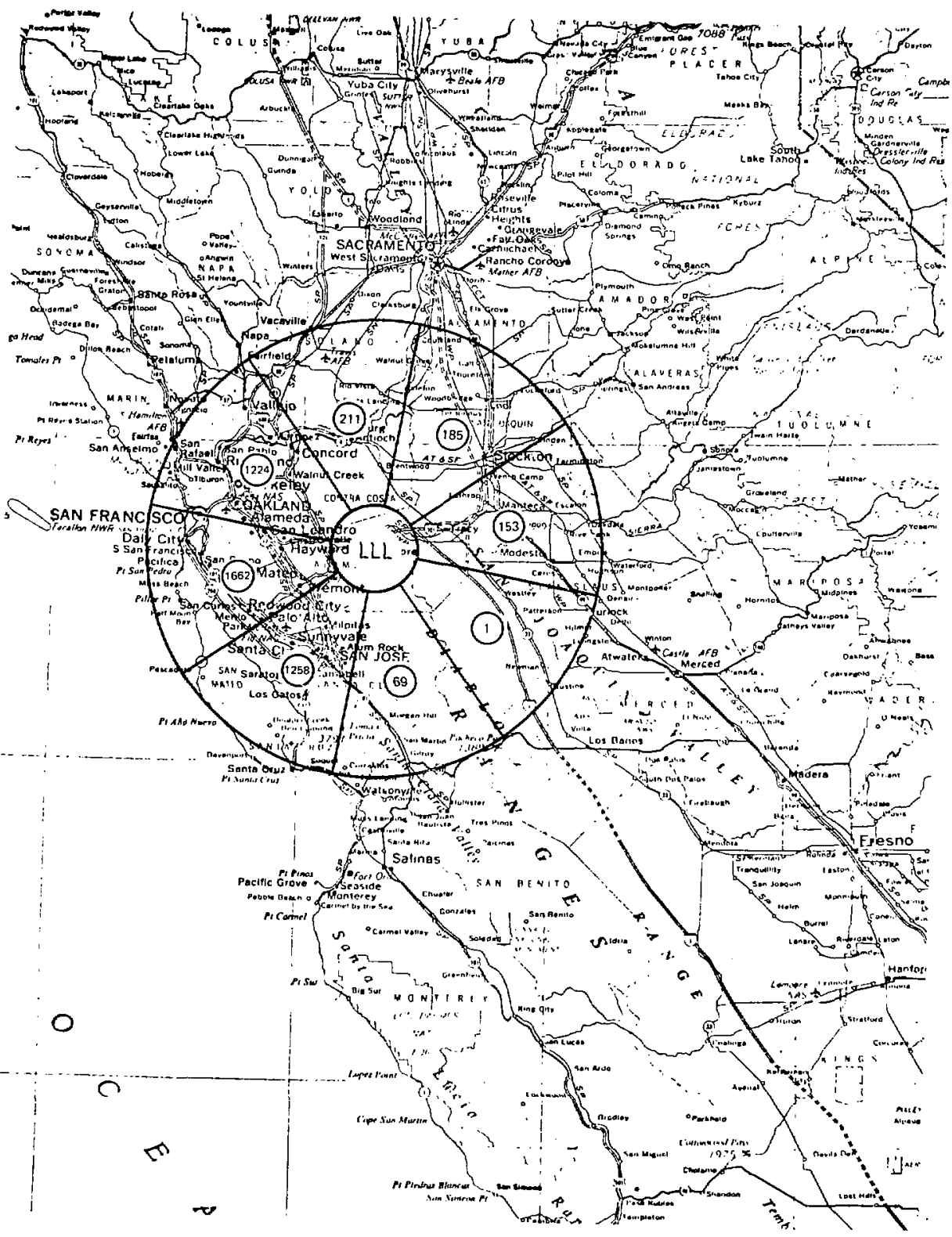

FIG. 1. Estimated population distribution by sectors within $80 \mathrm{~km}$ of Livermore. 


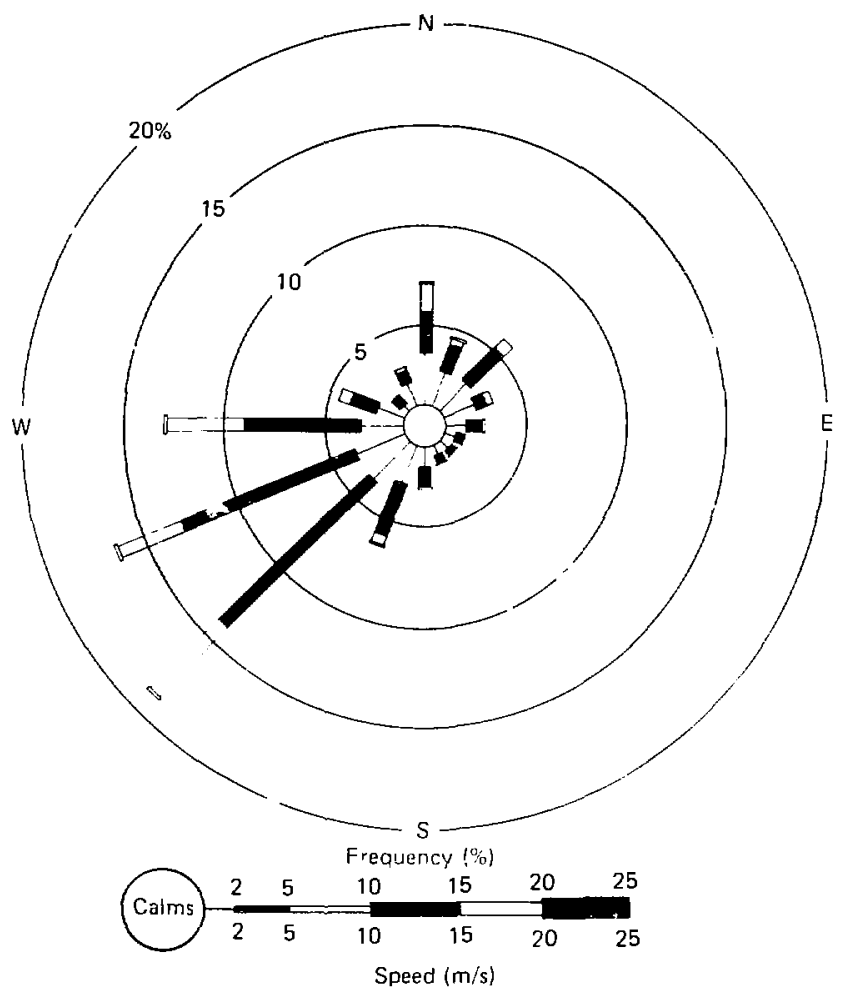

Wind direction frequency $(\%)$ Livermore 1979.

Month N NNE NE ENE E ESE SE SSE S SSW SW WSW $W$ WNW NW NNW CALM

$\begin{array}{lrllllllllllllllll}\text { January } & 9.7 & 5.5 & 8.3 & 5.8 & 5.1 & 3.2 & 3.5 & 2.3 & 3.3 & 3.8 & 12.5 & 8.7 & 7.6 & 3.5 & 3.4 & 6.8 & 7.0 \\ \text { February } & 5.5 & 6.9 & 5.7 & 4.4 & 4.2 & 3.3 & 2.9 & 3.2 & 5.0 & 9.5 & 14.1 & 11.8 & 7.3 & 3.5 & 1.7 & 3.0 & 7.9 \\ \text { March } & 5.5 & 5.7 & 7.5 & 3.8 & 4.1 & 2.5 & 1.6 & 2.5 & 3.7 & 7.5 & 14.8 & 10.8 & 12.0 & 6.6 & 2.3 & 2.8 & 6.3 \\ \text { April } & 2.8 & 2.2 & 3.4 & 2.1 & 1.6 & 1.5 & 1.2 & 1.3 & 2.5 & 7.8 & 24.5 & 16.6 & 15.2 & 8.0 & 2.3 & 2.0 & 5.0 \\ \text { May } & 6.7 & 2.3 & 1.1 & 0.8 & 1.0 & 0.7 & 0.8 & 0.6 & 1.7 & 3.9 & 20.6 & 19.9 & 22.2 & 7.4 & 2.1 & 3.6 & 4.6 \\ \text { June } & 8.7 & 2.7 & 1.3 & 1.0 & 0.6 & 0.3 & 0.6 & 0.6 & 2.1 & 5.1 & 21.8 & 20.5 & 15.7 & 4.5 & 2.1 & 5.1 & 7.2 \\ \text { July } & 2.4 & 1.3 & 1.7 & 0 & 0 & 0 & 0 & 0.2 & 1.3 & 4.7 & 31.3 & 27.2 & 22.5 & 2.8 & 0.7 & 0.8 & 2.7 \\ \text { August } & 0.5 & 0.3 & 0 & 0.3 & 0 & 0 & 0.2 & 0.3 & 1.1 & 5.8 & 37.9 & 28.6 & 19.1 & 2.7 & 0.9 & 0.5 & 1.3 \\ \text { September } & 4.5 & 5.6 & 4.2 & 1.9 & 1.4 & 1.2 & 1.3 & 1.1 & 2.6 & 5.9 & 18.5 & 21.0 & 15.9 & 4.6 & 1.4 & 2.4 & 6.5 \\ \text { October } & 5.2 & 3.3 & 5.2 & 2.6 & 1.6 & 1.2 & 1.3 & 2.2 & 3.8 & 8.3 & 17.4 & 18.1 & 11.0 & 4.5 & 2.2 & 2.6 & 9.7 \\ \text { November } & 4.8 & 9.9 & 15.8 & 9.0 & 6.8 & 3.5 & 2.1 & 2.6 & 3.7 & 5.6 & 9.3 & 6.1 & 3.6 & 1.7 & 2.2 & 3.7 & 9.6 \\ \text { December } & 27.8 & 6.8 & 11.9 & 6.9 & 6.0 & 3.4 & 1.9 & 2.3 & 3.4 & 3.4 & 4.7 & 3.6 & 2.2 & 1.9 & 2.4 & 3.9 & 7.6 \\ \text { Annual average } & 7.0 & 4.4 & 5.4 & 3.2 & 2.7 & 1.7 & 1.5 & 1.6 & 2.9 & 5.9 & 19.0 & 16.1 & 12.9 & 4.3 & 2.1 & 3.1 & 6.3\end{array}$

FIG. 2. Average annual wind direction and speed pattern at Livermore during 1979. (Measurements are made at $40 \mathrm{~m}$.) 
along the north perimeter to an outlet at the northwest corner. This outlet, which also constitutes the main pathway for the Laboratory's surface drainage (storm and irrigation), runs north in a $5.7 \times 10^{-3}-\mathrm{km}^{2}$ channel to the Western Pacific tracks, then westward where it joins Arroyo Seco.

The LLL Master Site Plan calls for a smalı lake to be established in the center of the pro; '. Provisions have been made for rezouting surface water drainage from the east to fill this lake during the rainy seasun.

Groundwater is found at depths of 15 to $30 \mathrm{~m}$ below the LLL site with a gradienl indicating a generally westward flow. Because stream runoff is a major source of groundwater recharge, considerable attention is given to radiological monitoring of the arroyos draining the valley and to the ground water wells west of the Laboratory. Laboratory sewage is discharged into the City of Livermore's sanitary sewer system and processed at the Livermore Water Rerlamation Plant (LWRP).

During the dry season. most of the treated effluent from the LWRP is used for irrigating the Livermore golf course. the lawns of the Livermore airport, and neatby agricultural land (forage crops). The remainder is discharged to Arroyo Las Positas. During the wet season. most of the effluent is discharged to the arroyo.

The salt content of this effu'nt presents a problem for both local groundwater quality and that of downstream aquifers. Accordingly, as part of the Livermore-Amador Valley Wastewater Management program. a pipeline was constructed to transport wastewater out of the valley to be discharged into the San Francisco Bay. The LWR.P was connected to this pipeline in February 1980.

A strict effuent control prossram that places maximum emphasis on controlling effluents at the source has been in effect since the Laboratory began operation. An environmental monitoring program is maintained to: (1) evaluate the effectiveness of these control measures, (2) document whether ef- fluents from the Laboratory and Site 300 operations are within applicable standards, and (3) determine the impact of these operations on the environment. Sensitive monitoring equipment is used that can detec radioactive and norradioactive pollutants well below environmental hackground levels. The program also includes the collection and analysis of air, soil, water, LLL and LWRP sewer effuents, vegetation, and milk samples. Environnental background radiation is measured all numerous locations in the vicinity of the Laboratory using gamma and neulron dosimeters.

Each spring. the Laboratory submits a report containing the results of environmental monitoring for the previous year. This report is prepared in comp'iance with the DOF: Manual Chapter 0513. "Eflluent and Environmental Monitoring and Reporting" (DOE MC 0513). Significant changes in eitiver the scope of the program or the levels of efMuents ise noted.

Appendix $A$ is a tabulution of 1979 environmental monitoring data. Because the earthquake of January 24. 1980 damaged Laboratory equipment used in some of the analyses, some of the samples collected in late 1979 could not be analyzed in time to be included in this report. Graphics have been used in the body of the report to aid in interpretation. When appropriate the tabulated data contain maximum. minimum. and average values. Error limits. when accompanying these dati. reflect uncertainties in the analyses at the $95 \%$ confidence level. Unless otherwise stated. the minimum detection limit of these measurements is assumed to have been reached when the $2 \sigma$ error is $\pm 100 \%$. In the case of radioactivity measurements. an attempt has been made to assess the potential impact from observed environmenk: levels of artificially produced radionuclides. This assessment is made by calculating the whole-body or critical-organ doses dislivered to man and comparing these with the much larger radiation dose received locally from natural sources

\section{SUMMARY}

In 1979, the annual average airborne gross heta activity in Livermore Valley air samples was $2.6 \times$
$10^{-14} \mu \mathrm{Ci} / \mathrm{ml}$, or less than half the average observed in 1978. There were no atmospheric nuclear shot: in 
1979: therefore. fission products seer in the January air filters are probably a result of residual activity from the December 14. 1978 nuclear test in China. Airborne ${ }^{238} \mathrm{U}$ concentrations at Site 300 were higher than those at Livermore because of the "depleted" uranium (a byproduct of ${ }^{235} \mathrm{U}$ enrichment) used in high-explosive tests at the Site. However. these concentrations were well below the standards set by DOE. The average annual beryllium concentrations were less than $1 \%$ of the appropriate standard at onth the Laboratory perimeter and Site 300.

Water samples collected in the Liverrıore Valley and at Site 300 exhibit gross beta and tritium activities within the ranges previously observed in these areas. One well-water sample from Site 300 shows an above-average level of gross alpha activity. This activity has been found to be naturally occuiring uranium at concentrations well within those specified in DOE MC 0524.

$T$ ritium analyses were made on well-water samples collected near the Livermore Water Reclamation Plant (LWRP). These analyses. begun in 1977. were made to determine the extent to which low levels of tritium in the LWRP effluent may be migrating into ground water. As was found during the 1977 and 1978 surveys. the highest tritium values were detected in wells west of the plant near Arroyo Las Positas: however all concentrations were well below the standards set by DOE.

Tritium levels found in the Livermore Valley and Site 300 vegetation were also comparable to those observed in 1978. As a means of evaluating the possible impact of Laboratory effluents on locally grown foodstuff, the tritium content of Livermore Valley wines was compared with values from other California and European wints. The tritium levels in L.ivermore Valley wines were found to be within the range in both European wines and surface waters throughout the world and someivhat higher than those in California wines. Honey produced in the Livermore Valley contained tritium levels between the levels in Valley surface water and vegetation.

For 1979, the median an nual gamma-radiation dose al the Laboratory perimeter was 61 mrem, and the median off-sile background dose was 59 mrem. The difference between these values is not staristically significant. A 14-MeV neutron generator near the south perimeler continued to be a source of elevated radiation. However, by performing many of the high-flux experiments at the rew rotaling target neutron source facility (Building 292). the radiation dose rates at the Laborators south perimeter were reduced well helow DOE standirds.

Assessments of the calculated radiation dose to an individual from the environmental concentrations listed in this report demonstrates that the dose contribution from Laboratory operations in 1979 was small compared with the dose received locally from natural sources.

\section{MONITORING DATA-COLLECTION, ANALYSIS, AND EVALUATION}

\section{RADIOACTIVE MONITORING}

\author{
Airborne Radioactivity \\ Concentrations of various airborne radio- \\ nuclides are measured at Laboratory perimeters, at \\ off-site locations near the Laboratory, and at \\ Site 300. Sampling locations are shown in Figs. 3 \\ through 6 . The 6 samplers on the Laboratory \\ perimeter and the 10 samplers at Site 300 use
}

$5.2 \times 10^{-2}-\mathrm{m}^{2}$ Whatman-4l cellulose filters. These samplers are operated at an average flow rate of 700 litres/min. Laboratory perimeter and Site 300 air filters are also analyzed for beryllium as part of the Laboratory's nonradioactive monitoring program. An easily dissolved filter and a low trace-metal background are requirements for these analyses. Whatman $4 \mathrm{l}$ represents a balance between such requirements and particulate collection efficiency. ${ }^{1}$ Off-site samplers throughout the Livermore Valley 


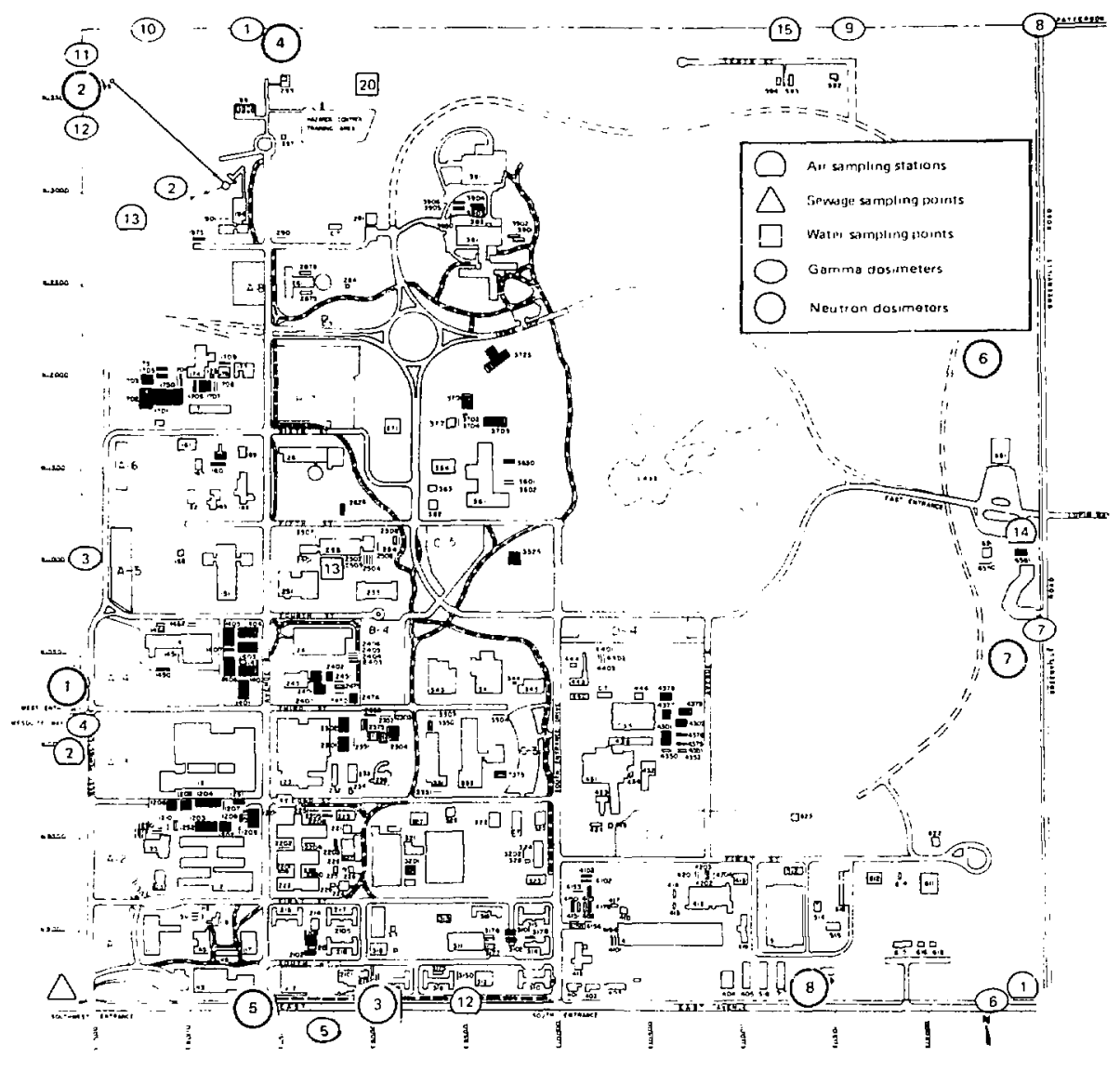

FIG. 3. LLL on-site environment al sampling locations.

use $4.56 \times 10^{-3}-\mathrm{m}^{2}$ glass-fiber filters (Flanders $\mathrm{F}$ 700 ) and are operated at a flow rate of $80 \mathrm{litres} / \mathrm{min}$. Al] air filters are changed weekly. Perimeter and Site. 300 filters are cut in half, and half of each filter is ratained for beryllium analysis (see "Nonradioactive Monitoring").

After a four-day delay for decay of the radonthoron daughters, gross alpha and beta activities on the filters are determined with an automatic gasflow proportional counter. Monthly composites of Laboratory perimeter and Site 300 filters are also counted for specific gamma-s-mitting radionuclides using a $\mathrm{Ge}(\mathrm{Li})$ detector equipped with Comptor suppression.2 Following gamma counting. the Laboratory's perimeter filters are grouped by sampling locations. These individual samples and the Site 300 composites are analyzed for the presence of ${ }^{239} \mathrm{Pu},{ }^{238} \mathrm{Pu},{ }^{137} \mathrm{Cs},{ }^{235} \mathrm{U}$, and ${ }^{2.38} \mathrm{U}$.

Tables 1 and 2 in Appendix A show airborne gross alpha and gross beta activities for the Livermore Valley samples, and Tables 3 and 4 show corresponding activities for Site 300.

Average annual gross beta activity in both Livermore and Site 300 air samples was less than 


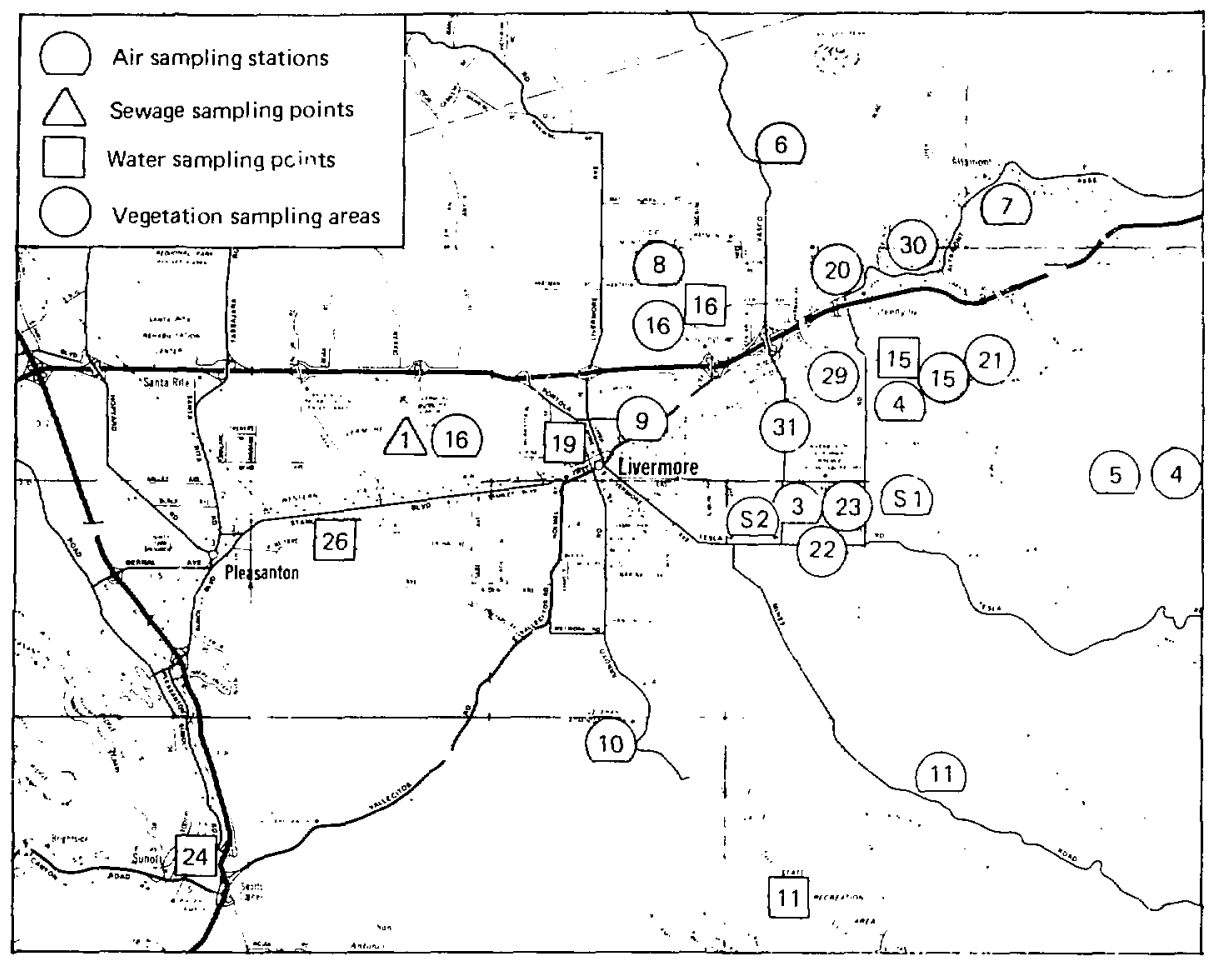

FIG. 4. I.LL off-site environmental sampling locations.

half that observed during $1978 .{ }^{3}$ There were no atmospheric nuclear shots in 1979. Tables 5 and 6 list the activities of the more abundant gammi-emitting radionuclides that contribute to the beta activity in Livermore and Site 300 samples. The fission products seen on the January air filters, which were below the limit of sensitivity during the remainder of the year. may be a result of subsequent passes of debıis from the Decembei 14, 1978 nuclear shot by the Chinese. Table 7 shows the concentration of plutonium in dir thier samnles collected in the Livermore Valley. Tables 3 and 9 show the concentrations of airborne ${ }^{239} \mathrm{Pu},{ }^{137} \mathrm{Cs},{ }^{235} \mathrm{U}$. and ${ }^{238} \mathrm{U}$ in Livermore perimeter and Site 300 air samples. The higher concentration of ${ }^{238} \mathrm{U}$ at Site 300 is a result of the "depleted" uranium ia byproduct of ${ }^{235} \mathrm{U}$ enrichment) used at the Site. As noted, however, the uranium concentrations are well below the concentration guides (CG) in DOE MC 0524.
Concentrations of airborne tritiated water (HTO) were determined for each of the LIL perimeter air-sampling locations shown in Fig. 3 and at two off-ste locations (SI and S2 in Fig. 4). Water vapor was collected on silica-gel samplers that operaled at a flow rate of about 0.5 litres $/ \mathrm{min}$ for a two-week period. The collected water was recovered by vacuum drying the silica gel at $150^{\circ} \mathrm{C}$. and the HTO wa measured by liquid scintillation counting. Tatne 10 shows average monthly HTO concentrations observed at each sampling location with an overall average annual concentration of 4.0 $\times 10^{-11} \mu \mathrm{Ci} / \mathrm{ml}$. The highest HTO concentration was observed at the west site boundary. Location 13. during January. That concentration ( $1.2 \times 10^{-10}$ $\mu \mathrm{Ci} / \mathrm{ml}$ is less than 1,10 of $1 \%$ of the appropriate standard.

As noted, winds during the late fall and winter are quite variable. Therefore, Location 12 shows the 


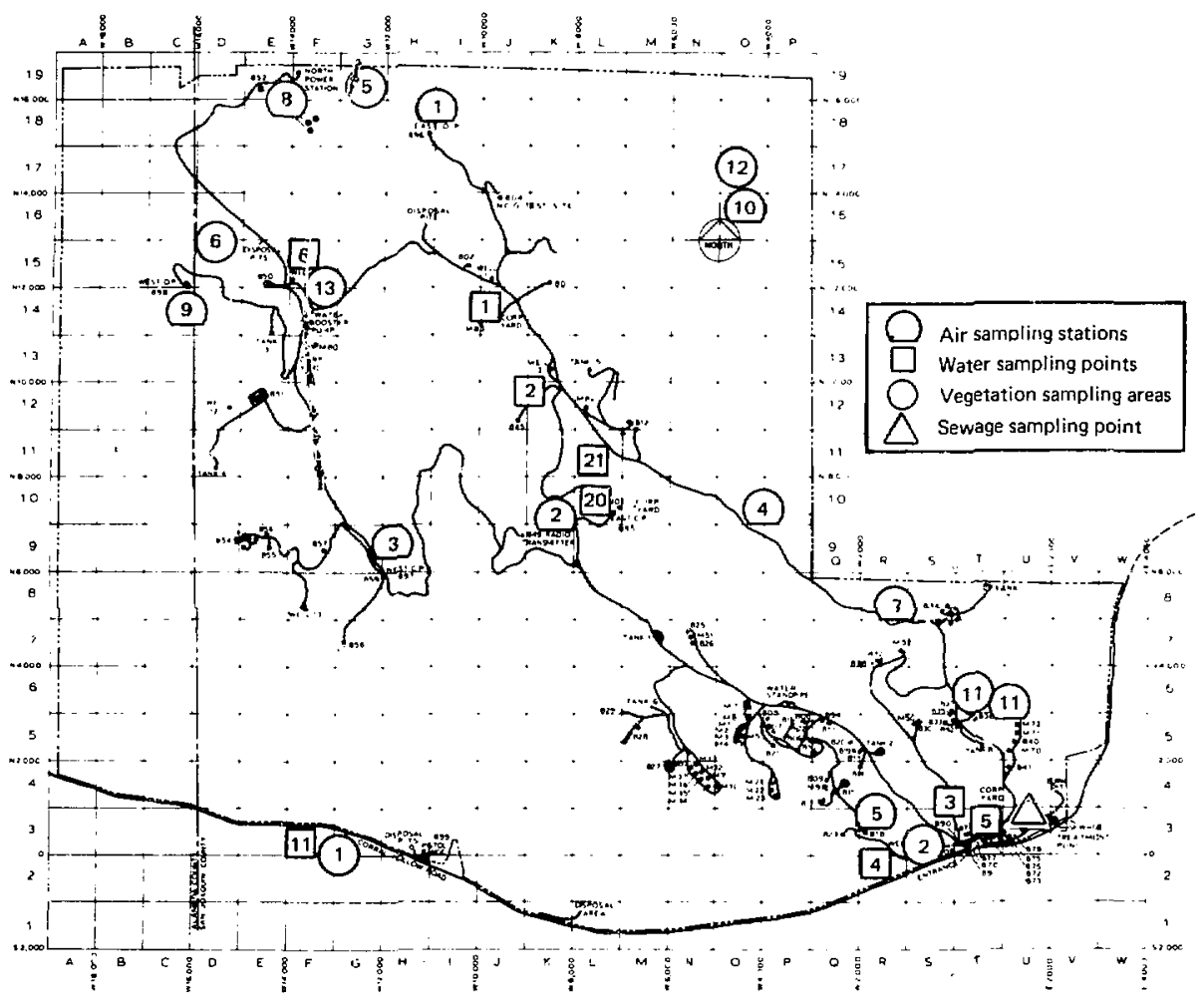

FIG. 5. Site 300 on-site environmental sampling locations.

highest annual average concentration, probably because this location is so close to one of the tritium effluent sources (the $14-\mathrm{MeV}$ neutron generator) and because it is downwind from this facility most of the year. The average annual HTO concentration at Location 12 is about $40 \%$ lower than that obsarved in 1978. This reduction is a result of the transfer of many of the high-flux experiments to Building 292, located in the northwest quadrant of the Laboratory.

\section{Radioactivity in Soil}

An intensive soll-sampling program conducted in 1971 and 1972 provides a data base for the concentration range of various radionuclides in soil near the Laboratory and at Site 300. Since 1972, soil sampling in the vicinity of LLL and at Site 300 has been part of a continuing LLL surveillance program to document any changes in environmental levels of radioactivity that may have occurred and to evaluate any increase in radioactivity that mighr have resulted from Laboratory operations. During 1979, 26 soil samples were collected from various lncales in the Livermore Valle;. Most of these sampling locations were randonly selected from a listing of locations that were sampled during the 1971-72 program. Figure 7 shows the 1979 soilsampling location. and Fig. 8 indicates the locations at Site 300 where annual samples have been collected since 1973

All samples were collected to a depth of $5 \mathrm{~cm}$. After collection, the samples were dried, ground. and blended. Plutonium-239 content was determined in each sample following the HASL acidleaching procedure. ${ }^{+}$Table 11 lists the plutonium activities observed in samples collected within the 


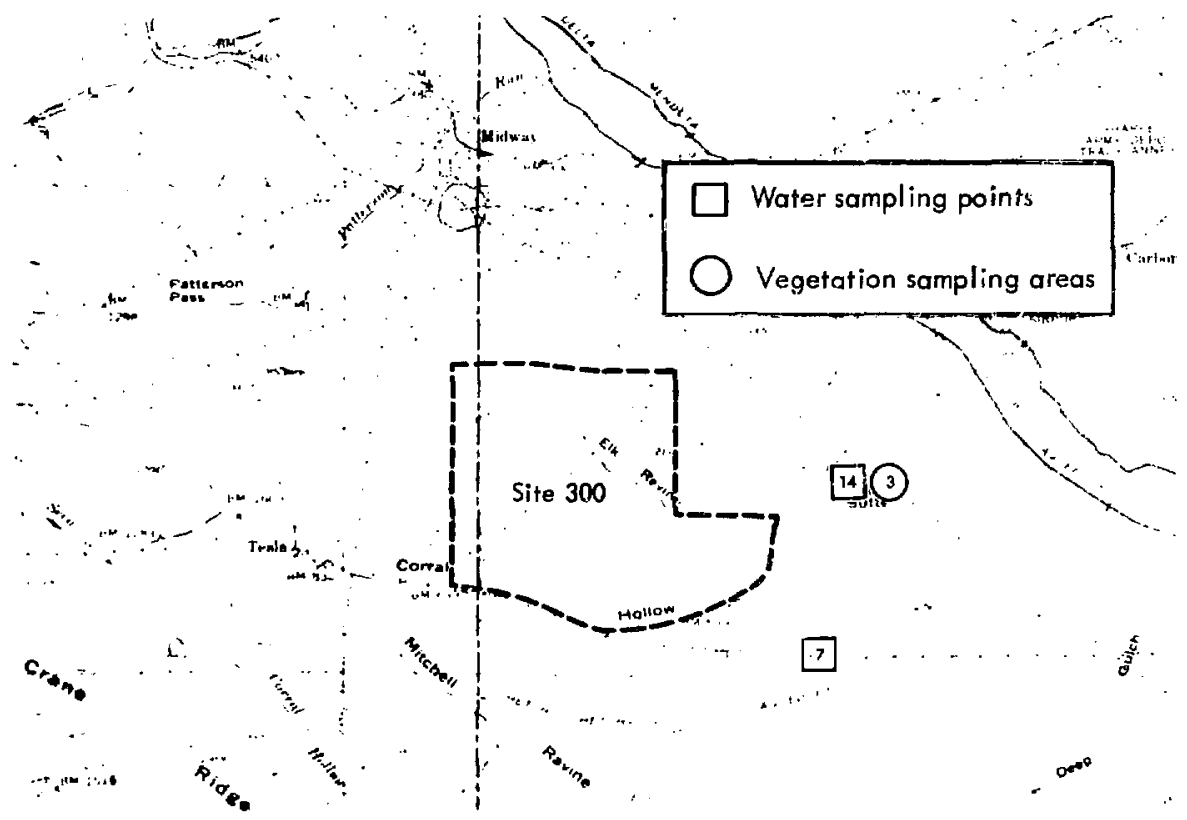

FIG. 6. Site 300 off-site enyironmental sampling locations.

Livermore Valley during 1979, and Fig. 9 is a distribution plot of these activities. Table 12 shows the plutonium activities in the Site 300 samples. There were negligible changes from those observed in previous samples collected in the same locations. ${ }^{3}$

Samples 779,780 , and 781 represent a resampling of the area where elevated plutonium was reported in 1978. "Plutonium levels in these samples, as well as in those samples collected when the area was resampled in 1978. are in the range attributable to global fallout. Sample pairs 733 and 734 , and 745 and 746 were collected in the field as replicates. while samples $730 \mathrm{~A}$. 738 A. and $746 \mathrm{~A}$ represent duplicate aliquots taken from well mixed samples. The results suzgest that most of the variability is asso " ted with sample inhomogeneity and environmental variation rather than with the radiochemical procedures. "Sample 782 in Table 12 is a resample at the location at Site 300 (See Fig. 8) where Sumple 778 was collected. Analysis of sample 782 showed the plutonium to be in the range attributable to global fallout.

For gamma-spectra analysis, approximately $300-\mathrm{g}$ aliquots of soil were sealed in $200-\mathrm{cm}^{3}$. thin- walled cans of aluminum and counted in the $\mathrm{Ge}(\mathrm{Li})$ spectrometer. 2 The results of the gamma-spectra analysis of Livermore Valley soil samples are shown in Table 11.

High-explosive tests at Site 300 often involve the use of depleted uranium. Accordingly, soil samples are taken annually to determine how these tests perturb the $235 \mathrm{U}, 23 \mathrm{H}_{\mathrm{U}}$ ratio of the soil. Isotopic uranium measurements were made with isotopic dilution mass spectrometry. As in the past. the analysis indicated that sotopic perturbation is essentially limited to areas adjacent to the firing bunkers. ${ }^{6.7}$ The isotopic uranium datid shown in Table 12 are comparable to those observed during 1978. Plutonium and ${ }^{137} \mathrm{Cs}$ levels are aiso in the range found in Site 300 soil samples collected in 1978.

\section{Radioactivity in Sewage}

Liquid radioactive wastes are treated to reduce activity levels to the lowest levels pract ole and well below standards in DOE MC 0524. After tratment. the liquid wastes are released into the city of 


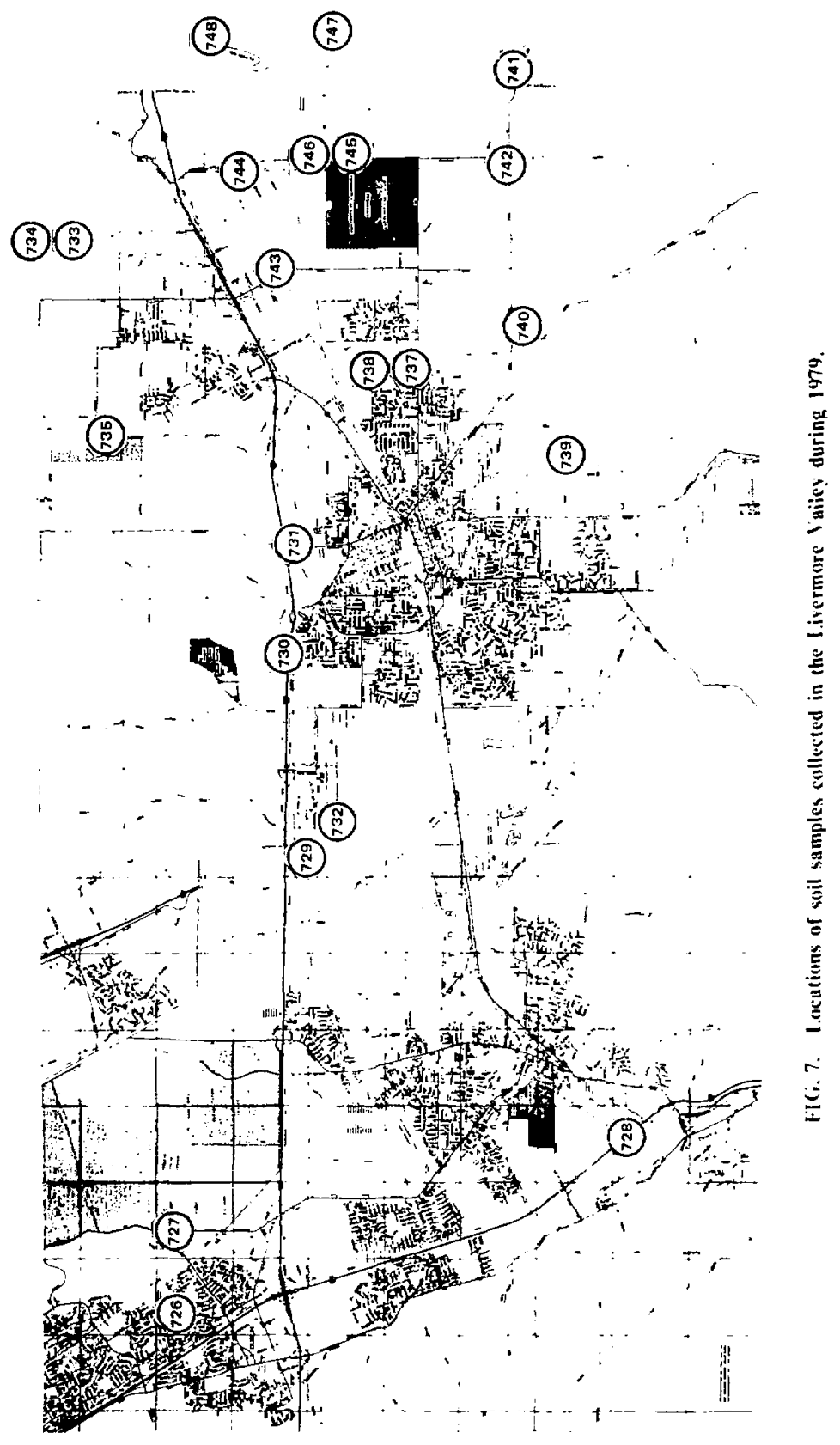




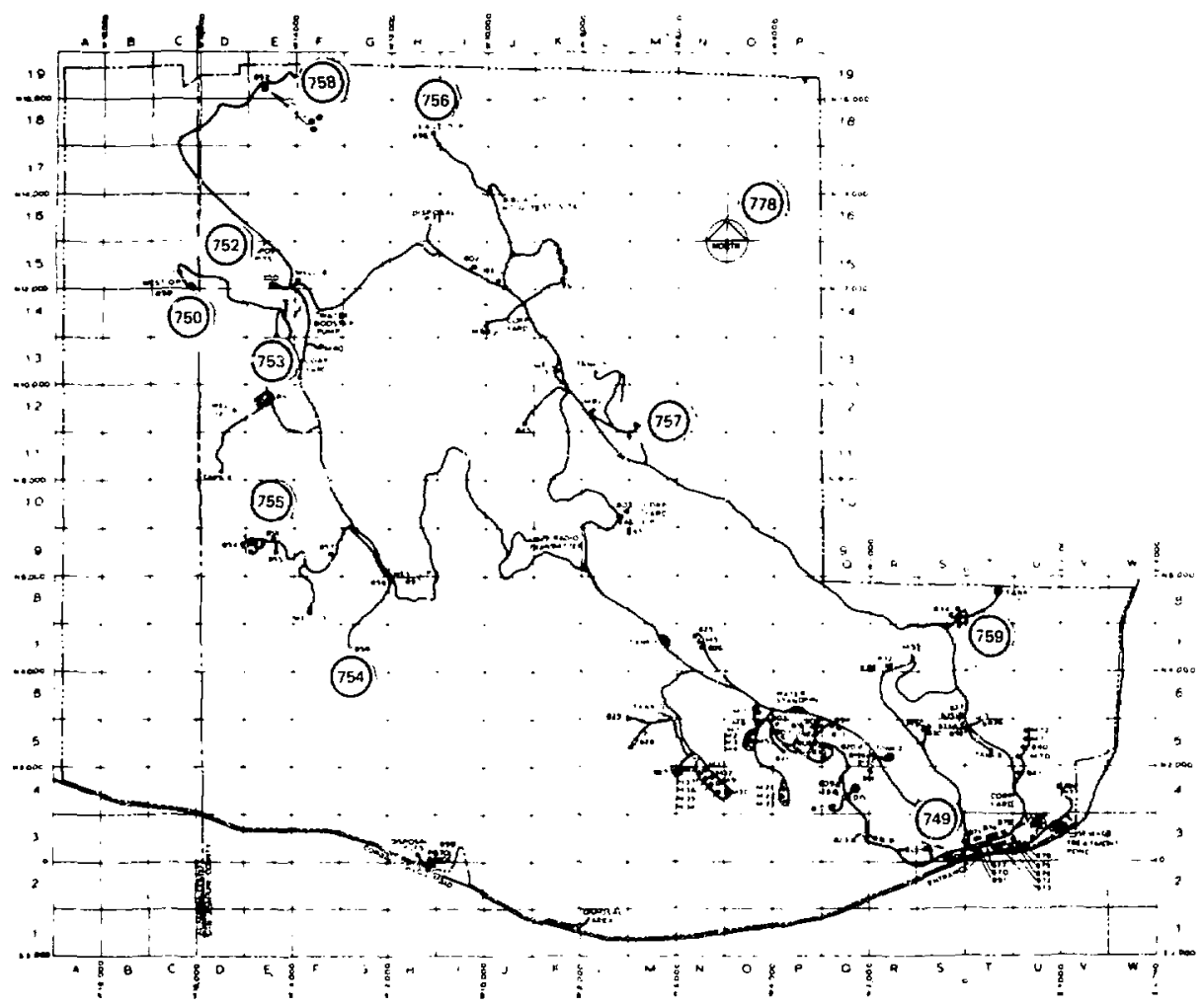

Fl(; 8 . locations of soil $5 a m$ res ce!lected inside the site .310 boundary.

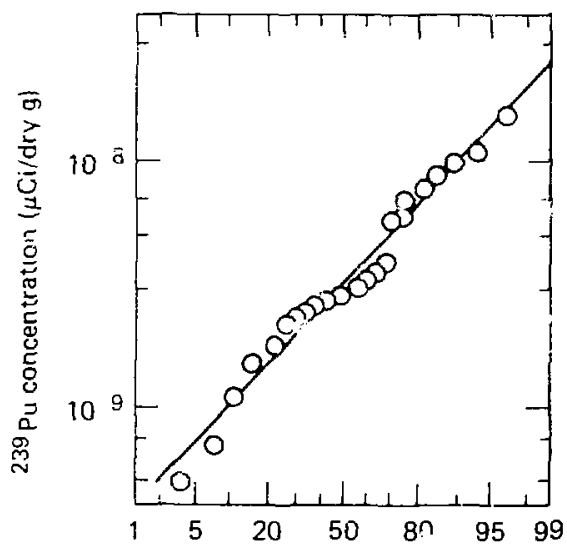

FIC. 9. Distribution plot of ${ }^{2.39} \mathrm{Pu}$ in soil semples collected in the Livermore Valley during 1979.

Cumulative frequency-less than $\langle \%\rangle$ 
Livermore's sanitary sewer system at the LLL outfall shown in Fig. 3. This effluent is continuously monitored for $\mathrm{pH}$ and radioactivity.

Liquid wastes from Livermore's sanitary sewer system are treated at the LWRP, it 200-litre is tertiary sewage-treatment plant that serves residential, commercial, and industrial water users in Livermore. After a primary settling process to remove solid matter, the liquid is passed through trickling filters. then througl, an aeration stage, and on to a final sedimentation phase. The purified sewage is then filtered through charcoal, chlorinated to kill pathogenic hacterial, and dechlorinated hefore heing released from the plant.

During the dry season. most of the treated effluent is used for irrigating the Livermore Golf Course, the lawns of the Livermore Airport. and rearby agricultural land (forage crops). The remainder of the effluent is discharged to Arroyo Las Positas. and during the wet season most of the effluent is discharged into the arroyo. The water in Arroy'o Las Positas flows into Arroyo Mocho. then into Arroyo de la Laguna, and finally into Alameda Creek. Because the LWR P effuert may contain low levels of tritium from routine LLL releases to the sanitary sewer system, tritium measurements have been made on samples collected from wells throughout the Valley, from Arroyo de la Laguna, and from aquifers in the Niles Cone area. Results of the most recent measurements are contained in this report under "Radioactivity in Water." In all cases the tritium activities are well below the DOE standards for water in uncontrolled areas.

The salt content of the treated effluent presents a problem for both local groundwater quality and that of the Niles Cone aquifers. Accordingly. as part of the Livermore-Amador Valley Wastewater Management program, a pipeline was constructed to transport wastewater out of the valley to be discharged into the San Franciscn Bay. The Livermore sewage plant was connected to this pipeline in February 1980. Although the effluent will still be used for irrigation, it will no longer be discharged into the arroyo. thus elıminating the primary means of tritium migration to local and downstream groundwater.

Samples of the liquid effluent are collected daily. Table 13 compares the activity levels of certain radionuclides in the L.LL effluent with those in the effluent from the LWRP. Plutonium levels in the LLL effluent in January are believed to be associated with the treatment of a large quantity of transuranic liquid waste during the last quarter of 1978. ${ }^{3}$ Nevertheless, all plutonium concentrations are well below DOF standards for discharge into the sanitary sewer system.

\section{Radioactivity in Water}

Water samples are collected from the various Livermore Valley and Site 300 locations shown in Figs. 3 through 6 . These samples are analyzed for gross alpha and heta activities with a gasproportional counter. Tables 14 and 15 show the gross alphal activitios in Livermore Valley and Site 300 samples, respectively. Gross betil activities for Livermore and Site 300 samples are show $n$ in Tables 16 and 17 .

Livermore sampling locations 11 , 16, and 24 (Fig. 4) are surface water sources (ponds, creeks, and reservoirs), and Location 20 (Fig. 2) is the collection site of Livermore rainfall. The other locatiuns are domestic water sources. Gross alpha and beta activities in Livermore water samples collected in 1979 were below both DOE and EPA standards for drinking sater."

Site 300 water sampies are collected from onsite wells (Fig. 4, Locations 1-7) and orf-site creeks (Locations II and 14). Location 20 is Site 300 rainwater, and Location 21 is a spring-fed pond near Bunker 812. With the exception of samples from the rainwater and two off-site creeks, al! the Site 300 samples came from deep wells and springs. Samples from Location 4 (Table 14), a well near the Site entrance, had a gross alpha level in water that exceeded the drinking water standards of DOE and EPA. Therefor. further specilic analyses were performed to identify the source of the radioactivity. No radionuclides werc found other than uranium. The uranium concentration was at a level well within that spesified in DOE MC 0524. An alpha pulse spectroscopic analysis of the uranium isotopes showed the ${ }^{234} \mathrm{U} /{ }^{238} \mathrm{U}$ aclivity ratio to be typiral of naturally oceurring uranium; thus, the source of the uranium is not "depleted uranium" used in Site 300 operations. A ${ }^{226} \mathrm{R}$ a measurement hased on radon emanation and a ${ }^{232}$ Th analysis using alpha-pulse spectroscopy showed both radionuclides to be less than $0.05 \mathrm{pCi} / \mathrm{l}$. The low ${ }^{226} \mathrm{Ra}$ and ${ }^{232} \mathrm{Th}$ activities probably result from a relatively high $\mathrm{pH}$ and high carbonate content in the water of this well. Under these conditions, radium and thorium would be expected to coprecipitate with calcium as caliche. coating the grain surfaces within the aquifer. 
Neither the EPA ${ }^{x}$ nor the State of California" specify a limit for natural uranium in drinking water. In their limit for gross alpha activity, uranium is specifically excluded from the total. It should be noted that the limit for natural uranium in water sprecified in DOE MC $0524\left(2 \times 10^{-5}\right.$ $\mu \mathrm{Ci} \mathrm{ml}\}$ is based on the fact that the chemical toxicits of uranium as a heavy metal is greater than its toxicil! as a radioactive material.

Witer sumples from the Livermore Valley ard Site 300 are anilyzed for tritium activity. Because of the lou tritium activities, it was necessary to distill and electrolyticaily enrich the samples before liquidscintillation countung. Tables 18 and 19 stow the data for the Livermore and Site 300 samples, respectively. These data indicate that the samples exhibit concentrations that are well below reicommended CG values. Tables 18 and 19 also include an estimute of the annual dose that may be delivered to an adult who consumes water containing the listed tritium concentrations. These doses, which are Iypically less than 0.1 mrem, are based on the dose conversion facto... - . in U.S. NRC Regulatory Guide 1.109.10

As noted previously, treated eflltent from the LWRP is used to irrigate nearby municipal property. During the rainy season, most of the effuent was released directly into A rroyo Las Positas. This effluent contuins low levels of tritium which come from normal LLL operational releases to the sanitary sewer system $A$ s part of a study begun in 1977.11 tritium measurements are now made annually on water samples collected from neighboring wells to determine the extent of tritium migration into ground water. Many of the wells were in the immediate vicinity of the LWRP and Arroyo Las Posilas; however, additional samples were also collected from areas some distance from the release points. Sampling locations are indicated in Fig. 10 , and the tritium data are shown in Table 20 . Thie highest tritium values appear in wells west of thi: LWRP near Arroyo Las Positas and are essentrally unchanged from the activities found in 1978 . Tritium activities in all samples were well below the guidelines for water in uncontrolled areas as stated in DOE MC 0524.

\section{Radioactivity in Vegetation and Foodstuffs}

Each month, vegetation samples (usually native grasses) are collected throughout the Livermore Valley, at Site 300 , and at off-site locations near Site 300, as shown in Figs. 3 through 5. These samples are frees-dried. and the tritium activity in the recovered water is determined by liquidscintillation counting. Table 21 shows the tritium data for vegeta'ion collected in the l.ivermore Villey. The whole-body radiation doses shown were derived using the dose conversion fictors in the U.S. NRC Regulatory Guide 1.109." assuming that the observed actisities aere lypical of those in edihle vegetation grown in the Livermure area. These potential doses arc all less than 1 mrem/y.

T:tole 22 shous the 1979 tritium datil for Sile 300 vegetation. Location 6 is adjarent to an area that contains tritudi-contaminated debris from a firing table. As a result of the seasonal rains, the tritum apparently .ntered an aquifer whose outflow is in the area where Location 13 samples are routinely collected.

Beginning in 1977, as a means of evaluating the possible impact of Laboratory effluents on locally grown foodstuff, the tritium content of Livermore Valley wines was measured and compared with that found in other Califorrial wines and European wines. "Wine samples collected in 1979 were catalytically oxidized to carbon dioxide and water, and the tritium content of the recovered water was measured by liquid scintillation. The daia in Table 23 represent a composite of 25 samples collected in 1977 and 10 samples collected in 1979. As found in 1977. the tritium levels of the Valley wines renuin within the range in both the European wines and surface waters throughout the world and surnewhat higher than thase Calsfornia wines produced from ziapes grown unissie the valiey.

Samples of honey produced from a variety uf flower sources in the Livernore Valley were analyzed for tritium content. Following the oxidation of the samples in a Parr oxygen bomb, the tritium content of the water produced was determined by liquid scintillation. The data in Table 24 show that the tritium content of these honey samples ranges between the levels found in Livermore Valley surface water and vegetation in the vicinity of the Laboratory. Thus, there appears to be no concentration of tritium activity through this food chain.

\section{Radioactivity in Milk}

During 1979, goat milk samples were obtained from several farms within about $5 \mathrm{~km}$ of the Laboratory. Before analysis, the samples were oven 


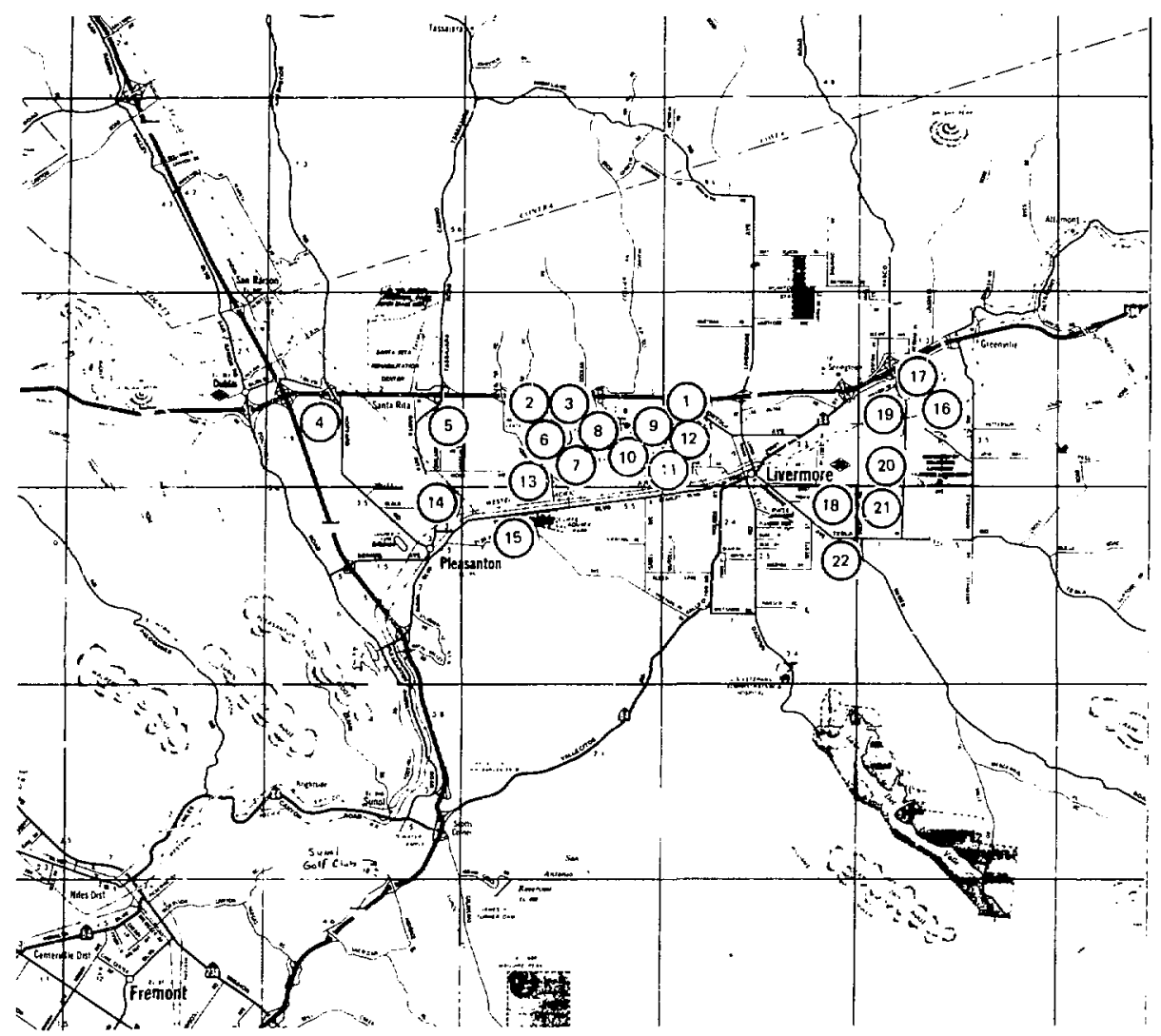

FIG. 10. Location of groundwater samples collected in the Livermore Valley during 1978.

dried and the resultant concentrates gamma counted in a $\mathrm{Ge}(\mathrm{Li})$ system. Each vacuum-distilled sample was then analyzed for tritium activity by liquidscintillation counting. The activities of the ${ }^{137} \mathrm{Cs}$, ${ }^{40} \mathrm{~K}$, and ${ }^{3} \mathrm{H}$ in the samples are shown in Table 25 . Also shown are the calculated annual whole-body or critical-organ radiation doses that could be received from consuming this milk. These calculations are based on a milk intake of 310 litres/yr and on the models previously referenced. The only dose to an individual above $1 \mathrm{mrem}$ is from naturally occurring ${ }^{40} \mathrm{~K}$.

\section{Environmencal Radiation \\ Measurements}

Quarterly, environmental radiation is measured at the $12 \mathrm{LLL}$ perimeter locations (Fig. 3) and at the 41 off-site locations (Fig. 11). These measurements are obtained with thermoluminescence dosimeters using a previously pubished procedure. ${ }^{12}$ Based on past measurements, ${ }^{13}$ environmental terrestrial exposure rates in the Livermore Valley vary from 3 to $7 \mu \mathrm{R} / \mathrm{h}$. Cosmic radiation. calculated from the local elevation and geomagnetic latitude according to the data of Lowder and Beck, ${ }^{14}$ is approximately $4 \mu \mathrm{R} / \mathrm{h}$.

Table 26 shows quarterly and annual radiation doses (in mrem) derived from measured exposure rates at perimeter locations. The operation of a 14 MeV neutron generator adjacent to the south boundary fence was responsible for elevated dose rates at Location 5 on the south site boundary directly opposite this facility. However, these dose 


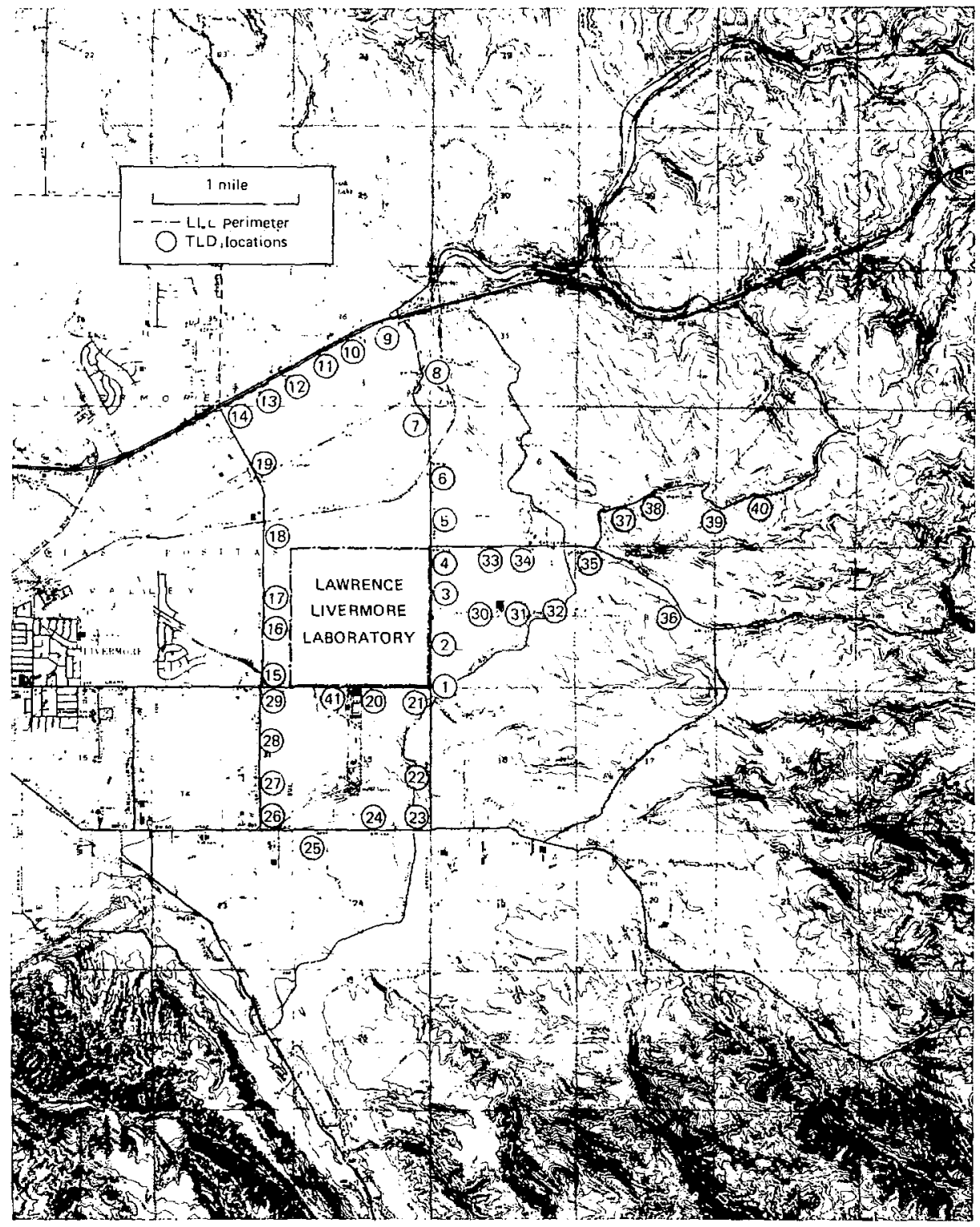

FIG. 11. Location of TLDs in the vicinity of LLL. 
rates are lower than those observed during 1978 because many high-flux experiments normally performed at this location are now being performed in Bldg. 292 in the northwest quadrant of the Laboratory.

The median annual off-site dose rate of 59 mrem (Fig. 12) is identical to that observed in 1978. Although the median annual perimeter dose rate of 61 mrem is slightly lower than the 64 mrem of 1978 , this difference is not considered statistically significant. Locations 10,11, and 12 are near a lincar accelerator facility. Figure 12 shows the 1978 annual frequency distribution of environmental dose rates observed at the 41 off-site locations. The dosimeter that recorded the highest dose (92 mrem) was near an off-site industrial plant where rudiography is frequently performed. Figure 13 is a dose-distribution plot combining Laboratory perimeter and off-site measurements. Doses above those typical of environmental background have betn identified in the comments above or are noted in Table 26.

Environmental neutron dose-rate measurements are also made at eight locations on the LLL site perimeter using ${ }^{235} \mathrm{U}$ track-etch detecto:" A detailed description of the detector and the sparkcounting procedure has been published. ${ }^{15}$ Neutron monitoring locations are shown in Fig. 3. With the exception of Location 3, all levels are within the range typical of natural background (12 mrem). Location 3 monitors the ICT, and the elevated dose, 180 mrem, is a result of operations conducted within this facility.

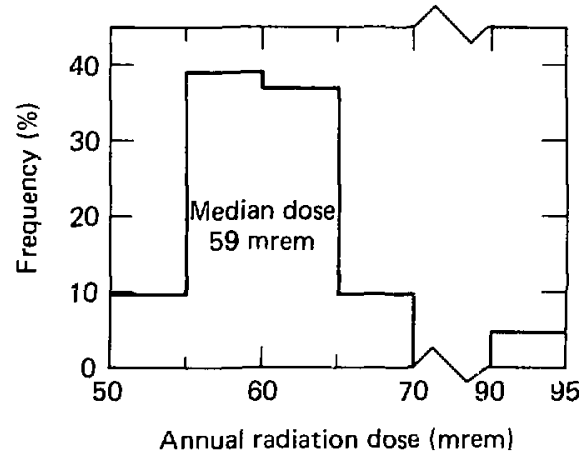

FIG. 12. Annual off-site gamma radiation background for 1979 .

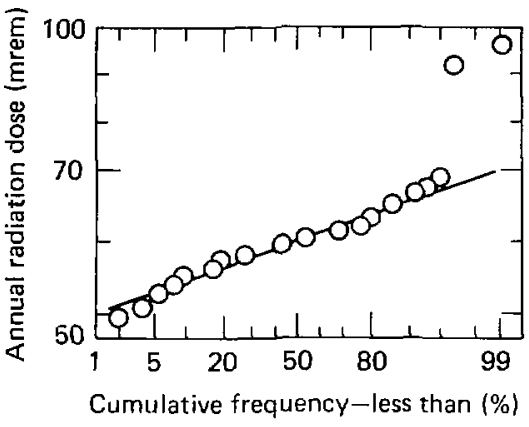

FIG. 13. TLD dose-distributions plot for the LLL perimeter and Lirermore Valley during 1979.

\section{NONRADIOACTIVE MONITORING}

\section{Airborne Beryllium}

Beryllium monitoring of air both in-plant and at or near LLL property boundaries has always been a part of the Laboratory's sitfety program. Monthly, half of every filter from the LLL perimeter and Site 300 is composited by sampling location and then wet digested. Next, the beryllium content of the solutions is determined by atomic absorption analysis.

Tables 27 and 28 show average monthly concentrations of airborn beryllium for LLL perimeter and Site 300 sampling locations, respectively. There appear to be no differences between the levels at Site 300 , where beryllium is frequently expended in highexplosive experiments, and those observed at Livermore. The concentrations, which are two to three arders of magnitude below the emission standard, can be accounted for by the resuspension of surface soil containing naturally occurring beryllium. Local soils contain approximately $1 \mathrm{ppm}$ of beryllium, and Livermore's air typically contains $10-100 \mathrm{~g}$ of particulates per cubic metre. By using a value of 50 $\mu \mathrm{g} / \mathrm{m}^{3}$ for an average dust load and $1 \mathrm{ppm}$ for beryllium content of this dust, an airborne beryllium concentration of $5.0 \times 10^{-5} \mu \mathrm{g} / \mathrm{m}^{3} \mathrm{can}$ be calculated. This value is in good agrcement with the data in Tables 27 and 28. These concentrations are plotted in Figs 14 and 15. Average annual concentrations are less than $1 \%$ of the appropriate standard. 


\section{Heavy Metals Released to}

Livermore Sanitary Sewer

As noted previously, sanitary sewage from the Laboratory is treated at the LWRP, a 200-litre/s tertiary sewage-treatment plant serving residential, commercial, and industrial users in Livermore. This effluent is continuously monitored for $\mathrm{pH}$ and radioactivity before it enters the Livermore sewer system. ${ }^{12}$ Monthly, sewage samples representative of daily flow are collected and composited, and the composites analyzed for the metals shown in Table 29.

\section{Physical and Chemicai Analysis of LLL and Site 300 Sewage}

Simpies of Laboratory sewage effluent are collected quarterly. These samples a re subjected to a variety of analyses, including biochemical oxygen demand, ammonia, nitrate, total nitrogen content, alkaiinity. and total solids. Table 30 shows the datia for 1973. and Table 31 shows results obtained on similar quarterly samples collected from the oxidation pond at Site 300 .

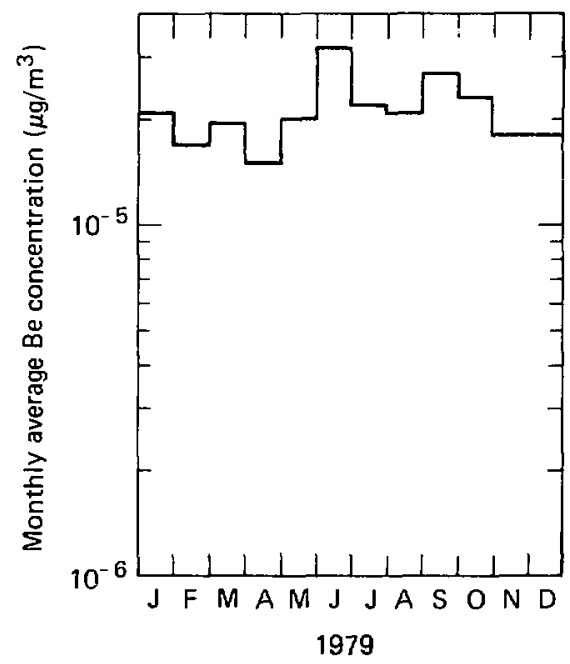

FIG. 14. Beryllium concentration in LI.L, perimeter air filters during 1979.

\section{Noise Pollution}

As noted elsewhere, the Laboratory's highexplosive diagnostic work is conducted at Site 300. Because Site 300 is so remote, these experiments can be performed with minimal off-site impact from annoying noises or damaging overpressures. On the basis of meteorological measurements made twice each day, a limit is set on the weight of high explosives that can be detonated without impact in populated areas. To monitor these limits, four microbarograph sensors are maintained in or near the city of Tracy. The probability of overpressure is greatest in the Tracy area because of the direction of the prevailing winds. The Laboratory received no complaints regarding possible overpressures associated with Site 300 operations during $i 979$.

\section{Pesticide Monitoring}

Beginning in 1975, ine Laboratory's environmental surveillance program was expanded to inclive pesticide monitoring. The pesticides used at LLL include herbicides, fungicides, and insecticides. The must probable way pesticides used at LLL could be transported to the off-site environment is by entrainment in surface runoff water. Most of this

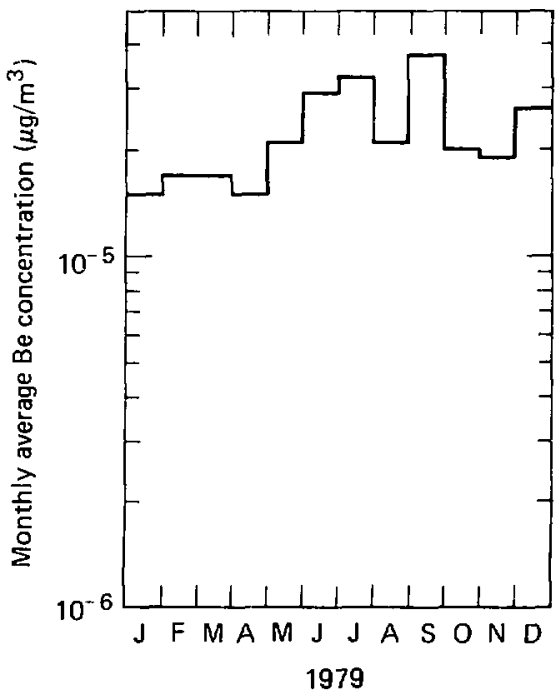

FIG. 15. Beryllium concentration in Site 300 eir filters during 1979. 
surface drainage leaves the Laboratory via a ditch at the northwest corner of the property.

Samples from the ditch were collected following the first fall storm in October 1979. These samples were exiracted with organic solvents. and the extracts were analyzed by gas-liquid chromatography (GLC) using a variety of detectors. Data obtained frem these analyses were compared with the pesticides listed in Title 22 of the California Administrative Code. ${ }^{9}$ No materials were detected in the sar.ples at concentrations exceeding the Stateadopted standards for these organic chemicals.

\section{ENVIRONMENTAL IMPACT OF LLL OPERATIONS}

\section{Radioactive Airborne Emuents}

In 1979 (see Table 32). radioaclive airborne effluents consisted of an estimated $383 \mathrm{Ci}$ of ${ }^{41} \mathrm{Ar}$ from Bldg. 281 (reactor), a total of $4517 \mathrm{Ci}$ of tritium from Bldg. 212 (14-MeV neutron generator) and Bldg. 331 (tritium facility), and $829 \mathrm{Ci}$ of ${ }^{15} \mathrm{O}_{2}{ }^{13} \mathrm{~N}_{2}$ from Bldg. 194 (electron-positron linear accelerator). All radionuclides, with the exception of tritilim, are short-lived. Comparative relesses of radioactive effluents at Livermore during the ficeyear period 1975 through 1979 , together with five year averages are shown in Table 33. The decrease in ${ }^{41} \mathrm{Ar}$ released in 1979 compared with that in 1976 is a result of the termination of LLL's participation in the National Uranium Resource Evaluation (NURE) program, and reduced use of the reactor, which is now scheduled for decommissioning in 1980. The linear accelerator (Building 194) was shut down for about 3 months in 1979. explaining the reduction in ${ }^{13} \mathrm{~N}_{2-}{ }^{15} \mathrm{O}_{2}$ from that of 1978 .

Table 32 also contains estimated radiation doses to the public from these radioactive airborne effuents. Three dose reference points were used: 1) "fence-post" dose at that location on the site boundary where naximum exposure rates exist, 2) the dose to the nearest resident, and 3) the man-rem dose with in a radius of $80 \mathrm{~km}$. The results indicate that the maximum estimated dose to the nearest resident was less than I mrem.

Dose calculations were made using a continuous point source computer code based on the Gaussian plume model. ${ }^{16}$ This code provides ratios of concentration to release rate $(\chi / Q)$ through 16 , $22.5^{\circ}$ compass sectors and distances from 0.1 to 100 $\mathrm{km}$ from potential release points. The average annual $x / Q$ values hav been calculated using local meteorological data from an instrumented tower. This tower, located near the Laboratory's north site boundary, is equippef with sensors mounted at 10 and 40-m levels that measure wind direction. wind speed, and temperature. From records of these data. wind speed, wind direction, and atmospheric stability estimates were tabulated at $1 / 4-h$ intervais over the calendar year. Variance in the horizontal wind direction was used to estimate Pssquill. Gifford stability categories based on the method described by Slade. ${ }^{17}$ Lateral and vertical standard deviations, $\sigma_{z}$ and $\sigma_{f}$ are entered in the computer code as functions of these stability categories and the respective distances. The release rate $Q$ (in (i isec) war calculated from annual effluent data for each of the principal radionuclides released to the a'mosphere, and the concentrations at the site boundary and the nearest resident were calculated from appropriate $x: Q$ values. (Nearest resident means nearest to the radioactivity release point. not nearest to the site boundary.) Dose estimates were based on the dose conversion factor in the U.S. NRC Regulatory Guide $1.109 .{ }^{1 / 3}$ In several cases. the estimated doses are somewhat higher than those teported in 1978. even though the radivactivity released was less. The reasun for this apparent anomaly is that the computer code used in the present calculations adjusts for topography differences. whereas the code used in 1978 calculations did not.

Table 32 shows a combined population dose of man-rem from ${ }^{41} \mathrm{Ar}$, Iritium, and activation products in Laboratory airborne effluents. This dose is based on a population of $4.8 \times 10^{6}$ within $80 \mathrm{~km}$ of the Laboratory. Using $100 \mathrm{mrem} / y$ as a typical average radiation dose from natural sources, the comparable natural radiation dose the same group receives is 3.5 man-rem. By coniparison, the man-rem from Laboratory operations is negligible.

\section{Radioactive Liquid Effluents}

Low-le.el radioactive liquid wastes are, within applicable health and safety standards, discharged into Livermore's sanitary sewer system. During 1979, the principal radionuclides released into the sewer system were $9.8 \times 10^{-4} \mathrm{Ci}$ of ${ }^{239} \mathrm{Pu}$ and $7 \mathrm{Ci}$ of HTO. Table 13 shows that the average annual concentration of these radionuclides represents $3.0 \times$ $10^{-3} \%$ and $2.0 \times 10^{-2} \%$ of the relevant standard. respectively. In addition, the average annual gross 
beta aclivity of the LLL sewage effluent during 1979 was $3.4 \times 10^{-8} \mu \mathrm{Ci}: \mathrm{ml}$. It is assumed that this activity is caused by beta-gamma emittels, which are released into the sewer systenı in accordance with DOE MC 0524. Analyses of samples collected at the point of discharge show the presence of ${ }^{134} \mathrm{Cs}$, ${ }^{137} \mathrm{Cs},{ }^{65} \mathrm{Zn},{ }^{56} \mathrm{Mn},{ }^{60} \mathrm{Co},{ }^{95} \mathrm{Zr},{ }^{95} \mathrm{Nb},{ }^{125} \mathrm{Sb}$, and ${ }^{110} \mathrm{Ag}$. However, even if one or more of these radionuclides were the sole source of the beta activity. none (as shown in Table 34 l would account for over $0.01 \%$ of the $C G$ value listed in DOE MC 0524.

\section{Quality Assurance}

During 1979, the Laboratory participated in the Environmental Protection Agency's interlaboratory Cross Check program and DOE's Sample Analysis Intercomparison program conducted for
DOE by the Environmental Measurements Laboralory (EML). The Laboratory also participated in the 4th International Intercomparison of Environmental Dosineters and continued its quarterly intercomparison of thermoluminescence dosimetry measurements with EML.

A statistical summary is pubiished annually by EML comparing the analytical performance "parlicipating DOE contractors with measurements made by EML. ${ }^{1 /}$ Table 35 shows the comparison of analyses from $\mathrm{LLL}$ with EML for: ${ }^{137} \mathrm{Cs}$ in air, plutonium in air, soil. and water: and tritium in water. The anilytical results are indicated by the ratio of LLL data to that of EML and the ratio of LLL data to the respective meat of all analyses reported.

A description of the sampling and analytical procedures used at LLL has been included as $A_{\Gamma^{-}}$ pendix $D$ in this report. 


\section{REFERENCES}

I. C. L. Lindeken, R. L. Morgan, and K. F. Petrock, "Collection Efficiency of Whatman 41 Filter Paper for Submicron Aerosols," Health Phys. 9, 305 (1963).

2. D. C. Camp, C. Gatrousis, and L. A. Maynard, "Low Background Ge(Li) Detector Systems for Radioenvironmental Studies," Nucl. Instr. Methods 177 (1974).

3. W. J. Silver, C. L. Lindeken, K. N. Wong, A. Conover, and J. H. White, Environmental Moniloring at the Lawrence Livermore Laboratory, 1978 Annual Report, Lawrence Livermore Laboratory, Livermore. Calif., UCRL-50027-78 (1979).

4. "Radiochemcial Determination of Plutonium in Soil by Leaching," HASL Procedure Manual, Procedure E.PU-06, Energy Research and Development Administration, Rept. HASL-300 (1972).

5. W. J. Silver, C. L. Lindeken. J. W. Meadows. W. H. Hutchin, and D. R. Mclntyre. Environmental Levels of Radioactivity in the Vicinity of the Lawrence Livermore Laboratory'. 1973 Annual Report Lawrence Livermore Laboratory, Livermore, Calif., UCRL-51574 (1974).

6. P. H. Gudiksen, C. L. Lindeken, J. W. Meadows, and K. O. Hamby, Envirommenal Levels of Radioactivity in the Vicinity of the $L L L, 1972$ Annual Report, Lawrence Livermore Laboratory, Livermore, Calif., UCRL-51333 (1973).

7. W. J. Tipton, An Aerial Radiological Survey of the Lawrence Livermore Laboratort, EG\&G, Las Vegas, Nevida, Rept. EGG-1183-1693, August 1975.

8. National Interim Primary Drinking Water Regularions, Environmental Protection Agency, EPA-570/976-003 (June 24, 1977).

9. Califormia Domestic Water Quality and Monitoring Regulations. California Administrative Code Title 22. State of California. 1977.

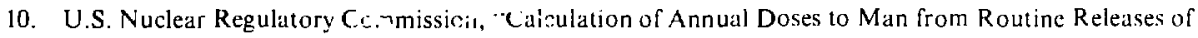
Reactor Effluent for the Purp $\mathrm{se}$ of Evaluating Compliance with 10CFR Part 50, Appendix 1," Regulatory Guide i.l09 (October 1977).

11. W. J. Silver, C. L. Lindeken, K. M. Wong, E. H. Willes, and J. H. White, Environm,tenal Monioning at the Lawrence Livermore Laboratory, 1977 Annual Report, Lawrenci Livermore Laboratory, Livermore. Calif,, UCRL-50027-77 (1978).

12. C. L. Lindeken, J. H. White, A. J. Toy, and C. W. Sundbeck, Ambienl Envirommental Radiation Monitaring at the Lawrence Livermore Laboratory, Lawrence Livermore Laboratory, Livermore, Calif., UCRL77106 (1975).

13. C. L. Lindeken, P. H. Gudiksen, J. W. Meddows, K. O. Hamby, and L. R. Anspiugh, Enironmental Levels of Radioactivity in Litermare Valley Soils, Lawrence Livermore Laboratory. Livermore, Calif.. UCRL-74414 (1975).

14. W. M. Lowder and H. L. Beck, "Cosmic Ray Ionization in the Lower Atmosphere," J. Geo. Phis. Rev: 714611 (1966).

15. J. C. Fisher, Jr., "Calibration of Anderson-Braun Remmeters with 1 rack Etch Detectors" Hazards Control Progress Report No. 52, Lawrence Livermore Laboratory, Livermore, Calif., UCRL 50007-76-1 37 (1976).

16. K. R. Peterson, T. W. Crawforc, and L. A. Lawson, CPS: A Continuous Point Source Compuler Code for Plume Dispersion and Deposition Calculations, Lawrence Livermore Laboratory, Livermore, Calif.. Rept. UCR L-52049 (1976).

17. Meteorology and Atomic Energy, D. H. Slade. Ed,, U.S. Atomic Energy Commission (1968).

18. G. A. Welford. I. M. Fisenne and C. Sanderson. Summary Report of the Department of Energy. Division of Operational and Environmental Safety-Quality Assurance Programs 9 through 12. Environmental Measurements Laboratory. New York. N!: Report EMI. 369 (February I. 1980). 


\section{APPENDIX A. TABLES}

Error values that accompany individual measurements of radioactivity in the following tables are the result of counting statistics. Error values for groups of data like annual averages are salculated standard deviations of the mean (average). A $2 \sigma$ error designaltes those errors from counting. statiscics. and the minimum delection limit is assumed reached when the $2 \sigma$ error is $\pm 100 \%$. Standard deviations of the mean are reported at the $95 \%$ confidence level.

Missing data values are indicated by NS (no sample collected) or by NA (not analyzed). Samples not analyzed were lost after collection, during prosessing, or before analysis. The mis sing values for TLD datta are indicated by "lost" hecause the dosimeters were missing from the sumpling iocattoris at the tim: of collection. 
TABLE 1. Gross alpha activity on air filters at the LLL perimeter and in the Livermore Valley during 1979.

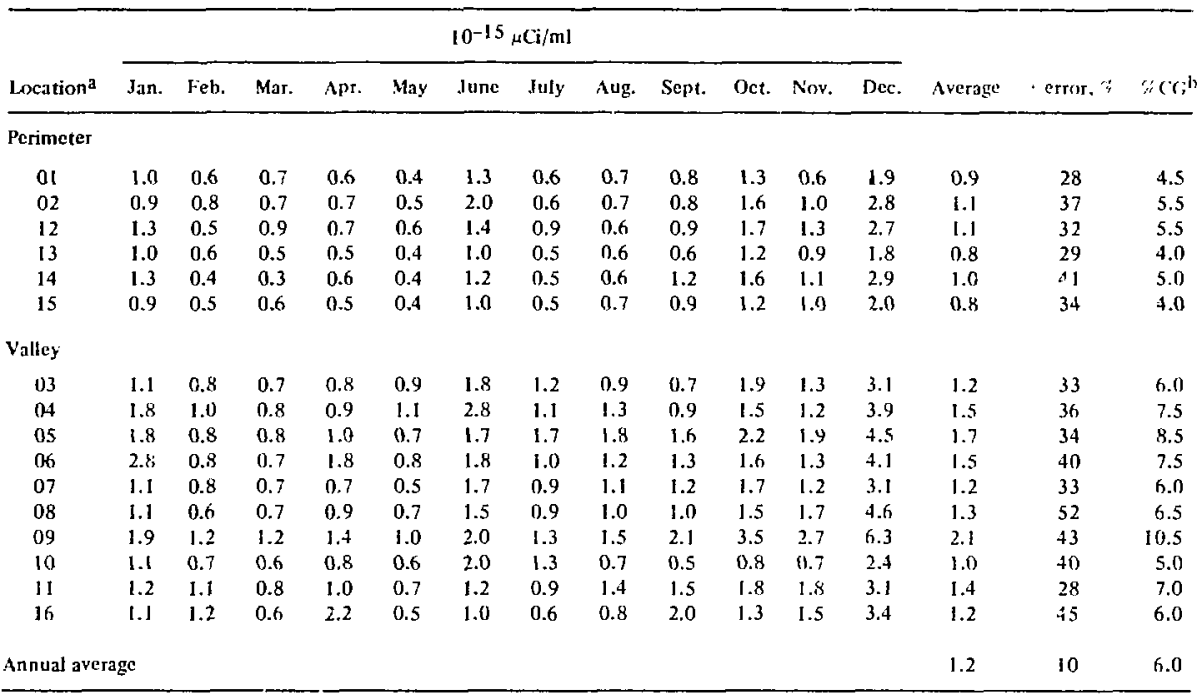

Jee Figs. 3 and 4 ror sampling locations.

bConcentration guide $(\mathrm{CG})=2.0 \mathrm{~F}-14 \mu \mathrm{Ci} / \mathrm{ml}$ for gross alpha activity in air.

(All concentration gujde values are from DOE .MC 0524. Srandards for Radiarion Protecrion. unless ochurwise stated.

TABLE 2. Gross beta activity on air filters collected at the LLL perimeter and in the Livermore Valley during 1979.

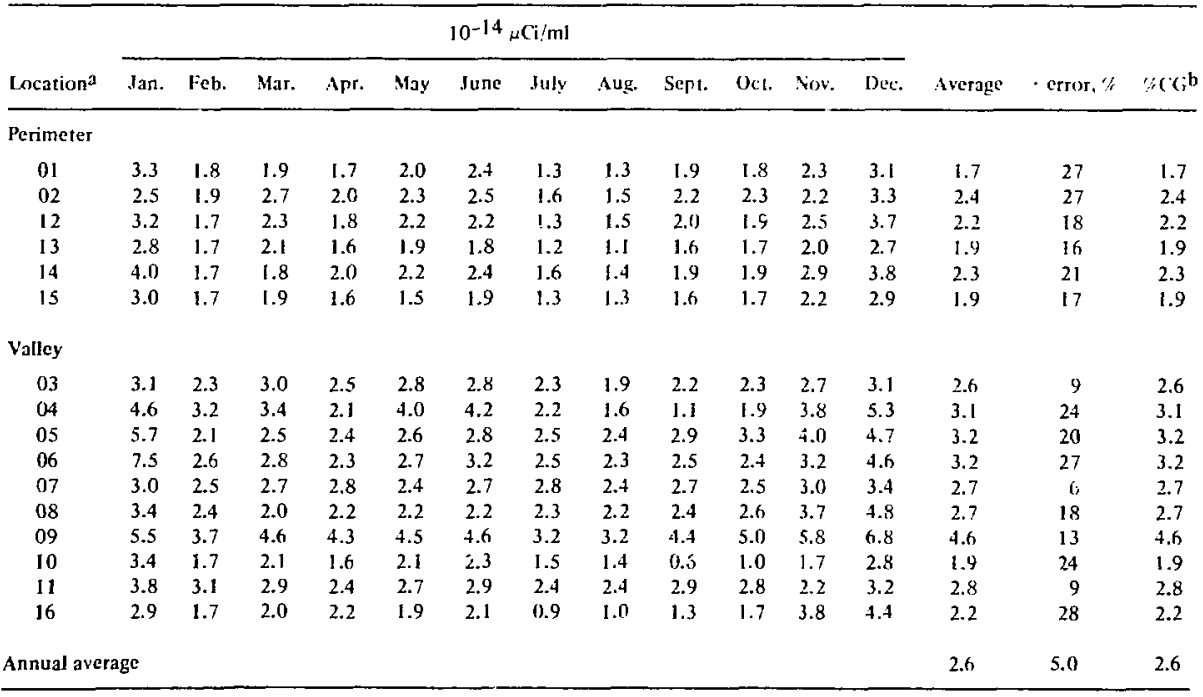

asec Figs. 3 and 4 for sampling locations.

$b_{C G}=1.0$ E-12 for gross beta activity in air. 
TABLE 3. Gross alpha activity on air filters at Site 300 during 1979.

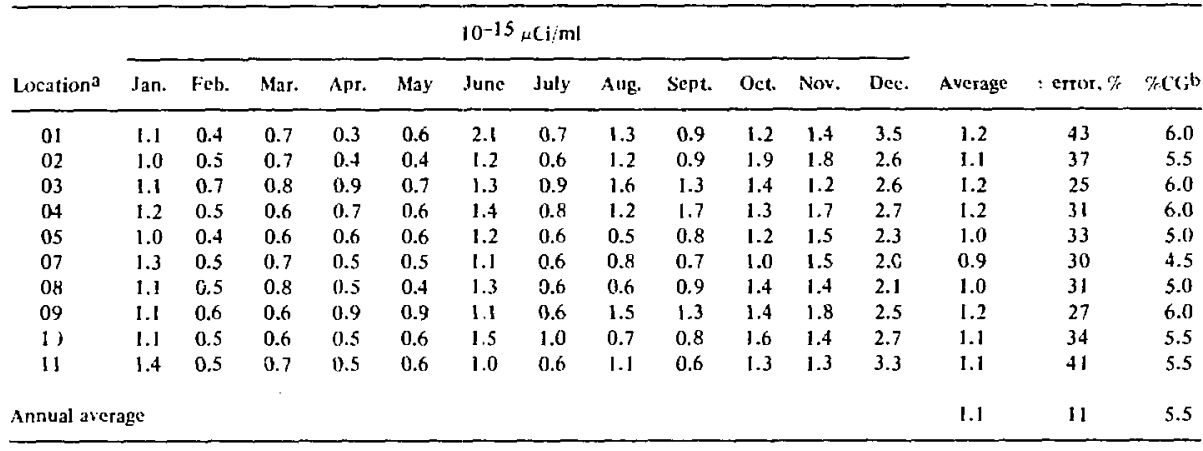

asee Fig. 5 for sampling locations.

$b_{C C}=2.0 \mathrm{E}-14 \mu \mathrm{Ci} / \mathrm{mL}$ for gross alp̧ha activity in air.

TABLE 4. Gross beti activity on air filters at Site 300 during 1979.

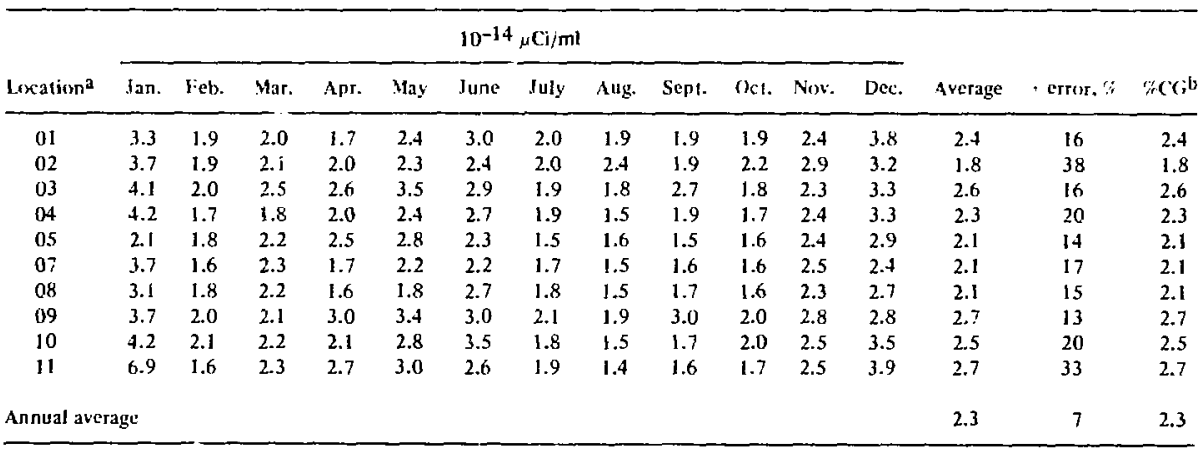

aSee Fig. 5 for sampirg locations.

${ }^{b} \mathrm{C} ;=1.0 \mathrm{E}-1.2 \mu \mathrm{Ci} / \mathrm{ml}$ for gioss beta activity in ais. 
TABLE 5. Results of gamma-riy spectral measurements of LLL perimeter air filters during 1979

\begin{tabular}{|c|c|c|c|c|c|c|}
\hline \multirow[b]{2}{*}{ Month } & \multirow{2}{*}{$\frac{10^{-13} \mu \mathrm{Ci} \times \mathrm{ml} \cdot 2 \sigma^{\prime \prime}}{{ }^{7} \mathrm{Bc}}$} & \multicolumn{5}{|c|}{$10^{-16} \mu\left(\mathrm{i} \mathrm{ml} \cdot 2 \sigma^{\prime}\right.$} \\
\hline & & $40_{K}$ & $106_{\mathrm{Ru}}$ & $125 \mathrm{St}$ & $137 \mathrm{Cs}$ & $144 c i$ \\
\hline Jan. & $1.0 \cdot 2$ & $1.4 \cdot 100$ & $20 \cdot 5$ & $4.1) \cdot 1.5$ & $6.9 \cdot 6$ & $28 \cdot 10$ \\
\hline Feb. & $0.8 \cdot 2$ & $\cdot 1.6 \cdot 100$ & $20 \cdot 16$ & $4.1-14$ & $6.7 \cdot 6$ & $27-8$ \\
\hline Mar. & $0.8 \cdot 2$ & $8.5 \cdot 19$ & $24 \cdot 7$ & $4.3 \cdot 11$ & $8.6 \cdot 4$ & $30-6$ \\
\hline Apr. & $1.0 \cdot 2$ & $4.0 \cdot 48$ & $30 \cdot 5$ & $5.4 \quad 17$ & $12.4 \cdot 4$ & $37 \cdot 4$ \\
\hline Mas & $0.9 \cdot 2$ & $3.0 \cdot 56$ & $31 \cdot 5$ & $6.5 \cdot 9$ & $11.2 \cdot 4$ & $34 \cdot 6$ \\
\hline Јиле & $1.1 \cdot 2$ & $7.0 \cdot 34$ & $32 \cdot 10$ & $6.9 \cdot 9$ & $15.1 \cdot 5$ & $41 \cdot 5$ \\
\hline Iuly & $0.8 \cdot 2$ & $4.0 \cdot 38$ & $14 \cdot 13$ & $2.9 \cdot 13$ & $6.2 \cdot 5$ & $16 \cdot 7$ \\
\hline Aug. & $0.8 \cdot 2$ & $6.0 \cdot 44$ & $11 \cdot 14$ & $2.6 \cdot 20$ & $6.1 \cdot 7$ & $13 \cdot 13$ \\
\hline Sept. & $1.1 \cdot 2$ & $5.0 \cdot 44$ & $9 \cdot 15$ & $2.3 \cdot 23$ & $+.8 \cdot 7$ & $10 \cdot 11$ \\
\hline Oct. & $1.0 \cdot 2$ & $10.0 \cdot 18$ & $8 \cdot 16$ & $1.4 \cdot 26$ & 3.37 & $h \cdot 16$ \\
\hline trox. & $0.7 \cdot 2$ & $\cdot 1.7 \cdot 100$ & $+\cdot 27$ & $0.7 \cdot 53$ & $1.7 \cdot 23$ & $3 \cdot 43$ \\
\hline Det: & $1.1 \cdot 2$ & $1.8 \cdot 100$ & $5 \cdot 31$ & $1.3 \cdot 3 k$ & $3.3 \cdot 16$ & $5 \cdot 25$ \\
\hline Annual urerage & $0.9 F-13$ & $4.5 \mathrm{k}-1 \mathrm{~h}$ & $17 t-16$ & $3.61-16$ & $7.21-16$ & $215-16$ \\
\hline - estur." & 8 & 37 & 34 & 33 & 32 & 37 \\
\hline$c($, & $+.01-08$ & $4.01-09$ & $2.01-10$ & $9.01-10$ & $5.10 \mathrm{f}-10$ & $2.0+-10$ \\
\hline$\because C d$, & $2.3 F-0.4$ & $1.11 \cdot-115$ & $8.51-(1) 4$ & $4.01 \cdot-03$ & $1.41-0.4$ & $1.1+-0) 3$ \\
\hline
\end{tabular}

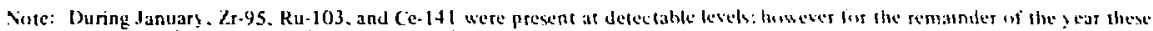
activity concentrations were less than the limits of sensitivity.

TABLE 6. Results of gamma-ray spectral measurements of Site 300 air filters during 1979

\begin{tabular}{|c|c|c|c|c|c|c|}
\hline \multirow[b]{2}{*}{ Ifonth } & \multirow{2}{*}{$\frac{10^{-13}+\left(\mathrm{iml} \cdot 2 \%^{\circ}\right.}{{ }^{7} \mathrm{Bu}}$} & \multicolumn{5}{|c|}{$100^{-16}+\left(\mathrm{i}\right.$ nll $\cdot 20^{*}$} \\
\hline & & $+10 \mathrm{~K}$ & I $(\mathbf{K} \mathrm{Ku}$ & $125 \mathrm{sh}$ & $137 \mathrm{Cs}$ & $144 c$ \\
\hline Jan. & $1.1 \cdot 2$ & $1.0 \cdot 100$ & $28 \cdot 9$ & $4.4 \cdot 11$ & $x \cdot 5$ & $35 \cdot 9$ \\
\hline Feb. & $0.9 \cdot 2$ & $0.9 \cdot 100$ & $21 \cdot h$ & $4.1 \cdot 10$ & $x \cdot 4$ & $29 \cdot 6$ \\
\hline Mar. & $1.0 \cdot 2$ & $4.9 \cdot 24$ & $28-14$ & $5.1-4$ & $11+$ & $37 \cdot 4$ \\
\hline Apr. & $1.0 \cdot 2$ & I.6. 55 & $35 \cdot 3$ & $7.1 \cdot 5$ & $1.3 \cdot 3$ & 423 \\
\hline May & $1.2-2$ & $2.1 \cdot 45$ & $36 \cdot 3$ & $7.3 \cdot 5$ & $13 \cdot 3$ & 413 \\
\hline June & $1.4 \cdot 2$ & $6.0 \cdot 33$ & $43 \cdot h$ & $9.6 \cdot 7$ & $20 \cdot 3$ & $56 \cdot 4$ \\
\hline fuly & $1.2 \cdot 2$ & $3.0 \cdot 53$ & $19 \cdot 10$ & $4.1 \cdot 10$ & $9 \cdot 4$ & $23 \cdot 6$ \\
\hline Aug. & $1.0 \cdot 2$ & $1.3 \cdot 70$ & $14 \cdot 8$ & $3.1 \cdot 18$ & $7 \cdot 5$ & $16 \cdot 11$ \\
\hline Sept. & $1.2 \cdot 2$ & $4.0 \cdot 40$ & $9 \cdot 30$ & $2.3 \cdot 16$ & $4 \cdot 6$ & $10 \cdot 11$ \\
\hline Oct. & $1.0 \cdot 2$ & $5.0 \cdot 20$ & $7 \cdot 11$ & $1.4 \cdot 14$ & $3 \cdot 6$ & $6 \cdot 13$ \\
\hline Sov. & $0.9 \cdot 2$ & $1.0 \cdot 100$ & $4 \cdot 26$ & $0.9 \cdot 29$ & $j \cdot k$ & $5 \quad 20$ \\
\hline Dec. & $0.9 \cdot 2$ & $0.9 \cdot 100$ & $5 \cdot 17$ & $1.0 \cdot 24$ & $3 \cdot 8$ & $5 \cdot 18$ \\
\hline Annual average & $1.1+-13$ & $2.6 v-16$ & $21+-16$ & $4.2+-16$ & $91-16$ & $25 \mathrm{~F}-16$ \\
\hline - error." & 9 & 41 & 37 & 38 & 35 & 39 \\
\hline $\mathrm{CO}$ & $4.0 \mathrm{r}-0.8$ & $4.01-0.9$ & $2.0 \mathrm{t}-10$ & $9.01-10$ & $5.01-10$ & $2.01-16$ \\
\hline$\% C G$ & $2.8 \mathrm{~F}-0.03$ & $6.5 F--06$ & $1 . i t-0) 3$ & $4.7+-05$ & $1.81-1) 4$ & $1.3 \mathrm{~J}-0.03$ \\
\hline
\end{tabular}

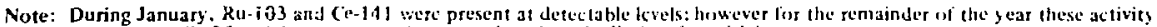
concentrations and $Z_{r} .95$ activity concentrations were less than the linits of sensitivity. 
TABLE 7. ${ }^{239}$ Pu concentrations on air filters in the Livermore Valley during 1979.

$10^{-17} \mu \mathrm{Ci} / \mathrm{ml}$

\begin{tabular}{|c|c|c|c|c|c|c|c|c|c|c|c|c|c|c|c|}
\hline Location ${ }^{3}$ & Jan. & Feb. & Mar. & Apr. & May & June & July & Aug. & Sept. & Oct. & Nov. & Des. & Average & + error, $/ 4$ & $7 \mathrm{cc}$ \\
\hline (1)4 & 1.5 & 1.3 & 1.3 & 1.4 & 2.4 & 4.0 & 1.2 & 1.1 & 0.8 & 0.6 & 0.4 & 0.3 & 1.4 & 43 & $2.3 \mathrm{E}-02$ \\
\hline 10 & 1.5 & 1.2 & I.I & 1.9 & I.6 & 2.7 & 1.3 & 0.7 & 0.4 & 0.3 & 0.2 & 0.4 & 1.1 & 39 & $1.9 \mathrm{E}-02$ \\
\hline 16 & 1.4 & 0.9 & 1.2 & 1.5 & 1.8 & 1.9 & 0.7 & 1.4 & 0.9 & 0.4 & 0.4 & I. I & 1.1 & 25 & $1.9 \mathrm{E}-02$ \\
\hline
\end{tabular}

aSee fig. 4 for sampling locations.

$h_{(\mathrm{C}}=6.0 \mathrm{~F}-14 \mathrm{~m}\left(\mathrm{i} \mathrm{ml} f(0) 23{ }^{9} \mathrm{Pu}(\right.$ soluble $)$ activity in air.

TABLE \&. Plutonium, cesium, and uranium concentrations of LLL perimeter air filters during 1979.

\begin{tabular}{|c|c|c|c|c|c|c|c|c|}
\hline & & $\begin{array}{c}\mid 0-17 \mu \mathrm{Ci} / \mathrm{ml} \\
2 \% \%\end{array}$ & {$\left[0^{-2} \cdot 2 o^{\prime \prime}\right.$} & $\begin{array}{c}10^{-15} \mu \mathrm{Ci} ; \mathrm{ml} \\
\cdot 2 \sigma^{\prime} \%\end{array}$ & $10^{-2} \cdot 2 \sigma^{\prime} t$ & $\begin{array}{c}10^{-7} \mu \mathrm{g} / \mathrm{m}^{3} \\
\cdot 20^{2} /\end{array}$ & $\begin{array}{c}10^{-5} \mu \mathrm{g} / \mathrm{m}^{3} \\
2 \sigma^{6} \%\end{array}$ & $10^{-3} \cdot 20 \%$ \\
\hline Ylonth & Loreationa & 239] & $238 \mathrm{Pu} ;{ }^{239} \mathrm{Pu}$ & $137 \mathrm{Cs}$ & $239 \mathrm{Pu}_{i} 37 \mathrm{Cs}$ & $235 \mathrm{C}$ & $238_{\mathrm{L}}$ & $235 U / 238 U$ \\
\hline \multirow[t]{6}{*}{ חמכו. } & 01 & $0.9 \cdot 12$ & $5.0 \cdot 55$ & $0.8 \cdot 5$ & $1.2 \cdot 13$ & $1.9 \cdot 2$ & $2.8 \cdot 2$ & $6.9 \pm 1$ \\
\hline & 02 & $0.8 \cdot 17$ & $5.0-70$ & $0.7 \cdot 6$ & $1.2 \cdot 18$ & $4.1 \cdot 2$ & $5.9+2$ & $7.1 \pm 1$ \\
\hline & 12 & $1.7 \cdot 10$ & $4.0 \cdot 46$ & $0.6 \cdot 5$ & $2.7=11$ & $3.7: 2$ & $5.5 \cdot 2$ & $6.7 \pm 1$ \\
\hline & 13 & $2.6 \cdot 9$ & $1.4 \cdot 65$ & ก.5 5 & $5.0=10$ & $1.8 \cdot 1$ & $2.6 \cdot 1$ & $7.0+1$ \\
\hline & 14 & $1.1 \cdot 13$ & $3.0 \cdot 65$ & $0.8 \cdot 4$ & $1.4 \cdot 14$ & $1.7 \cdot 2$ & $2.7 \cdot 1$ & $6.4+2$ \\
\hline & 15 & $0.7 \cdot 14$ & $\mathrm{NA}$ & $0.6 \cdot 5$ & $1.1 \cdot 15$ & $1.8 \cdot 1$ & $2.6 \cdot 1$ & $7.0 \div 1$ \\
\hline \multirow[t]{6}{*}{ reb. } & 01 & $0.9 \cdot 12$ & $4.0 \cdot 55$ & $0.7 \cdot 6$ & $1.4 \cdot 13$ & $1.7 \cdot 1$ & $2 \ldots+1$ & $6.8 \div 1$ \\
\hline & 02 & $0.8 \cdot 13$ & $2.0 \cdot 85$ & $0.7 \cdot 6$ & $1.2 \cdot 14$ & $4.0 \cdot 1$ & $5.7 \cdot:$ & $7.0 \div 1$ \\
\hline & 12 & $1.1 \cdot 12$ & $4.0 \cdot 60$ & $0.6 \cdot 5$ & $1.8 \cdot 13$ & $4.0 \cdot 1$ & $6.1 \cdot 1$ & $6.6 \div 1$ \\
\hline & 13 & $0.9 \cdot 12$ & $7.0 \cdot 46$ & $0.6 \cdot 6$ & $1.5 \cdot 13$ & I. $8 \cdot 1$ & $2.6 \cdot 1$ & $6.9 \cdot 1$ \\
\hline & 14 & $0.9 \cdot 14$ & $6.0 \cdot 57$ & $0.7 \cdot 6$ & $1.3 \cdot 15$ & $1.4 \cdot 2$ & $2.2 \cdot 1$ & $6.2 \div 1$ \\
\hline & 15 & $0.7 \cdot 14$ & $3.0 \cdot 90$ & $0.6 \cdot 5$ & $1.2 \cdot 15$ & $1.6 \cdot 1$ & $2.4 \cdot 1$ & $6.7 \cdot 1$ \\
\hline \multirow[t]{6}{*}{ Mar. } & $0 \mathrm{I}$ & $0.8 \cdot 15$ & $5.0 \cdot 65$ & $0.7 \cdot 4$ & $1.1 \cdot 16$ & $1.5 \cdot 2$ & $2.2+1$ & $6.9 \cdot 1$ \\
\hline & 02 & $1.1 \cdot 16$ & $8.0 \cdot 60$ & $0.9 \cdot 4$ & $1.2 \cdot 16$ & $2.8 \cdot 2$ & $4.0 \cdot 2$ & $7.2: 1$ \\
\hline & 12 & $1.1 \cdot 15$ & $3.0 \cdot 85$ & $0.8-4$ & $1.3 \div 16$ & $5.3: 2$ & $7.7 \cdot 2$ & $7.0 \cdot 1$ \\
\hline & 13 & $0.9 \cdot 16$ & $4.0 \cdot 80$ & $0.7 \cdot 4$ & $1.4 \cdot 16$ & $1.5 \cdot 2$ & $2.1 \cdot 2$ & $7.2 \cdot 1$ \\
\hline & 14 & $1.0 \cdot 17$ & $4.0 \cdot 90$ & $0.7 \cdot 4$ & $1.4 \cdot 17$ & $1.3 \cdot 1$ & $1.9 \cdot 1$ & $6.5 \cdot 1$ \\
\hline & 15 & $0.8 \cdot 14$ & $5.0 \cdot 60$ & $0.7 \cdot 4$ & $1.1 \cdot 15$ & $1.9 \cdot 2$ & $2.8+1$ & $7.0-1$ \\
\hline \multirow[t]{6}{*}{ Apr. } & $0 \mathrm{I}$ & $1.8+18$ & $\mathrm{NA}$ & $1.1 \cdot 4$ & $1.6 \cdot 18$ & $2.7: 2$ & $6.0 \cdot 1$ & $4.6+1$ \\
\hline & 02 & $1.3 \cdot 18$ & $5.0 \cdot 80$ & $1.2 \cdot 4$ & $1.1 \cdot 18$ & $2.9 \cdot 2$ & $5.5+2$ & $.3 .3 \pm 1$ \\
\hline & 12 & $1.5 \cdot 17$ & $7.0 \cdot 60$ & $1.1+4$ & $1.3 \cdot 17$ & $5.6 \cdot 2$ & $9.7+2$ & $5.9+1$ \\
\hline & 13 & $1.3 \cdot 19$ & $4.0 \cdot 90$ & $1.0 \cdot 3$ & $1.3=19$ & $2.3 \div 2$ & $4.4,2$ & $5.2 \div 1$ \\
\hline & 14 & $1.8 \cdot 12$ & $4.0 \cdot 50$ & $1.2 \cdot 3$ & $1.5 \cdot 12$ & $2.2+2$ & $4.6+2$ & $4.8 \pm 1$ \\
\hline & I5 & $1.4 \cdot 14$ & $3.0 \cdot 70$ & $1.0+4$ & $1.4 \cdot 15$ & $2.5 \quad 2$ & $4.9+2$ & $5.2 \geq 1$ \\
\hline \multirow[t]{6}{*}{ May } & 01 & $1.5 \cdot 10$ & $5.0 \cdot 44$ & $1.1 \cdot 3$ & $1.4 \cdot 10$ & $3.7: 2$ & $5.1 \div 2$ & $7.3 \cdot 1$ \\
\hline & 02 & $1.4 \cdot 10$ & $2.0 \cdot 70$ & $1.3 \cdot 3$ & $1.1+10$ & $4.0 \cdot 2$ & $5.0 \cdot 1$ & $7.2=1$ \\
\hline & 12 & $1.3 \cdot 10$ & $3.0 \cdot 60$ & $1.2+3$ & $1.1 \cdot 10$ & $6.5+1$ & $9.3 \cdot 1$ & $7.1=1$ \\
\hline & 13 & $1.3 \cdot 10$ & $1.1+90$ & $1.1 \div 3$ & $1.2 \cdot 10$ & $2.5 \div 2$ & $3.6 \cdot 2$ & $7.2 \div 1$ \\
\hline & 14 & $1.9 \cdot 7$ & $6.0 \cdot 26$ & $1.2 \cdot 3$ & $1.6 \cdot 8$ & $2.6 \pm 2$ & $3.7 \cdot 1$ & $7.1 \pm 1$ \\
\hline & 15 & $1.3 \cdot 9$ & $1.1 \cdot 80$ & $1.1 \cdot 3$ & $1.2 \div 9$ & $3.3 \pm 2$ & $4.7: 2$ & $7.2 \pm 1$ \\
\hline \multirow[t]{6}{*}{ June } & (1) & $2.0 \cdot 11$ & $8.0 \cdot 38$ & $1.6 \cdot 4$ & $1.3=12$ & $6.9 \div 1$ & $9.6 \pm 1$ & $7.3 \pm 1$ \\
\hline & 02 & $1.7 \cdot 13$ & $2.0 \cdot 74$ & $1.6 \cdot 4$ & $1.1=14$ & $6.4 \div 1$ & $9.1 \div 1$ & $7.1 \pm 1$ \\
\hline & 12 & $1.9 \cdot 13$ & $3.0 \cdot 72$ & $1.5 \cdot 5$ & $1.3+14$ & $8.8 \pm 2$ & $13.1+1$ & $6.8 \pm 1$ \\
\hline & 13 & $1.6 \cdot 12$ & $3.0 \div 61$ & $1.3 \cdot 4$ & $1.2 \pm 13$ & $4.3 \div 2$ & $6.0 \div 1$ & $7.2 \div 1$ \\
\hline & 14 & $6.0 \cdot 7$ & $9.0 \cdot 18$ & $1.5 \cdot 3$ & $4.0 \div 8$ & $5.7 \pm 2$ & $8.0 \pm 1$ & $7.1 \pm 1$ \\
\hline & 15 & $1.6 \cdot 12$ & $3.0 \cdot 18$ & $1.3 \cdot 7$ & $1.2 \cdot 14$ & $5.9 \div 2$ & $8.2 \div I$ & $7.3: 1$ \\
\hline
\end{tabular}


TABLE 8. (Continued.)

\begin{tabular}{|c|c|c|c|c|c|c|c|c|}
\hline & & $\begin{array}{c}10-17 \mu \mathrm{Ci} / \mathrm{ml} \\
+2 \% \%\end{array}$ & $10^{-2} \cdot 2 \sigma^{\prime} t$ & $\begin{array}{c}10^{-15}{ }_{\mu \mathrm{Ci}} / \mathrm{ml} \\
2 \sigma \%\end{array}$ & $10^{-2} \cdot 2 \mathrm{~s} / \%$ & $\begin{array}{c}10-7 \mu \mathrm{g} / \mathrm{m}^{3} \\
\cdot 2 \pi \%\end{array}$ & $\begin{array}{c}10^{-5} \mu \mathrm{g} / \mathrm{m}^{3} \\
\cdot 2 \sigma^{\prime} \%\end{array}$ & $10^{-3} \cdot 2 \pi^{z}$ \\
\hline Mondl & Locationa & $239 \mathrm{Pub}$ & $238 \mathrm{Pu} / 239 \mathrm{Pu}$ & ${ }^{137} \mathrm{Cs}$ & $239 \mathrm{Pu} / 137 \mathrm{Cs}$ & $235 \mathrm{~L}$ & $238 \mathrm{~L}$ & $235 \mathrm{~L} / 238 \mathrm{C}$ \\
\hline July & $\begin{array}{l}01 \\
02 \\
12 \\
13 \\
14 \\
15\end{array}$ & $\begin{array}{l}0.9: 14 \\
0.8=14 \\
0.8 \cdot 11 \\
0.6 \pm 13 \\
4.2 \cdot 5 \\
0.7 \cdot 11\end{array}$ & $\begin{array}{r}8.0 \cdot 45 \\
2.0 \cdot 85 \\
6.0 \cdot 44 \\
4.0 \div 60 \\
11.0 \cdot 13 \\
5.0 \cdot 47\end{array}$ & $\begin{array}{l}0.5 \pm 6 \\
0.6 \cdot 4 \\
0.6 \cdot 4 \\
0.6: 4 \\
0.7: 4 \\
0.6 \cdot 6\end{array}$ & $\begin{array}{l}1.7 \cdot 15 \\
1.3 \cdot 14 \\
1.5 \cdot 12 \\
1.1 \cdot 14 \\
6.4 \cdot 6 \\
1.2=13\end{array}$ & $\begin{array}{l}4.1 \cdot 2 \\
3.8 \cdot 2 \\
6.5=2 \\
3.1 \cdot 2 \\
4.0 \cdot 2 \\
4.5 \cdot 2\end{array}$ & $\begin{array}{l}5.8: 2 \\
5.3 \cdot 1 \\
9.2 \cdot 2 \\
4.4 \cdot 2 \\
5.7 \cdot 2 \\
6.4 \cdot 2\end{array}$ & $\begin{array}{l}7.1 \cdot 1 \\
7.2 \cdot 1 \\
7.1 \cdot 1 \\
7.2=1 \\
7.1=1 \\
7.1=1\end{array}$ \\
\hline Aug. & $\begin{array}{l}01 \\
02 \\
12 \\
13 \\
14 \\
15\end{array}$ & $\begin{array}{l}0.9 \cdot 18 \\
0.8=18 \\
1.4 \cdot 14 \\
0.6 \cdot 21 \\
5.2 \cdot 8 \\
0.5 \cdot 23\end{array}$ & $\begin{aligned} 9.0 \cdot 60 \\
1.0 \cdot 100 \\
5.0 \cdot 59 \\
2.0 \cdot 100 \\
13.0 \cdot 19 \\
1.0 \cdot 100\end{aligned}$ & $\begin{array}{l}0.6 \cdot 4 \\
0.7 \cdot 4 \\
0.6 \cdot 4 \\
0.5 \cdot 8 \\
0.6 \cdot 4 \\
0.6 \cdot 5\end{array}$ & $\begin{array}{l}1.5 \cdot 18 \\
1.1 \cdot 18 \\
2.3 \cdot 15 \\
1.2 \cdot 22 \\
9.0 \cdot 9 \\
0.9 \cdot 24\end{array}$ & $\begin{array}{l}7.9 \cdot 2 \\
4.0 \cdot 2 \\
8.2 \cdot 2 \\
2.7 \cdot 2 \\
6.2 \cdot 2 \\
4.8 \cdot 2\end{array}$ & $\begin{array}{r}11.1 \cdot 2 \\
5.6 \cdot 2 \\
11.7 \cdot 1 \\
3.8 \cdot 2 \\
8.7 \cdot 2 \\
6.8 \cdot 2\end{array}$ & $\begin{array}{l}7.2 \cdot 1 \\
7.2 \cdot 1 \\
7.1 \cdot 1 \\
7.3=1 \\
7.2 \cdot 1 \\
7.1 \cdot 1\end{array}$ \\
\hline Sept. & $\begin{array}{l}01 \\
02 \\
12 \\
13 \\
14 \\
15\end{array}$ & $\begin{array}{l}0.9 \cdot 16 \\
0.6 \cdot 25 \\
2.8 \cdot 10 \\
0.5 \cdot 22 \\
3.6 \cdot 7 \\
0.6 \cdot 18\end{array}$ & $\begin{array}{c}8.0 \cdot 55 \\
4.0 \cdot 100 \\
9.0 \cdot 31 \\
7.0 \cdot 82 \\
11.0 \cdot 19 \\
2.0 \cdot 100\end{array}$ & $\begin{array}{l}0.6 \cdot 8 \\
0.7 \cdot 14 \\
0.6 \cdot 8 \\
0.5 \cdot 6 \\
0.5=7 \\
0.5=7\end{array}$ & $\begin{array}{l}1.6 \cdot 18 \\
0.8 \cdot 29 \\
4.7 \cdot 13 \\
1.0 \cdot 23 \\
6.9 \cdot 10 \\
1.3 \cdot 19\end{array}$ & $\begin{array}{l}6.5 \cdot 3 \\
5.1 \cdot 2 \\
9.7 \cdot 2 \\
3.9 \cdot 2 \\
4.8 \cdot 2 \\
4.4 \cdot 2\end{array}$ & $\begin{array}{r}9.3 \cdot 3 \\
7.1 \cdot 2 \\
13.7 \cdot 2 \\
5.4 \cdot 2 \\
6.7 \cdot 1 \\
6.2 \cdot 2\end{array}$ & $\begin{array}{l}7.2 \cdot 2 \\
7.3 \cdot 1 \\
7.2-1 \\
7.2 \cdot 1 \\
7.2 \cdot 1 \\
7.2 \quad 1\end{array}$ \\
\hline Oct. & $\begin{array}{l}01 \\
02 \\
12 \\
13 \\
14 \\
15\end{array}$ & $\begin{array}{l}1.2 \cdot 12 \\
0.5 \cdot 18 \\
2.6 \cdot 8 \\
0.5 \cdot 18 \\
0.6 \cdot 14 \\
2.1 \cdot 9\end{array}$ & $\begin{array}{r}7.0 \cdot 44 \\
4.0 \cdot 91 \\
12.0 \cdot 21 \\
4.0 \cdot 93 \\
6.0 \cdot 56 \\
11.0 \cdot 24\end{array}$ & $\begin{array}{l}0.4 \cdot 6 \\
0.5 \cdot 7 \\
0.4 \cdot 7 \\
0.4 \cdot 6 \\
0.4 \cdot 6 \\
0.4 \cdot 5\end{array}$ & $\begin{array}{l}3.1 \cdot 13 \\
1.2 \cdot 19 \\
6.5 \cdot 11 \\
1.1 \cdot 19 \\
1.4 \cdot 15 \\
5.1 \cdot 10\end{array}$ & $\begin{array}{l}4.3 \cdot 2 \\
5.2 \cdot 2 \\
8.9 \cdot 2 \\
3.7 \cdot 2 \\
3.8 \cdot 2 \\
3.5 \cdot 2\end{array}$ & $\begin{array}{r}6.1 \cdot 2 \\
7.4 \cdot 2 \\
12.6 \cdot 2 \\
5.1 \cdot 2 \\
5.4 \cdot 2 \\
4.9 \cdot 2\end{array}$ & $\begin{array}{l}7.1-1 \\
7.2 \cdot 1 \\
7.1-1 \\
7.3-1 \\
7.1-1 \\
7.2 \cdot 1\end{array}$ \\
\hline Sov. & $\begin{array}{l}01 \\
02 \\
12 \\
13 \\
14 \\
15\end{array}$ & $\begin{array}{l}0.6 \cdot 18 \\
0.6 \cdot 23 \\
2.7 \cdot 11 \\
2.4 \cdot 30 \\
0.7 \cdot 16 \\
0.5 \cdot 19\end{array}$ & $\begin{array}{c}4.0 \cdot 86 \\
3.0 \cdot 100 \\
7.0 \cdot 35 \\
N A \\
12.0 \cdot 47 \\
6.0 \cdot 78\end{array}$ & $\begin{array}{l}0.3-14 \\
0.3 \cdot 10 \\
0.3 \cdot 12 \\
0.2 \cdot 8 \\
0.4 \cdot 9 \\
0.2 \cdot 11\end{array}$ & $\begin{array}{r}2.2 \cdot 23 \\
2.4 \cdot 25 \\
10.0 \cdot 16 \\
10.0 \cdot 31 \\
1.6 \cdot 18 \\
2.0 \cdot 22\end{array}$ & $\begin{array}{l}2.2 \cdot 2 \\
3.2 \cdot 4 \\
5.4 \cdot 2 \\
2.1 \cdot 2 \\
2.3 \cdot 2 \\
2.4 \cdot 2\end{array}$ & $\begin{array}{l}3.5 \cdot 2 \\
4.8 \cdot 3 \\
7.9 \cdot 2 \\
3.0 \cdot 2 \\
3.5 \cdot 2 \\
3.6 \cdot 2\end{array}$ & $\begin{array}{l}6.5 \cdot 1 \\
6.7 \cdot 3 \\
6.9 \cdot 1 \\
6.9 \cdot 1 \\
6.7 \cdot 1 \\
6.9 \cdot 1\end{array}$ \\
\hline Des. & $\begin{array}{l}01 \\
02 \\
12 \\
13 \\
14 \\
15\end{array}$ & $\begin{array}{l}0.8 \cdot 16 \\
0.5: 2 i \\
1.8 \cdot 11 \\
0.5 \cdot 19 \\
0.5: 21 \\
0.5 \cdot 18\end{array}$ & $\begin{array}{r}5.0 \cdot 74 \\
7.0 \cdot 79 \\
11.0 \cdot 32 \\
12.0 \cdot 56 \\
22.0 \cdot 47 \\
2.0 \cdot 100\end{array}$ & $\begin{array}{l}0.4 \cdot 7 \\
0.4 \cdot 6 \\
0.5 \cdot 5 \\
0.4 \cdot 6 \\
0.4 \cdot 2 \\
0.3 \cdot 6\end{array}$ & $\begin{array}{l}1.9 \cdot 17 \\
1.3 \cdot 22 \\
4.0 \cdot 12 \\
1.2 \cdot 20 \\
1.6 \cdot 21 \\
1.5 \cdot 19\end{array}$ & $\begin{array}{l}2.6 \cdot 2 \\
3.0 \cdot 2 \\
6.9 \cdot 2 \\
2.6 \cdot 2 \\
3.5 \cdot 2 \\
3.0 \cdot 2\end{array}$ & $\begin{array}{r}3.9 \cdot 2 \\
4.4 \cdot 2 \\
10.3 \cdot 2 \\
4.2 \cdot 2 \\
3.7 \cdot 2 \\
4.3 \cdot 1\end{array}$ & $\begin{array}{l}6.9 \cdot 1 \\
6.8 \cdot 1 \\
6.8=1 \\
6.2 \cdot 1 \\
6.8 \cdot 1 \\
7.0 \cdot 1\end{array}$ \\
\hline
\end{tabular}

\begin{tabular}{|c|c|c|c|c|c|c|c|c|c|c|c|c|}
\hline \multicolumn{13}{|c|}{ Annual averages } \\
\hline \multirow[b]{2}{*}{ Locationa } & \multicolumn{3}{|c|}{$10^{-17} \mu \mathrm{Ci}: \mathrm{ml}$} & \multicolumn{3}{|c|}{$10^{-15} \mu \mathrm{Ci} / \mathrm{ml}$} & \multicolumn{3}{|c|}{$1 \mathrm{~g}^{-7} \mu \mathrm{g} / \mathrm{m}^{3}$} & \multicolumn{3}{|c|}{$10^{-5} \mu \mathrm{g} / \mathrm{m}^{3}$} \\
\hline & $239 \mathrm{Pu}$ & - error. $\%$ & $\pi c i^{c}$ & ${ }^{137} \mathrm{Cs}$ & , error." & 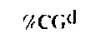 & $235_{L}$ & error, $z$ & $\operatorname{scc} 0^{\mathrm{c}}$ & $238 \mathrm{C}$ & error. 7 & $3 \mathrm{CG}^{\mathrm{r}}$ \\
\hline 01 & 1.1 & 23 & $1.8 E-02$ & 0.7 & 30 & $1.5 \mathrm{~F}-04$ & 3.8 & 33 & $\therefore 0 \mathrm{~F}-05$ & 5.7 & 30 & $3.8 F-04$ \\
\hline 02 & 0.9 & 24 & $1.5 \mathrm{~F}-02$ & 0.8 & 29 & $1.6 \mathrm{~F}-04$ & 4.0 & 15 & $2.1 \mathrm{~F}-05$ & 5.9 & 14 & $3.9 \mathrm{~F}-04$ \\
\hline 12 & 1.7 & 22 & $2.8+-02$ & 0.7 & 29 & $1.5 \mathrm{E}:-04$ & 6.6 & 17 & $3.5 \mathrm{E}-0 \mathrm{~S}$ & 8.7 & 20 & $5.8 \mathrm{E}-04$ \\
\hline 13 & 1.1 & 37 & $1.8 \mathrm{E}-02$ & 0.7 & 29 & $1.3 \mathrm{~F}-04$ & 2.7 & 19 & 1.4 E-0S & 3.9 & I 8 & $2.6 \mathrm{~F}-04$ \\
\hline 14 & 2.3 & 49 & $3.8 \mathrm{E}-02$ & 0.8 & 27 & $1.5 \mathrm{E}-04$ & 3.2 & 30 & $1.7 \mathrm{E}-05$ & 4.8 & 27 & $3.2 \mathrm{E}-04$ \\
\hline 15 & 1.0 & 32 & $1.7 \mathrm{~F}-02$ & 0.7 & 29 & $1.3 F-04$ & 3.3 & 23 & 1.7 F-05 & 4.8 & 22 & $3.2 \mathrm{~F}-04$ \\
\hline
\end{tabular}

aSee Fig. 3 for sampling locations.

bIn all tables, activity listed as $239 \mathrm{Pu}$ includes activity due to the $240 \mathrm{Pu}$ isotope.

${ }^{c} \mathrm{CG}=6.0 \mathrm{E}-14 \mu \mathrm{Ci} / \mathrm{ml}$ for 239 Py (soluble) activity in air.

${ }^{d} \mathrm{CC}=5.0 \mathrm{E}-10 \mu \mathrm{Ci} / \mathrm{ml}$ for $137 \mathrm{Cs}$ (insoluble) activity in ais.

$e_{\mathrm{CC}}=1.9 \mathrm{\mu g} / \mathrm{m}^{3}$ for $235_{\mathrm{L}}$ (insoluble) activity in air.

$\Upsilon_{C G}=15.0 \mathrm{\mu g} / \mathrm{m}^{3}$ for $238 \mathrm{~L}$ (insoluble) activity in air. 
TABLE 9. Plutonium, cesium. and uranium concentrations on air filters at Site 300 during 1979.

\begin{tabular}{|c|c|c|c|c|c|c|c|}
\hline & $\begin{array}{c}10^{-17} \mu \mathrm{Ci}: \mathrm{ml} \\
20 \%\end{array}$ & $10^{-2} \cdot 2 v^{2} \%$ & $\begin{array}{c}10^{-15} \mu \mathrm{Ci} / \mathrm{ml} \\
-2 o \%\end{array}$ & $10^{-2} \cdot 20 \%$ & $\begin{array}{c}10^{-7} \mu \mathrm{g} / \mathrm{m}^{3} \\
-20 \%\end{array}$ & $\begin{array}{c}10^{-5} \mu \mathrm{g} / \mathrm{m}^{3} \\
\cdot 2 a \%\end{array}$ & $10^{-3} \div 2 \sigma^{\prime} r$ \\
\hline Month & ${ }^{23} 9^{\mathrm{Pu}}$ & $238 \mathrm{Pu} / 239 \mathrm{Pu}$ & $137 \mathrm{Cs}$ & $239 \mathrm{Pu} / 37 \mathrm{Cs}$ & $235 \mathrm{U}$ & $238 \mathrm{~L}$ & $235_{\mathrm{L}} \because 238_{\mathrm{C}}$ \\
\hline Jan. & $1.4 \cdot 6$ & $3.0 \cdot 22$ & $0.8 \cdot 2$ & $1.8 \cdot 6$ & $4.2 \cdot 1$ & $14.1 \cdot 2$ & $3.0 \cdot 1$ \\
\hline Feh. & $1.1 \cdot 7$ & $2.6 \cdot 28$ & $0.7 \cdot 1$ & $1.6 \cdot 7$ & $1.9 \cdot 2$ & $4.9=2$ & $3.8-1$ \\
\hline Mar. & $1.2 \cdot 6$ & $1.5: 31$ & $0.8 \cdot 1$ & $1.5: 6$ & $3.4 \cdot i$ & $12.8+1$ & $2.7 \cdot 1$ \\
\hline Apr- & $1.7 \cdot 6$ & $1.8 \cdot 23$ & $1.3=1$ & $1.3 \cdot 6$ & $3.4: 1$ & $9.2 \cdot 1$ & $3.7 \cdot 1$ \\
\hline May & $2.0 \cdot 3$ & $2.5 \cdot 12$ & $1.4 \cdot 2$ & $1.4 \cdot 4$ & $3.4 \cdot 1$ & $5.8 \cdot 1$ & $5.9 \cdot 1$ \\
\hline June & $2.4 \cdot 6$ & $2.7 \cdot 21$ & $1.6 \cdot 1$ & $1.5+6$ & $6.1 \cdot 1$ & $11.8 \cdot 1$ & $5.2 \cdot 1$ \\
\hline July & $1.1 \cdot 5$ & $2.2 \cdot 23$ & $0.8 \cdot 2$ & $1.4 \cdot 5$ & $4.3 \cdot 1$ & $7.1 \cdot 1$ & $0.0 \cdot 1$ \\
\hline lug. & $1.1 \cdot 6$ & $2.3 \cdot 31$ & $0.8 \cdot 2$ & $1.4 \cdot 6$ & $4.1 \cdot 1$ & $6.7+1$ & $6.1 \cdot 1$ \\
\hline Sept. & $0.7 \cdot 7$ & $2.2 \cdot 34$ & $0.5 \cdot 3$ & $1.6 \cdot 8$ & $5.9 \cdot 1$ & $11.2 \cdot 1$ & $5.3-1$ \\
\hline Oct. & $0.6 \cdot 6$ & $2.9 \cdot 25$ & $0.4 \cdot 4$ & $1.8 \cdot 8$ & $5.2: 1$ & $10.1 \cdot 1$ & $5.2 \cdot 1$ \\
\hline Niov. & $0.7 \cdot 7$ & $2.2 \cdot 35$ & $2.5 \cdot 2$ & $2.6 \cdot 7$ & $3.8 \cdot i$ & $10.0 \cdot 1$ & $3.9 \cdot 1$ \\
\hline Dec. & $2.8 \cdot 5$ & $3.2 \cdot 15$ & $2.8 \cdot 3$ & $1.0 \cdot 6$ & $4.4 \cdot 1$ & $12.6 \cdot 1$ & $3.5 \cdot 1$ \\
\hline Annual average & $1.4 \mathrm{r}-17$ & & (1.) $1-15$ & & $4.2 \mathrm{E}-07$ & $9.7 \mathrm{E}-05$ & \\
\hline error." & 28 & & 33 & & 16 & 18 & \\
\hline $\mathrm{Cr}_{i}$ & $6.0 t:-14$ & & $5.0 \mathrm{~F}-10$ & & $1.9 E+00$ & $1.5 \mathrm{E}+01$ & \\
\hline :CC & $2.3 \mathfrak{r}-02$ & & $1.6 \mathrm{~F}-04$ & & $2.2 \mathrm{E}-05$ & $6.5 \mathrm{E}-0.4$ & \\
\hline
\end{tabular}

TABLE 10. Tritiun (HTO) in air at the LLL perimeter and in the Livermore Valley during 1979.

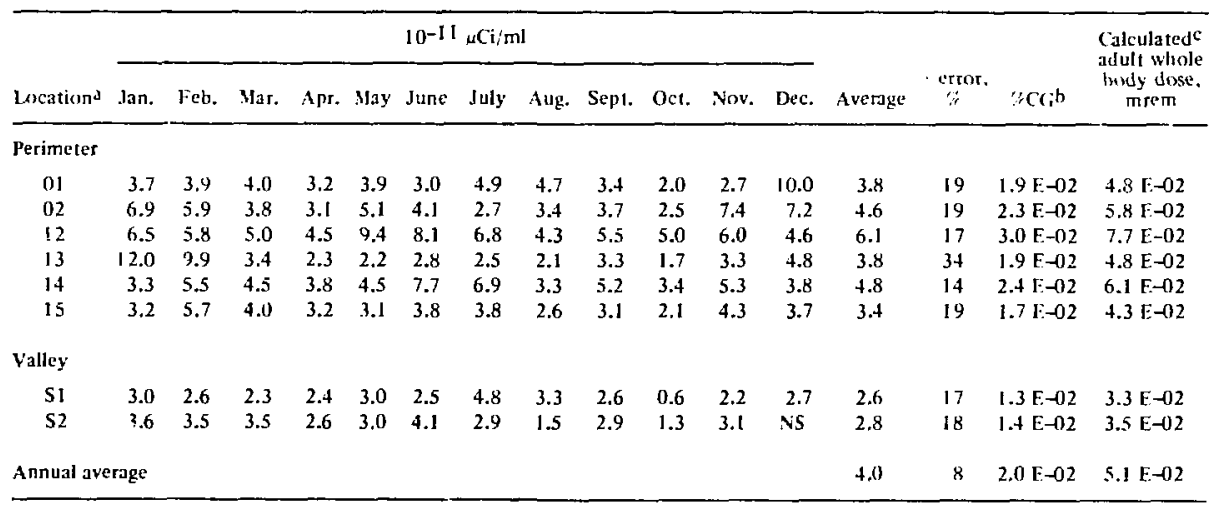

asee Figs. 3 and 4 for sampling locations.

${ }^{\mathrm{b}} \mathrm{CG}=2.0 \mathrm{E}-07 \mu \mathrm{Ci} / \mathrm{ml}$ for tritium (HTO) in air.

CDoses are calculated using the methods in U.S. NRC Regulatory Guide I.109 unless otherwise stated. 
TABLE 11. Concentrations of various radionuclides in the Livermore Valley soil samples during 1979.

\begin{tabular}{|c|c|c|c|c|c|c|}
\hline \multirow[b]{2}{*}{ Location ${ }^{a}$} & \multirow{2}{*}{$\begin{array}{l}\text { Sampling } \\
\text { depth, cm }\end{array}$} & \multicolumn{3}{|c|}{${ }_{\mu \mathrm{Ci}} / \mathrm{ary}_{\mathrm{g}} \cdot 20 \%$} & \multicolumn{2}{|c|}{$\mu \mathrm{g} / \mathrm{dry} \mathrm{g} \cdot 20 \%$} \\
\hline & & $239 \mathrm{Pu}\left(10^{-9}\right)$ & $40_{K}\left(10^{-5}\right)$ & $137 \mathrm{Cs}\left(10^{-7}\right)$ & $232 \mathrm{Th}$ & $238 C^{\circ}$ \\
\hline 726 & $0-5$ & $11.3+7$ & $1.3+7$ & $0.7 \cdot 19$ & $6.4: 1 !$ & $2.0 \cdot 70$ \\
\hline 727 & $0-5$ & $2.6 \cdot 11$ & $0.9 \pm 13$ & $0.5 \div 13$ & $7.5 \cdot 9$ & $1.7 \cdot 37$ \\
\hline 728 & $0-5$ & $2.7 \cdot 11$ & $1.4 \cdot 12$ & $2.3+7$ & $7.3 \cdot 10$ & $3.8 \cdot 26$ \\
\hline 729 & $0-5$ & $6.7 \cdot 7$ & $1.2+10$ & $4.4 \cdot 4$ & $4.9 \cdot 10$ & $2.4 \cdot 37$ \\
\hline $730^{\mathrm{h}}$ & $0-5$ & $1.5-12$ & $1.1+9$ & $0.3-24$ & $3.9 \cdot 10$ & $2.4=21$ \\
\hline 731 & $0-5$ & $9.5 \cdot 6$ & $1.1+10$ & $0.7 \cdot 14$ & $6.1+9$ & $3.9 \cdot 19$ \\
\hline 732 & $0-5$ & $3.0-9$ & $1.0 \cdot 9$ & $0.6+17$ & $5.5 \cdot 15$ & $2.1 \cdot 42$ \\
\hline 733 & $0-5$ & $8.5 \cdot 6$ & $1.7 \cdot 10$ & $4.9 \cdot 5$ & $5.3 \cdot 13$ & $2.6 \cdot 25$ \\
\hline 734 & $0-5$ & $7.6 \cdot 6$ & $1.4: 9$ & $3.6+5$ & $6.0 \cdot 11$ & $2.5 \cdot 36$ \\
\hline 735 & $0-5$ & $2.8: 9$ & $1.1 \cdot 12$ & $1.3 \cdot 10$ & $4.8 \cdot 13$ & $2.0 \cdot 100$ \\
\hline 736 & $0-5$ & $3.3 \cdot 9$ & $1.7 \cdot 9$ & $1.8 \cdot 8$ & $7.0 \cdot 8$ & $2.9 \cdot 22$ \\
\hline 737 & $0-5$ & $3.5 \cdot 9$ & $0.8 \cdot 10$ & $2.0 \cdot 7$ & $4.0 \cdot 12$ & $2.1 \cdot 32$ \\
\hline $738^{b}$ & $0-5$ & $2.8+9$ & $0.9 \cdot 13$ & $1.6 \cdot 8$ & $4.5 \cdot 12$ & $1.7 \cdot 25$ \\
\hline 739 & $0-5$ & $2.4 \cdot 8$ & $0.6 \cdot 9$ & $1.9 \cdot 7$ & $3.7 \cdot 15$ & $1.0 \cdot 41$ \\
\hline 740 & $0-5$ & $2.2 \cdot 8$ & $0.9+9$ & $0.8 \cdot 14$ & $4.8 \cdot 15$ & $2.0 \cdot 53$ \\
\hline 741 & $0-5$ & $15.5 \cdot 4$ & $1.4 \cdot 7$ & $7.7 \cdot 4$ & $6.0 \cdot 11$ & $3.0 \cdot 90$ \\
\hline 742 & $0-5$ & $3.0+6$ & $1.2+6$ & $1.8 \cdot 22$ & $6.0 \cdot 11$ & $2.1 \cdot 41$ \\
\hline 743 & $0-5$ & $1.8+7$ & $1.6: 7$ & $1.1-14$ & $6.7 \cdot 13$ & $3.0 \cdot 66$ \\
\hline $7+4$ & $0-5$ & $0.5 \pm 24$ & $1.8 \cdot 7$ & $0.4+34$ & $6.5 \cdot 12$ & $3.0 \cdot 55$ \\
\hline 745 & $0-5$ & $3.9 \cdot 6$ & $1.0: 8$ & $1.6: 9$ & $5.0 \cdot 15$ & $1.6 \cdot 41$ \\
\hline $746^{\prime \prime}$ & $0-5$ & $2.3 \cdot 8$ & $1.0 \cdot 6$ & $1.0 \cdot 12$ & $5.7 \cdot 13$ & $2.0 \cdot 60$ \\
\hline 747 & $0-5$ & $1.1=11$ & $1.2=12$ & $0.5 \cdot 20$ & $60-15$ & $=0.9 \cdot 100$ \\
\hline 748 & $0-5$ & $5.6+6$ & $1.2 \cdot 16$ & $2.8 \cdot 7$ & $6.7 \cdot 14$ & $2.0 \cdot 38$ \\
\hline $779^{c}$ & $0-5$ & $0.7=18$ & $1.4-16$ & $0.5 \cdot 18$ & $5.3 \cdot 12$ & $2.3 \cdot 33$ \\
\hline $780^{\mathrm{C}}$ & $0-5$ & $6.2 \cdot 8$ & $1.7 \cdot 4$ & $3.6 \cdot 5$ & $6.1 \cdot 9$ & $3.0 \cdot 98$ \\
\hline $781^{\mathrm{c}}$ & $0-5$ & $1.8=13$ & $1.2+18$ & $1.0 \cdot 12$ & $5.9 \cdot 11$ & $2.5 \cdot 25$ \\
\hline
\end{tabular}

asce Fig. 7 for sampling locations.

bReplicate $239 \mathrm{Pu}$ analysis results from aliquots of these samples are as follows:

$730 \mathrm{~A} \quad 1.4 \mathrm{~F}-09 \cdot 12 \%$

$738 \mathrm{~A} 2.7 \mathrm{~F}-09 \cdot 9 \%$

$746 \mathrm{~A} 2.8 \mathrm{~F}-09 \cdot 11 \%$

cThese samples represent a resampling of the Patterson Pass region.

TABLE 12. Plutonium. cesium, and uranium concentration in Site 300 soil samples during 1979.

\begin{tabular}{|c|c|c|c|c|c|}
\hline \multirow[b]{2}{*}{ Location 3} & \multirow{2}{*}{$\begin{array}{c}\text { Sompling } \\
\text { Jeptls, } \\
\text { cm }\end{array}$} & \multicolumn{2}{|c|}{ 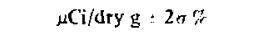 } & \multicolumn{2}{|c|}{$\mu g i d r y g \cdot 2 o$} \\
\hline & & ${ }^{239} \mathrm{Pu}\left(10^{-9}\right)$ & $137 \mathrm{Cs}\left(10^{-7}\right)$ & $235 \mathrm{~L}\left(10^{-2}\right)$ & $238 \mathrm{C}$ \\
\hline 749 & $0-5$ & $3.6 \pm 6$ & $2.0: 8$ & $1.5 \cdot 2$ & $2.1 \cdot 2$ \\
\hline 750 & $0-5$ & $6.0 \pm 5$ & $3.5+7$ & $1.2 \cdot 2$ & $1.7 \cdot 2$ \\
\hline 751 & $0-5$ & $7.1:^{\circ}$ & $3.7: 6$ & $1.2+2$ & $1.7 \cdot 2$ \\
\hline 752 & $0-5$ & $0.3 \cdot 32$ & $0.2+67$ & $1.8 \cdot 2$ & $2.9 \cdot 2$ \\
\hline 753 & $0-5$ & $3.2 \div 10$ & $1.4 \cdot 10$ & $3.7 \cdot 1$ & $14.0 \cdot 2$ \\
\hline $754^{b}$ & $0-5$ & $2.0 \div 12$ & $1.2 \cdot 10$ & $1.7 \cdot 2$ & $2.4+1$ \\
\hline 755 & $0-5$ & $4.3 \pm 9$ & $2.2 \cdot 7$ & $1.3 \cdot 2$ & $2,0 \cdot 1$ \\
\hline 756 & $0-5$ & $5.1 \div 9$ & $2.6: 7$ & $1.3 \cdot 2$ & $1,9,1$ \\
\hline 757 & $0-5$ & $4.4: 11$ & $3.1 \cdot 7$ & $37.6 \cdot 1$ & $195.0 \cdot 2$ \\
\hline 758 & $0-5$ & $4.3 \cdot 8$ & $2.4+6$ & $1.5 \cdot 2$ & $2.2+2$ \\
\hline 759 & $0-5$ & $7.1+7$ & $4.3 \cdot 5$ & $1.3 \cdot 2$ & $2.0 \cdot 1$ \\
\hline $778^{b}$ & $0-5$ & $40.0+4$ & $5.3 \cdot 4$ & $1.4: 2$ & $2.7 \cdot 2$ \\
\hline $782 \mathrm{c}$ & $0-5$ & $11.8 \cdot 7$ & $4.0+5$ & $1.4+2$ & $2.5 \cdot 2$ \\
\hline
\end{tabular}

aSee Fig. 8 for sampling locations.

bReplicate $239 \mathrm{Pu}$ analysis results from aliquots of these samples are as follows: $754 \mathrm{~A} \quad 1.9 \mathrm{~F}-09 \cdot 12 \%$

778 A $37,01:-09+5 \%$.

cSample 782 is a replicate sample taken from the same location as sample 778 . 
TABLE 13. Comparison of various radionuclides in LLL and Livermore Water Reclamation Plant effluents during 1979.

\begin{tabular}{|c|c|c|c|c|c|c|}
\hline & \multicolumn{2}{|c|}{$\mathrm{HTO}, \mu \mathrm{Ci} ; \mathrm{ml}$} & \multicolumn{2}{|c|}{137 's. $\mu \mathrm{Ci}$ ml $\cdot 2 s^{\prime} ;$} & \multicolumn{2}{|c|}{$239 \mathrm{Pu}, \mu \mathrm{Ci} \mathrm{ml}=2 \sigma$} \\
\hline & $10-5$ & $10^{-6}$ & $10^{-10}$ & $10^{-11}$ & $10^{-9}$ & $10^{-12}$ \\
\hline Yonth & L.L.L & LHRP & LLL & LHRP & LLL. & LWRP \\
\hline Ian. & 0.5 & 0.8 & $15.1 \cdot 4$ & $2.0 \cdot 86$ & $17.9-6$ & $17.0=9$ \\
\hline Fels. & 0.3 & 0.7 & $3.4 \cdot 8$ & $2.0 \cdot 85$ & $1.8 \cdot 4$ & $4.8=17$ \\
\hline Mar. & 0.4 & 0.6 & $7.7 \cdot 5$ & $7.0 \cdot 28$ & $2.2 \cdot 7$ & $5.0 \cdot 23$ \\
\hline tpr. & 0.7 & 0.8 & $7.4 \cdot 6$ & $6.0 \cdot 36$ & $5.9 \cdot h$ & $1.2=36$ \\
\hline itay & 1.1 & 1.4 & $\mathrm{Ni}$ & $10.0 \cdot 47$ & $0.9 \cdot 5$ & $0.5=60$ \\
\hline Iune & 2.2 & 2.2 & $\therefore i$ & $7.0 \cdot 25$ & $1.6 \cdot 6$ & $33.0: 10$ \\
\hline Iuly & 0.5 & 0.9 & $6.7 \cdot 7$ & $7.0 \cdot 18$ & $2.5 \cdot 5$ & $1.9 \cdot 16$ \\
\hline hug. & 2.3 & 3.6 & $5.1 \cdot 12$ & $7.0 \cdot 23$ & $0.8 \cdot 5$ & $1.3: 23$ \\
\hline Supt. & 3.5 & 1.7 & $3.3 \cdot 8$ & $6.0 \cdot 19$ & $0.4 \cdot 4$ & $1.7 \cdot 19$ \\
\hline Oct. & 0.9 & 4.7 & $5.6 \cdot 4$ & $7.0 \cdot 20$ & $0.7 \cdot 5$ & $0.7=43$ \\
\hline Nor. & 8.9 & 6.0 & $11.7 \cdot 3$ & $17.0 \cdot 12$ & $1.1 \cdot 6$ & $3.3 \cdot 18$ \\
\hline Dec. & 3.0 & 2.5 & $5.7 \cdot 6$ & $16.0 \cdot 14$ & $0.3 \cdot 5$ & $2.8=22$ \\
\hline Annual average & $2.0 \mathrm{r}-0.05$ & $2.2 \mathrm{~F}-0 \mathrm{~h}$ & $7.2 \mathrm{~F}-10$ & $7.8 \mathrm{~F}-11$ & $3.0+-09$ & 6.1 $:-12$ \\
\hline - error, : & 69 & 47 & 33 & 34 & 95 & 91 \\
\hline$c i$ & $1.0 \mathrm{f}-01$ & $3.0 \mathrm{~F}-03$ & $4.01-0 \mathrm{H}$ & $2,01-05$ & $1.0 E-04$ & $5.0 \mathrm{E}-06$ \\
\hline$\because c c$ & $2.0+-02$ & $7.3 \mathrm{~F}-6.2$ & $1.8 \mathrm{l}:-0.4$ & $3.9 \mathrm{~F}-04$ & $3.0 \mathrm{~F}-03$ & $1.2 \mathrm{~F}-04$ \\
\hline
\end{tabular}


TABLE 14. Gross alpha activity in water samples from the Livermore Valley during 1979.

\begin{tabular}{|c|c|c|c|c|c|c|}
\hline \multirow[b]{2}{*}{ Location ${ }^{3}$} & \multirow{2}{*}{$\begin{array}{c}\text { Number } \\
\text { of samples }\end{array}$} & \multicolumn{3}{|c|}{$10^{-9} \mu \mathrm{Ci} / \mathrm{ml}$} & \multirow[b]{2}{*}{$=$ error, $\%$} & \multirow[b]{2}{*}{$\% \mathrm{CG}^{\mathbf{b}}$} \\
\hline & & Maximum & Minimum & Average & & \\
\hline 11 & 4 & 3.3 & 0.3 & 2.0 & 65 & 6.8 \\
\hline 13 & 6 & 2.5 & 0.3 & 1.3 & 55 & 4.3 \\
\hline 15 & 4 & 2.1 & 0.3 & 1.2 & 79 & 4.1 \\
\hline 16 & 4 & 4.5 & 0.3 & 1.8 & 106 & 5.9 \\
\hline 19 & 4 & 2.3 & 0.3 & 1.0 & $8 i$ & 3.5 \\
\hline 20 & 3 & 5.0 & 0.3 & 1.9 & 175 & 6.5 \\
\hline 24 & 4 & 3.6 & 0.4 & 1.8 & $90^{\circ}$ & 5.9 \\
\hline 26 & 4 & 1.9 & 0.3 & 0.9 & 7. & 3.1 \\
\hline 29 & 4 & 1.9 & 0.1 & 0.6 & 138 & 2.1 \\
\hline
\end{tabular}

aSee Fig. 4 for sampling locations.

hCG $=3.0 \mathrm{E}-08 \mu \mathrm{Ci} / \mathrm{ml}$ for gross alpha in water.

TABLE 1s. Fross alpha activity in water samples from Site 300 during 1979.

\begin{tabular}{|c|c|c|c|c|c|c|}
\hline \multirow[b]{2}{*}{ Locationa } & \multirow{2}{*}{$\begin{array}{l}\text { Number } \\
\text { of samples }\end{array}$} & \multicolumn{3}{|c|}{$10^{-9} \mu \mathrm{Ci} / \mathrm{mI}$} & \multirow[b]{2}{*}{ \pm error, $\%$} & \multirow[b]{2}{*}{$\% \mathrm{CG} b$} \\
\hline & & Maximum & Minimum & Average & & \\
\hline 01 & 4 & 3.9 & 0.4 & 2.3 & 71 & 7.7 \\
\hline 02 & 4 & 5.3 & 0.7 & 3.0 & 72 & 10.0 \\
\hline 03 & 4 & 11.2 & 0.2 & 3.9 & 129 & 13.0 \\
\hline $04^{c}$ & 3 & 80.2 & 2.6 & 32.3 & 150 & $108.0^{\mathrm{c}}$ \\
\hline 05 & 4 & 4.5 & 0.5 & 2.6 & 63 & 8.7 \\
\hline 06 & 4 & 4.5 & 0.2 & 1.7 & 119 & 5.7 \\
\hline 07 & 4 & 5.0 & 0.2 & 2.5 & 105 & 8.3 \\
\hline 11 & 3 & 5.2 & 0.4 & 2.3 & 130 & 7.7 \\
\hline 14 & 2 & 7.0 & 0.2 & 3.6 & 200 & 12.0 \\
\hline 20 & 2 & 2.2 & 1.0 & 1.6 & 79 & 5.3 \\
\hline 21 & 2 & 0.7 & 0.3 & 0.5 & 91 & 1.7 \\
\hline
\end{tabular}

asee Figs. 5 and 6 for sampling locations.

${ }^{b} \mathrm{CG}=3.0 \mathrm{E}-0.8 \mu \mathrm{Ci} / \mathrm{ml}$ for gross alpha activity in water.

eSpecific analyses of these samples demonstrate that all the activity is Jue to naturally occurring uranium, for which the corcentration guide value is $2.0 \mathrm{E}-05 \mu \mathrm{Ci} / \mathrm{ml}$. 
TABLE 16. Gross beta activity in water samples from the Livermore Valley during 1979.

\begin{tabular}{|c|c|c|c|c|c|c|}
\hline \multirow[b]{2}{*}{ Locationa } & \multirow[b]{2}{*}{ Number of samiples } & \multicolumn{3}{|c|}{$10^{-9} \mu \mathrm{Cj} / \mathrm{ml}$} & \multirow[b]{2}{*}{ \pm enor, $\%$} & \multirow[b]{2}{*}{$\% \mathrm{CGb}$} \\
\hline & & Maximum & Minimin & Average & & \\
\hline 11 & 4 & 12.0 & 2.6 & 6.7 & 66 & 2.2 \\
\hline 13 & 5 & 6.2 & ng & 2.7 & 71 & 0.9 \\
\hline 15 & 4 & 7.0 & 0.3 & 3.9 & 71 & 1.3 \\
\hline 16 & 4 & 14.2 & 4.8 & 8.5 & 50 & 2.8 \\
\hline 19 & 4 & 5.0 & 0.8 & 3.6 & 53 & 1.2 \\
\hline 20 & 3 & 21.3 & 1.2 & 8.0 & 168 & 2.7 \\
\hline 24 & 4 & 8.4 & 5.1 & 6.5 & .23 & 2.2 \\
\hline 26 & 4 & 15.1 & 3.2 & 7.8 & 72 & 2.6 \\
\hline 29 & 4 & 8.0 & 2.1 & 5.1 & 58 & 1.7 \\
\hline
\end{tabular}

aSee Fig. 4 for sampling locations.

$\mathrm{b}_{\mathrm{CG}}=3.0 \mathrm{E}-07 \mu \mathrm{Ci} / \mathrm{ml}$ for gross beta activity in water. The $\mathrm{CC}$; for $\mathrm{S}_{\mathrm{S}} \mathrm{S}$ is used for these analyses.

TABLE 17. Gross beta activity in water samples from Site 300 during 1979.

\begin{tabular}{|c|c|c|c|c|c|c|}
\hline \multirow[b]{2}{*}{ Location ${ }^{a}$} & \multirow[b]{2}{*}{ Number of samples } & \multicolumn{3}{|c|}{$10^{-9} \mu \mathrm{Cl} / \mathrm{ml}$} & \multirow[b]{2}{*}{ - enror, $\not r$} & \multirow[b]{2}{*}{$\% \mathrm{CG}^{\mathrm{b}}$} \\
\hline & & Maximum & Minimum & Average & & \\
\hline 01 & 4 & 6.3 & 5.2 & 5.7 & 9 & 1.9 \\
\hline 02 & 4 & 10.6 & 3.5 & 8.2 & 40 & 2.7 \\
\hline 03 & 4 & 30.0 & 9.0 & 14.7 & 69 & 4.9 \\
\hline 04 & 3 & 29.4 & 16.7 & 21.0 & 40 & 7.0 \\
\hline 05 & 4 & 11.8 & 7.1 & 10.0 & 21 & 3.3 \\
\hline 06 & 4 & 6.5 & 4.2 & 5.7 & 18 & 1.9 \\
\hline 07 & 4 & 20.4 & 8.5 & 12.0 & 47 & 4.0 \\
\hline 11 & 3 & 9.9 & 2.9 & 7.0 & 60 & 2.3 \\
\hline 14 & 2 & 9.7 & 6.0 & 7.9 & 47 & 2.6 \\
\hline 20 & 2 & 6.0 & 5.5 & 5.8 & 10 & 1.9 \\
\hline 21 & 2 & 15.2 & 12.0 & 13.6 & 24 & 4.5 \\
\hline
\end{tabular}

aSee Figs. 5 and 6 for sampling locations.

${ }^{b} \mathrm{CG}=3.0 \mathrm{E}-07 \mu \mathrm{Ci} / \mathrm{ml}$ for gross activity in water. The CG, for ${ }^{90} \mathrm{Sr}$ is used for these analyses. 
TABLE 18. Tritium (HTO) in water samples from tle Livermore Valley during 1979.

\begin{tabular}{|c|c|c|c|c|c|c|c|}
\hline \multirow[b]{2}{*}{ Locationa } & \multirow{2}{*}{$\begin{array}{l}\text { Number } \\
\text { of samples }\end{array}$} & \multicolumn{3}{|c|}{$10^{-7} \mu \mathrm{Ci} / \mathrm{ml}$} & \multirow[b]{2}{*}{ - etrur. $\%$} & \multirow[b]{2}{*}{$\mathrm{HCO}$} & \multirow{2}{*}{$\begin{array}{c}\text { Calculated adult } \\
\text { shole bedy dose. } \\
\text { mrem }\end{array}$} \\
\hline & & Maximum & Minimum & Average & & & \\
\hline 11 & 4 & 1.4 & 1.2 & 1.3 & 7 & $4.3 \mathrm{~F}-03$ & $1.0 \mathrm{E}-02$ \\
\hline 15 & 4 & 1.4 & 1.2 & 1.4 & 8 & $4.7 \mathrm{E}-03$ & $1.0 \mathrm{E}-102$ \\
\hline 16 & 4 & 3.0 & 1.7 & 2.3 & 27 & $7.7[-03$ & $1.8 \mathrm{E}-1) 2$ \\
\hline 19 & 4 & 1.3 & 0.3 & 0.9 & 48 & $3.0 \mathrm{E}-03$ & $6.9:-03$ \\
\hline 20 & 6 & 25.6 & 3.0 & 11.6 & 57 & $3.9 \mathrm{E}-1) 2$ & $8.9 \mathrm{E}-02$ \\
\hline 24 & 4 & 2.7 & 1.9 & 2.4 & 15 & $8.0 \mathrm{~F}:-103$ & $\mid x \Leftarrow-02$ \\
\hline 26 & 4 & 3.1 & 2.9 & 3.0 & 4 & $1.0 \mathrm{~F}-02$ & $2.3 \mathrm{E}-02$ \\
\hline 29 & 4 & 1.3 & 1.1 & 1.2 & 7 & $4.0 \mathrm{E}-03$ & $9.2 \mathrm{E}-103$ \\
\hline 30 & 10 & 1.6 & 1.2 & 1.4 & 5 & $4.7 \mathrm{~F}-403$ & $1.1 \mathrm{E}-(02$ \\
\hline
\end{tabular}

aSec Fig. 4 tor sampling location.

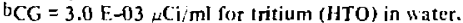

TABLE 19. Tritium (HTO) in water sumples from Site 300 during 1979.

\begin{tabular}{|c|c|c|c|c|c|c|c|}
\hline \multirow[b]{2}{*}{ Locationa } & \multirow{2}{*}{$\begin{array}{l}\text { Number } \\
\text { of sampies }\end{array}$} & \multicolumn{3}{|c|}{$10^{-8} \mu \mathrm{Ci}, \mathrm{ml}$} & \multirow[b]{2}{*}{ - ctrar.:: } & \multirow[b]{2}{*}{$\because \mathrm{Cl}^{b}$} & \multirow{2}{*}{$\begin{array}{c}\text { Calculated adult } \\
\text { "hole beidy dose. } \\
\text { mirem }\end{array}$} \\
\hline & & Maximum & Minimum & Average & & & \\
\hline (j) 1 & + & 4.5 & 2.6 & 3.4 & 25 & $1.1 \mathrm{~F}-1) 3$ & $2.6 \mathrm{~F}-1) 2$ \\
\hline 02 & 3 & 5.5 & 4.1 & 4.8 & 17 & $1.6 \mathrm{~F}-133$ & $3.6 \mathrm{E}-02$ \\
\hline 03 & 4 & 4.0 & 2.5 & 3.2 & 23 & $1.1(-1) 3$ & $2+\mathrm{F}-102$ \\
\hline 04 & 3 & 4.8 & 3.1 & 3.9 & 26 & $1.3 \mathrm{E}-03$ & $3.0 \mathrm{E}-\mathrm{-1} 2$ \\
\hline 05 & 4 & 6.5 & 4.0 & 5.4 & 20 & $1.8 \mathrm{E}-03$ & $4.2 \mathrm{E}-02$ \\
\hline 06 & 4 & 4.5 & 1.2 & 3.1 & 45 & $1 .(1):-1) 3$ & $2.4 \mathrm{E}-4) 2$ \\
\hline 07 & 4 & 5.2 & 3.1 & 4.6 & 22 & $1.5 \mathrm{~F}-103$ & $3.5 \mathrm{~F}-02$ \\
\hline 11 & 3 & 6.4 & 4.5 & 5.5 & 20 & $1.81-(1) 3$ & $4.2 \mathrm{I}-02$ \\
\hline 14 & 2 & 12.0 & 7.5 & 9.8 & 46 & $3.3 E-1) 3$ & $7.5 \mathrm{l}:-02$ \\
\hline 20 & 6 & 22.5 & 0.8 & 8.3 & 78 & $2.8 \mathrm{~F}-113$ & $6.3 \mathrm{~V}-02$ \\
\hline 21 & 2 & 4.2 & $\$ .2$ & 4.2 & 1 & $1 .+1-4) 3$ & $3.21-402$ \\
\hline
\end{tabular}

aSee Figs. 5 and 6 for sampling locations.

$\mathrm{b}_{\mathrm{CG}}=3.0 \mathrm{E}-03 \mu \mathrm{Ci} ; \mathrm{ml}$ for tritium (HTO) in water. 
TABLE 20. Tritium (HTO) in groundwater samples from the Livermore Valley during 1979.

\begin{tabular}{|c|c|c|c|c|}
\hline Location & $\begin{array}{c}\text { Well } \\
\text { identification }\end{array}$ & "ll cll deptll, mI & $\begin{array}{c}\text { Activity } \\
{\left[7^{-6} \mu(\mathrm{i} / \mathrm{m}]\right.}\end{array}$ & $\ddot{H C(; b)}$ \\
\hline I & $3 \mathrm{~S} / 1 \mathrm{E}-01 \mathrm{P} 2$ & 15 & 3.12 & $1.0 \mathrm{E}-01$ \\
\hline 2 & $3 \mathrm{~S} / \mathrm{IE}-02 \mathrm{P3}$ & 116 & 0.04 & $1.35-03$ \\
\hline 3 & $3 S / 1 E-02 R 1$ & 10 & 2.74 & $9.1 \mathrm{~F}-02$ \\
\hline 4 & $3 \mathrm{~S} / 1 \mathrm{I}:-07 \mathrm{~B} 2$ & 46 & 0.02 & 6.5 F- 04 \\
\hline 5 & 3S/1E-09G1 & 49 & 0.67 & $2.2 \mathrm{~F}-02$ \\
\hline 6 & $3 S / 1 E-10 A 2$ & 27 & 1.29 & $4.3 \mathrm{~F}-02$ \\
\hline 7 & $3 S / 1 \mathrm{E}:-|1 J|$ & 63 & 0.55 & $1.8 \mathrm{E}-02$ \\
\hline 8 & $3 \mathrm{~S} / \mid \mathrm{L}:-11 \mathrm{HI}$ & 92 & 0.11 & $3.7 \mathrm{E}-03$ \\
\hline 9 & $3 S^{\prime} 1 \mathrm{E}-12 \mathrm{Cl}$ & 82 & 0.16 & $5.3 \mathrm{~F}-03$ \\
\hline 10 & $3 S: 1 F:-12 D 2$ & 14 & 2.25 & $7.5 \mathrm{E}-02$ \\
\hline 11 & $3 \mathrm{~S} / 1 \mathrm{E}-12 \mathrm{G}]$ & 27 & 1.05 & $3.5 \mathrm{E}-02$ \\
\hline 12 & $3 \mathrm{~S} / 1 \mathrm{E}-12 \mathrm{HI}$ & 104 & 0.19 & $6.3 \mathrm{~F}-03$ \\
\hline 13 & $3 \mathrm{~S} / 1 \mathrm{E}-14 \mathrm{Fi}$ & 82 & 0.30 & $1.0 \mathrm{E}-02$ \\
\hline 14 & $3 S / 1 F-16]+2$ & 29 & 0.16 & $5.3 \mathrm{~F}-03$ \\
\hline 15 & $3 S_{1}^{\prime} 1 \mathrm{~F}-22 \mathrm{D} 2$ & 22 & 0.05 & $1.7 \mathrm{E}:-03$ \\
\hline 16 & $3 \mathrm{~S} / 2 \mathrm{~F}-01 \mathrm{P} 2$ & 44 & 0.0 & $2.3 \mathrm{l}:-03$ \\
\hline 17 & $3 \mathrm{~S} / 2 \mathrm{~F}-03 \mathrm{~K} 3$ & 18 & 0.09 & $3.0 \mathrm{E}-03$ \\
\hline 18 & $3 S_{i}^{\prime} 21:-1001$ & 13 & 0.20 & $6.7 \mathrm{E}-03$ \\
\hline 19 & $3 S / 2 F:-1|\wedge|$ & 20 & 0.18 & $6.0 \mathrm{E}-03$ \\
\hline 20 & $3 S-21:-14 \lambda$ & 36 & 0.18 & $6.0[:-03$ \\
\hline 21 & 3S: $2 \mathrm{~F}-14 \mathrm{~B} 4$ & 79 & 0.07 & $2.3 \mathrm{~F}-03$ \\
\hline 22 & $3 \mathrm{~S} / 2 \mathrm{~F}-22 \mathrm{~B}]$ & 17 & 0.25 & $8.3:-03$ \\
\hline
\end{tabular}

aSce Fig. 10 for sampling lacations.

$\mathrm{b}_{\mathrm{C}} \mathrm{C} ;=3.0 \mathrm{~F}-03 \mu \mathrm{Ci} / \mathrm{ml}$ for tritium (HTO) in water. 
TABLE 21. Tritium (HTO) in vegetation samples collected in the Livermore Valley during 1979.

\begin{tabular}{|c|c|c|c|c|c|c|}
\hline \multirow[b]{2}{*}{ Location ${ }^{3}$} & \multirow{2}{*}{$\begin{array}{l}\text { Number } \\
\text { of samples }\end{array}$} & \multicolumn{3}{|c|}{$10^{-6}, \mu \mathrm{Ci} / \mathrm{ml}$, water recovered } & \multirow{2}{*}{ = error. } & \multirow{2}{*}{$\begin{array}{c}\text { Calculated } \\
\text { adult whole } \\
\text { body dose. } \\
\text { mrem }\end{array}$} \\
\hline & & Maximum & Minimum & Average & & \\
\hline 04 & 10 & 1.5 & 0.5 & 0.9 & 23 & $8.0 \mathrm{~F}-02$ \\
\hline I 5 & 12 & 3.0 & 1.2 & 1.7 & 25 & $1.5 \mathrm{~F}-() !$ \\
\hline 16 & 10 & 0.9 & 0.2 & 0.7 & 17 & $6.0 \mathrm{E}-02$ \\
\hline 20 & 9 & 3.4 & 0.8 & 1.4 & 36 & 1.3 E -01 \\
\hline 21 & 10 & 1.7 & 0.9 & 1.2 & 13 & $1.1 \mathrm{E}-01$ \\
\hline 22 & 12 & 2.8 & 0.7 & 1.5 & 27 & $1.3 \mathrm{E}-01$ \\
\hline 23 & 5 & 17.8 & 1.7 & 5.8 & 104 & $5.2 \mathrm{~J}:-() \mathrm{I}$ \\
\hline 29 & 11 & 4.5 & 0.7 & 2.3 & 30 & $2.0 \mathrm{~F}-0 \mathrm{I}$ \\
\hline 30 & 12 & 2.1 & 0.7 & 1.3 & 19 & $1.1 \mathrm{~F} \leadsto \mathbf{i}$ \\
\hline 31 & 12 & 3.8 & 0.8 & 1.9 & 27 & $1.7 \mathrm{E}-101$ \\
\hline
\end{tabular}

aSee Fig. 4 for sampling lowations.

TABLE 22. Tritium (HTO) in vegetation samples collected from Site 300 during 1979.

\begin{tabular}{|c|c|c|c|c|c|c|}
\hline \multirow[b]{2}{*}{ Locotionia } & \multirow{2}{*}{$\begin{array}{l}\text { Number } \\
\text { of samples }\end{array}$} & \multicolumn{3}{|c|}{$10^{-7} \mu \mathrm{Ci}$ iml, water recovered } & \multirow{2}{*}{ - error } & \multirow{2}{*}{$\begin{array}{c}\text { Caw ilated } \\
\text { whole iody } \\
\text { botfy dose. } \\
\text { mrem }\end{array}$} \\
\hline & & Max:mum & Minimum & Average & & \\
\hline 0] & 11 & 12.3 & 4.1 & 6.8 & 20 & $6.1 F=-122$ \\
\hline 02 & (0) & 7.0 & 3.5 & 5.0 & 18 & $4 \leq \mathrm{F}-(12$ \\
\hline 03 & 12 & 7.8 & 2.9 & 5.8 & 14 & $5.2 \mathrm{E}-02$ \\
\hline 05 & 9 & 16.1 & 2.0 & 6.7 & 40 & $6.0 \mathrm{l}:-02$ \\
\hline 06 & 10 & 26.8 & 4.9 & 10.1 & 39 & $9.0 \mathrm{E}-(1) 2$ \\
\hline 11 & 5 & 6.1 & 1.0 & 4.4 & +1 & $3.9 \mathrm{~F}-12$ \\
\hline 12 & 12 & 17.5 & 1.9 & 7.3 & $3 !$ & $6.5 \mathrm{t}-02$ \\
\hline 13 & 5 & 230.0 & 3.3 & 51.9 & 172 & $4.6 \mathrm{~F}-01$ \\
\hline
\end{tabular}

asee Figs. 5 and 6 for sampling locations. 
TABLE 23. Tritium (HTO in wine samples.

\begin{tabular}{|c|c|c|c|c|c|}
\hline \multirow[b]{2}{*}{ Location } & \multirow{2}{*}{$\begin{array}{l}\text { Number } \\
\text { of samples }\end{array}$} & \multicolumn{3}{|c|}{$10^{-6} \mu \mathrm{Ci} / \mathrm{ml}$, water recovered } & \multirow[b]{2}{*}{ erress."? } \\
\hline & & Maximun: & Minininuum & Average & \\
\hline Livermore Valtey & 16 & 0.69 & 0.10 & 0.42 & 16 \\
\hline Californiab & 11 & 0.16 & 0.07 & 0.11 & in \\
\hline Europe & 8 & 2.67 & 0.11 & 1.11 & 69 \\
\hline
\end{tabular}

a Samples represent vintages ranging from 1967 to 1978.

bexclading the I ivermore Valley region.

TABLE 24. Tritium (HTO) concentrition in honey samples collected in the Livermore Valley."

\begin{tabular}{|c|c|c|c|c|}
\hline \multirow{2}{*}{$\begin{array}{l}\text { Number } \\
\text { of samples }\end{array}$} & \multicolumn{3}{|c|}{$10^{-6}$ i $\mathrm{i} / \mathrm{ml}$, water recovered } & \multirow[b]{2}{*}{ ' crror. $\ddot{t}$} \\
\hline & Maximum & Minimum & Avetrge & \\
\hline 7 & 0.79 & 0.31 & 0.48 & 28 \\
\hline
\end{tabular}

The samples include loney from: 1978 and 1979 production years, and include de following variejes: mixed flower, starthistle, cream ef wildflower. safflower, mustard, eucaly F tus, and fall wildfower.

TABLE 25. Concentration of various radionucides il milk samples from the Livermore Valley duing 19?9.

\begin{tabular}{|c|c|c|c|}
\hline & $10^{-7} \mu \mathrm{Ci} / \mathrm{ml}$ & $10^{-6} \mu\left(\mathrm{i}_{4} \mathrm{nIi}\right.$ & $10^{-9}{ }_{\mu}(\mathrm{i} / \mathrm{ml}$ \\
\hline & HTO & $40)_{K}$ & $137 \mathrm{cs}$ \\
\hline Number of samples & 31 & 31 & 31 \\
\hline Mavimun & 9.3 & 2.1 & 7.1 \\
\hline Minimum & 2.1 & 1.3 & 0.8 \\
\hline Average & 5.4 & i. 6 & 3.6 \\
\hline + error." $"$ & 10 & 4 & 14 \\
\hline $\begin{array}{l}\text { Calculated adult } \\
\text { whole body dose, mrem }\end{array}$ & $1.81:-02$ & 20.3 & $8.01:-02$ \\
\hline
\end{tabular}


TABLE 26. Envirommental ridiation mensurements (TLD) at the LLL perimeter during 1979.

\begin{tabular}{cccccc}
\hline Locutioni & lan.-Mar. & Apr.-June & July-Sept. & Oct.-Dec. & Annua!h \\
\hline 1 & 15 & 17 & 15 & 13 & 60 \\
2 & 16 & 15 & 16 & 14 & 61 \\
3 & 16 & 15 & 15 & 15 & 61 \\
4 & 15 & 16 & 15 & 15 & 61 \\
$5^{\mathrm{t}}$ & 36 & 13 & 23 & 15 & 96 \\
6 & 15 & 15 & 16 & 13 & 62 \\
7 & 14 & 15 & 14 & 14 & 56 \\
8 & 13 & 16 & 14 & 13 & 56 \\
9 & 14 & 16 & 15 & 15 & 58 \\
10 & 16 & 18 & 17 & 15 & 65 \\
11 & 18 & 16 & 18 & 14.4 & 68 \\
12 & 18 & 15.9 & 15.6 & 67 \\
Average & 15.5 & & & 61.4 \\
\hline
\end{tabular}

asee Fig. 3 for sampling locations.

bTLD measurements in the off-site vicinity of the Laboratory (Fig. I 1) have a median annual background of 59 mrem. However, subtracting this value from the data above to estimate the contribution from Laboratory operations yields several negative contributions: tluss, demonstrating that background levels at various perimeter Incations eannot be represented by a single value.

CNeutron dosc measurements at location 5 indicate an additional annual dose of $80 \mathrm{mrem}$. The seven otice neutron monitoring loeations (see lig. 3 ) indicate an annual ayerage neutron dose of $12 \mathrm{mrem}$. 
TABLE 27. Concentration of heryllium on air filters at the LLL perineter during 1979.

\begin{tabular}{|c|c|c|c|c|c|c|c|c|c|c|c|c|c|c|}
\hline \multirow[b]{2}{*}{ I.rocationa } & \multicolumn{12}{|c|}{$10^{-5} \mu \mathrm{g} \mathrm{m}^{3}$} & \multirow[b]{2}{*}{ Averinge } & \multirow[b]{2}{*}{ - crmur. " } \\
\hline & Jan. & licb. & Mar. & Apr. & May & furic & July & Aug. & Sept. & oct. & Nov. & Dec. & & \\
\hline 01 & 1.3 & 1.7 & 1.6 & 1.7 & 3.8 & 3.6 & 2.7 & 1.7 & +.9 & 1.3 & 1.6 & 1.8 & 2.3 & 24 \\
\hline 02 & 1.9 & 1.6 & 1.8 & 1.5 & 2.4 & 3.1 & 2.4 & 1.5 & 3.0 & 1.5 & 2.3 & 2.2 & 2.1 & 15 \\
\hline 12 & 1.5 & 1.9 & 1.8 & 1.6 & 2.9 & 3.3 & 5.3 & 3.3 & 5.3 & $5 . t$ & 1.7 & 5.5 & 3.3 & 30 \\
\hline 13 & $1 . t$ & 1.6 & 1.6 & 1.6 & 1.2 & 1.7 & 2.5 & 1.5 & 1.7 & 1.4 & 1.7 & 1.6 & 1.6 & 11 \\
\hline 14 & 1.5 & 1.9 & 1.8 & 1.3 & 1.1 & 2.8 & 3.7 & 2.8 & 4.2 & 1.2 & 2.4 & 2.4 & 2.3 & 25 \\
\hline 15 & 1.4 & 1.5 & 1.5 & 1.5 & 1.2 & 3.1 & 2.6 & 1.6 & 3.2 & 1.2 & 1.6 & 1.8 & $1 . x$ & 22 \\
\hline Averege & 1.5 & 1.7 & 1.7 & 1.5 & 2.1 & 2.9 & 3.2 & 2.1 & 3.7 & 2.0 & 1.9 & 2.6 & 2.2 & 12 \\
\hline errot. $\theta$ & 11 & 6 & 6 & 7 & 44 & 19 & 30 & 32 & 30 & 68 & 16 & 46 & & \\
\hline$\because$ stundard & 0.15 & 0.17 & 0.17 & 0.15 & 0.21 & 0.29 & 0.32 & 0.21 & 0.37 & 0.20 & 0.14 & 0.26 & 0.22 & \\
\hline
\end{tabular}

aSee Fig. 3 for sampling locations.

bFenssion standard is $0.01 \mu \mathrm{g}, \mathrm{n} 3$. Jederal Register, $\mathrm{A}, \mathrm{ril} 6.1973$.

TABLE 28. Concentration of heryllim on air filters al Sita 300 durmg 1979.

\begin{tabular}{|c|c|c|c|c|c|c|c|c|c|c|c|c|c|c|}
\hline \multirow[b]{2}{*}{ Locationa' } & \multicolumn{12}{|c|}{$10^{-5}, m^{3} m^{3}$} & \multirow[b]{2}{*}{ Average } & \multirow[b]{2}{*}{ error, } \\
\hline & Ian. & F(b). & Mar. & Apr. & May & June & . Iuly & Aug. & Sept. & $O \mathrm{Cl}^{\prime}$ & Nor. & D心. & & \\
\hline 01 & 1.1 & I.I & 1.1 & 0.9 & i. 2 & 2.0 & 1.2 & 1.7 & 1.4 & 3.0 & 1.3 & 1.7 & 1.5 & 23 \\
\hline 02 & 1.1 & 1.2 & 1.1 & 1.0 & 1.2 & 2.9 & 2.4 & 2.0 & 1.3 & 3.6 & 1.5 & 1.4 & 1.7 & 28 \\
\hline 03 & 2.13 & 2.2 & 2.1 & 1.9 & 2.2 & 2.5 & 3.8 & 2.4 & 3.4 & 3.2 & 2.4 & $2 . \dot{n}$ & 2.6 & 14 \\
\hline 04 & 2.6 & $2 . !$ & 2.7 & 1.5 & 2.2 & 2.6 & 2.1 & 2.5 & 3.1 & $1 . x$ & 2.2 & 2.3 & 2.3 & 11 \\
\hline 05 & 1.4 & 1.5 & 1.3 & 1.3 & 4.5 & 5.5 & f.t & 2.3 & 3.4 & 3.8 & 1.5 & 1.5 & 2.7 & 33 \\
\hline 07 & 1.5 & $\mathrm{I} .5$ & 1.6 & 1.3 & 1.7 & 1.8 & 1.6 & 1.9 & $1 . x$ & 1.5 & 1.8 & 1.8 & I.6 & 6 \\
\hline 08 & 1.t & 1.6 & 1.9 & 1.3 & $1 . t$ & 2.0 & 1.4 & 1.5 & 1.8 & 1.4 & 1.8 & 1.7 & 1.6 & $s$ \\
\hline 189 & 1.9 & 2.1 & 2.0 & 1.6 & 2.5 & 1.9 & 1.3 & 2.9 & 3.5 & 1.6 & 1.5 & 1.4 & 2.0 & 14 \\
\hline I0 & 1.9 & 1.6 & 3.3 & 2.9 & 1.9 & 6.9 & 2.3 & 2.1 & 5.4 & 1.5 & 1.4 & 1.8 & 2.5 & 35 \\
\hline 11 & 6.3 & 1.6 & 1.5 & 1.3 & 3.2 & 4.1 & 1.6 & 1.9 & 1.4 & 1.6 & 2.6 & 2.1 & 2.4 & 3.7 \\
\hline Average & 2.1 & 1.7 & 1.4 & 1.5 & 2.0 & 3.2 & 2.2 & 2.1 & 2.7 & 2.3 & 1.8 & $1 . x$ & 2.1 & 4 \\
\hline error. : & +6 & 15 & 24 & 24 & 38 & 34 & 32 & 2 & 30 & 27 & 13 & 14 & & \\
\hline "is siandare & 0.21 & 0.17 & 0.19 & 17.15 & 0.20 & 0.32 & 0.22 & 0.21 & 0.27 & 0.23 & 0.18 & $1) !: ;$ & 0.21 & \\
\hline
\end{tabular}

aSee fig. 5 for sampling locations.

bemission standard is $0.01 \mu \mathrm{g} \mathrm{m} 3^{3}$. Veveral Regisier. April 6. 1973. 
TABLE 29. Atonthly average concentritioms of various elements in the LLL liquid effluent during 1979.

\begin{tabular}{|c|c|c|c|c|c|c|c|c|c|}
\hline Month & c d & Cir & Cis & $F$ & $\mathrm{Pl}$ & Ni & In & Zn & $F$ \\
\hline $\mathrm{Ja} \mathrm{n}$. & 0.02 & 0.36 & i.t & 7.3 & 0.04 & 0.12 & 0.22 & 0.98 & 0.12 \\
\hline Feb. & $0.11\}$ & 10.16 & 1.0 & 2.0 & 1.01́ & 0.02 & 0.12 & 0.29 & 0.18 \\
\hline Mar. & 0.112 & $0.6,5$ & 3.7 & $4 . .5$ & $1) .11 .5$ & 0.09 & 0.35 & 0.84 & $\mathbf{N A}$ \\
\hline Apr. & 0.01 & $(1,60)$ & 2.3 & 3.3 & 0.0 .3 & 0,07 & 0.23 & 0.56 & (0.13 \\
\hline Misy & 0.111 & 11.47 & 2.6 & 3.1 & 0.16 & 0.04 & 0.111 & $(1,64$ & 0.12 \\
\hline Jun: & $(i, 0)$ & 0.35 & 2.1 & 1.9 & 0.100 & 19.07 & $(1.011$ & 11.67 & (J.11) \\
\hline Jul! & $(1.1))$ & $0.2 k$ & 2.3 & 2.5 & 0.05 & $17.1 \%$ & $(1.0)$ & 1.16 & 0.11 \\
\hline Aug. & 0.111 & 1). 28 & 4.7 & 2,1 & 0.113 & 11.12 & $0.0 ?$ & 0.71 & 0.11 \\
\hline Sepl. & $1) .1\} 1$ & 0.16 & 3.6 & 1.7 & 0.22 & $0.0 \times$ & $\{1.23$ & $(1.60$ & 0.10 \\
\hline (bit. & io.tif & 0.14 & 3.4 & 2.4 & 0.10 & 11.11 & $(1.1) 5$ & $1) .70$ & $1) .14$ \\
\hline vis. & 0.011 & 0.33 & 2.5 & 1.4 & 0.117 & 11.04 & 0.01 & $1) .57$ & 0.07 \\
\hline $10 x$ & 11.111 & $1.2 x$ & 11.361 & 10.45 & 0.118 & 11.012 & 1).111 & $1 ? .41$ & 11.12 \\
\hline Avtrage & $\mid 1.1) \mid$ & 0.34 & 12 & $2 . x$ & $0.0 \mathrm{x}$ & $(1.1) 8$ & $11.1+$ & 10.68 & 1). 1 I \\
\hline · etruir, & 14 & 27 & 24 & 34 & 411 & 25 & htl & 201 & 19 \\
\hline
\end{tabular}

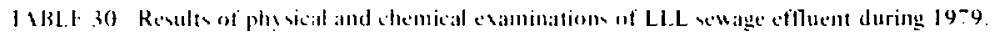

\begin{tabular}{|c|c|c|c|c|c|c|}
\hline \multirow[b]{2}{*}{ makn } & \multicolumn{6}{|c|}{ mg 1} \\
\hline & I.Mn-M:It. & Iprotunt. & Iuk-sopt. & (nt.-1)e. & Werage & - ertise. \\
\hline$[3(3)]$ & 1.1 & 54 & 413 & 102 & $6: i$ & 49 \\
\hline$(11)$ & 11 & $211 x$ & $1 \mathbf{S}^{7}$ & 267 & 221 & 22 \\
\hline lutal nitrogen t.14 V) & 3h & 23 & 32 & 34 & 34 & 15 \\
\hline 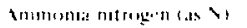 & $2 H$ & 21 & 27 & 31 & $2 \vec{i}$ & In \\
\hline vitrate nerogerntas & 1 & $(1.1)^{-}$ & $(1.0) 1$ & 11.14 & 0.14 & $y^{-}$ \\
\hline Sirsite merogen tas & 11.112 & $(1,0) 2$ & 0.131 & 10.131 & 0.01 & I \\
\hline 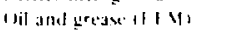 & 5 & 11 & 10 & $y$ & y & 30 \\
\hline sulfate & bi & +1 & 33 & $x^{-}$ & 67 & 24 \\
\hline tratills & 0.1102 & 0.0112 & 0.1012 & 0.0000 .5 & $(1.00) 2$ & 45 \\
\hline Buron & 1). & 11.72 & 1.13 & 0.9 & 0.9 & 17 \\
\hline (ynute & $>1$ & 0.47 & 0.19 & 0.28 & 0.5 & 99 \\
\hline Verout? & 0.12 & 0.001 & $3(10) 1$ & $(1.00) 2$ & 0.0 .3 & 148 \\
\hline xetcrium & 0.0005 & 0.00015 & (1. 1)06: & 0.01305 & 0.130005 & \\
\hline Intal alkslinuly & $12 x$ & 96 & 110 & IIh & 113 & 12 \\
\hline 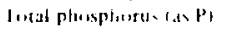 & 5.4 & 3.0 & 4.3 & 5.2 & 4.6 & 27 \\
\hline choride & 30 & 37 & 32 & 94 & 48 & 64 \\
\hline Pleconils & $\sqrt{ }$ & $11 .(10) ?$ & $(1.0) 3\}$ & 01.056 & 0.034 & II \\
\hline ( alciturt) & 11 & (11) & If: & 15 & 13 & 25 \\
\hline Vagnestum & 1.5 & 1.2 & $1 . x$ & 5.1 & 2.4 & 75 \\
\hline Mulume & 32 & 35 & $2 N$ & 72 & +2 & 48 \\
\hline Prectaniunt & 14 & in & $i=$ & $2 \vec{i}$ & 20 & 25 \\
\hline wodum tas in salement & 55 & 61) & +7 & 63 & 56 & 12 \\
\hline lolal silds & 221 & 32.3 & $2 x B$ & 452 & 321 & 30 \\
\hline [josuded solids & 1 & 234 & 211 & 376 & 274 & 38 \\
\hline suspented sostuds & $\therefore$ & 104 & hi: & 84 & \$6 & 26 \\
\hline Folante soldeds & 6.2 & $\ln 7$ & 119 & 170 & 130 & 39 \\
\hline 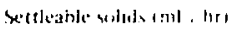 & 1 & 3.11 & 3.5 & 5 & 3.8 & 32 \\
\hline $\begin{array}{l}\text { Identifiable chlonnitted } \\
\text { hy drencarbens }\end{array}$ & 105 & I.tos & $10 s^{\mathrm{h}}$ & $1\left(J s^{-1)}\right.$ & & \\
\hline PCB(ppt) & 0.10 & 0.2 & 0.10 & 11.4 & (J.2 2 & $7 \mathrm{I}$ \\
\hline
\end{tabular}

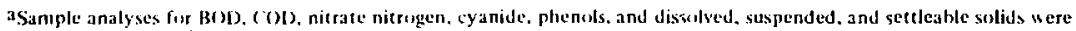
indaluertenti, nol perfiermed.

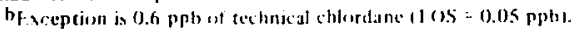


TABLE 31. Results of physical ind chemical examinations of the Site 300 sewage pond influent during 1970.

\begin{tabular}{|c|c|c|c|c|c|c|}
\hline \multirow[b]{2}{*}{ Analy sis } & \multicolumn{6}{|c|}{ nig I } \\
\hline & Ian-4lar. & ipr - - Juncia & Juty-Septa & $\left(\right.$ k.t.-1)ec. ${ }^{3}$ & Bwrape & artir. : \\
\hline Butl) & 113 & 1076 & 762 & 17 & 412 & $1 \div H$ \\
\hline (CH) & 262 & 156000 & 10634 & 249 & 6.737 & 115 \\
\hline lotal nutruger las & 17 & 364 & 213 & 15 & 152 & $1 ! !$ \\
\hline Lmmonsa murugen tas , & 13 & 14 & 25 & 5.1 & 22 & 77 \\
\hline Vitrate nitrogen (as & 0.5 & 0.1 & 0.1 & $13.1 \mathrm{H}$ & 0.113 & 111 \\
\hline ()il and grease (f 11 ) & 32 & 515 & $16 \mid 5$ & .5 & $5+2$ & i.34 \\
\hline Sultate & $14 x$ & $1+0$ & 23 & $\$+1)$ & $18 x$ & 44 \\
\hline irsenic & 0.002 & 0.033 & 0,004 & $0.006 x$ & 0.011 & 132 \\
\hline Buisun & 1.6 & 1.3 & 1.9 & 6. 2 & 2.4 & 84 \\
\hline Chanule & 0.112 & 0.01 & 0.001 & 0.001 & 0.006 & $y ?$ \\
\hline Herculst & 0.005 & 0.008 & 0.0001 & $\cdot 0.00431$ & 0.0014 & 92 \\
\hline Seleniun & $\cdot 0.0005$ & $\cdot 0.00005$ & $\cdot 0.10005$ & -0.0005 & - 0.000105 & \\
\hline lotal alkalımity & 123 & 617 & 480 & 493 & 553 & 65 \\
\hline Iriesl phospliciros & 5.1 & 55.2 & 44 & $X .6$ & 28 & 90 \\
\hline (nloride & 102 & 132 & K4 & 365 & 171 & 77 \\
\hline Plienesls & 0.11 & 0.12 & 0.12 & 0.011 & 0.09 & 60 \\
\hline Intal solids & 883 & 7547 & 10407 & $26 \times 2$ & 5380 & $\$ 1$ \\
\hline Dissolved solits & 753 & 1100 & 1110 & 2527 & 1373 & 57 \\
\hline Suspended solids & 73 & $34+0$ & 9943 & 50 & 3377 & 138 \\
\hline Vinatile solids & 200 & 5809 & 8128 & 420 & 3634 & 109 \\
\hline Scttiesble solids imt lihr) & 0.1 & 486 & 680 & $\cdot 0.1$ & 242 & 118 \\
\hline copper & 0.03 & 1.9 & 0.72 & 0.01 & 0.67 & 132 \\
\hline Vickel & 0.05 & 0.21 & 0.15 & 0.07 & 0.12 & 62 \\
\hline Zinc & 0.21 & 5.9 & 2.0 & 0.01 & 2.0 & 135 \\
\hline Cltromium & 0.02 & 0.5 & 0.4 .5 & 0.04 & 0.25 & 103 \\
\hline
\end{tabular}

aSamples were collected immediately upstream from the osidation pond inlet. Waste concentrations are clevated hecause of improper mixing at point of collection. 
TABLE 32. Estimated radiation dose to the public from LLL airborne effluents during 1979.

\begin{tabular}{|c|c|c|c|c|c|}
\hline Nuelide & Facility & Curies & $\begin{array}{l}\text { Dowe at }{ }^{\text {iz }} \\
\text { site boundary, } \\
\text { mren }\end{array}$ & $\begin{array}{c}\text { Dose to mearest } \\
\text { resident. } \\
\text { nurent }\end{array}$ & $\begin{array}{l}\text { Dose within } \\
\text { 80-km radius } \\
\text { of l.LL. } \\
\text { man-rem }\end{array}$ \\
\hline $41_{\mathrm{Ar}}$ & $\begin{array}{l}\text { Livermore pool } \\
\text { type reacter }\end{array}$ & 383 & 3.0 & 0.61 & 3.72 \\
\hline $3_{i 1}$ & Tritium facility & 4069 & 0.72 & 0.57 & 2.4 \\
\hline $3_{H}$ & $\begin{array}{l}\text { Insulat wg core } \\
\text { Iranster aceclera tor }\end{array}$ & 436 & 0.37 & 0.31 & 0.25 \\
\hline $13 x-150$ & $\begin{array}{l}\text { lilectron-pusition } \\
\text { linear acceleralor }\end{array}$ & 829 & 1.05 & 0.28 & 0.08 \\
\hline $\begin{array}{l}\text { Tistal annual } \\
\text { disse. mantrem }\end{array}$ & & & & & 3.45 \\
\hline
\end{tabular}

${ }^{3}$ Doses were calculated using CPS. the al touspheric diffusion code, with a correction for topengaphy.

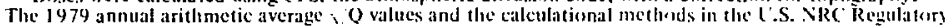
(iude 1.109 vere used to tetermine the desses to the public.

TABLE 33. Radiontetive effluent relcases from LLL from 1975 through 1979.

\begin{tabular}{|c|c|c|c|c|c|}
\hline \multirow[b]{2}{*}{ Yeitr } & \multicolumn{3}{|c|}{ Airborne eftuents, Ci } & \multicolumn{2}{|c|}{ Livuid efonents, $\mathrm{Ci}$} \\
\hline & $H_{A r}$ & $3 H$ & $13 y-150$ & HTO & $2391 \mathrm{Y}$ \\
\hline 1975 & 595 & 3384 & 1185 & 38 & $2.1 \mathrm{~F}-(1) 4$ \\
\hline 1976 & 470 & 3901 & 1035 & 10 & $1.5 \mathrm{~F}-64$ \\
\hline 1977 & 380 & 5210 & 990 & 13 & $3.6 \mathrm{~F}=0.4$ \\
\hline 1978 & 766 & 5362 & 1445 & 4 & X.6 $\mathrm{I}^{-04}$ \\
\hline 1979 & $3 \times 3$ & 4517 & 829 & 7 & $4.51-1) 4$ \\
\hline Average & 519 & 4492 & 1095 & 15 & $5.11-14.4$ \\
\hline
\end{tabular}

TABLE 34. Percent of concentration Luide of radionuclides detected in discharges to Liscrmorit i silnitary sewer system.

\begin{tabular}{|c|c|c|}
\hline Vuctideril & $\begin{array}{c}\text { (oncentration guide." } \\
+ \text { C }^{\prime} \mathrm{i} \text { m! }\end{array}$ & (c) \\
\hline 134 & $31-04$ & $1.1+-112$ \\
\hline $137 \%$ & $+1-0 t$ & S.5 1. $-\{1.3$ \\
\hline 110$)$ & (9) 1.04 & $3 . x 1-11.3$ \\
\hline $125 \mathrm{sh}$ & $31 \cdot-113$ & $1.11-11.3$ \\
\hline $95 \times$ & $31-03$ & $1.11-11.3$ \\
\hline Sfous & $41-113$ & $K .51-14$ \\
\hline $65 / \mathrm{n}$ & $3\{-0\}$ & $1.11-0.4$ \\
\hline $95 /$. & $21-113$ & $1.51-14$ \\
\hline (1) $(0)$ & $11-0.3$ & $3.4+-0.4$ \\
\hline
\end{tabular}

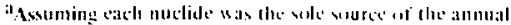

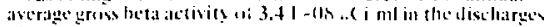

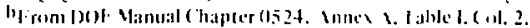


TABLE 35. Summary of various analyses for the Quality Assurance Program during 1979:1

\begin{tabular}{|c|c|c|c|c|c|c|c|}
\hline Isotope & Media & Quarter & LLL & EMtL & $A h^{b}$ & LLLIML & I.I.L. All \\
\hline \multirow[t]{4}{*}{$137 \mathrm{Cs}$} & Air & 1 & NS & NS & NS & & \\
\hline & & 2 & 1.60 & 1.32 & 1.31 & 1.21 & 1.22 \\
\hline & & 3 & 3.15 & 3.47 & 3.24 & 0.91 & 0.97 \\
\hline & & 4 & 1.68 & 1.30 & 1.41 & 1.29 & 1.19 \\
\hline \multirow[t]{4}{*}{${ }^{239} \mathrm{Pu}$} & Air & $\mathrm{I}$ & 5.50 & 5.30 & 5.76 & 1.04 & 0.95 \\
\hline & & 2 & 6.50 & 6.40 & 6.78 & 1.02 & 0.96 \\
\hline & & 3 & 2.75 & 2.4 .3 & 2.67 & 1.13 & 1.03 \\
\hline & & 4 & 5.95 & 6.00 & 6.16 & 0.99 & $(t .)^{-}$ \\
\hline \multirow[t]{4}{*}{${ }^{239} \mathrm{Pu}$} & Soil & $i$ & 7.10 & 8.10 & 7.10 & 0.88 & 1.00 \\
\hline & & 2 & 1.80 & 1.88 & 1.80 & 0.96 & 1.00 \\
\hline & & 3 & +.60 & 6.00 & 5.49 & 0.77 & $0.4+$ \\
\hline & & 4 & 1.50 & 1.35 & 1.42 & 1.11 & 1.06 \\
\hline \multirow[t]{4}{*}{$3 \mathrm{H}$} & Water & 1 & 1.34 & 1.24 & 1.24 & 1.08 & $1.0 \mathrm{x}$ \\
\hline & & 2 & 2.44 & 2.45 & 2.40 & 1.02 & 1.04 \\
\hline & & 3 & 3.16 & 3.04 & 3.07 & 1.04 & 1.03 \\
\hline & & 4 & 1.39 & 1.34 & 1.46 & 1.04 & 0.95 \\
\hline \multirow[t]{4}{*}{$239 \mathrm{Pu}$} & Wilter & 1 & 1.85 & 2.30 & 1.85 & 0.80 & 1.100 \\
\hline & & 2 & 5.40 & 9.00 & 5.84 & 0.60 & 0.92 \\
\hline & & 3 & 7.70 & 8.10 & 8.10 & 0.95 & 0.95 \\
\hline & & 4 & NS & XS & NS & & \\
\hline
\end{tabular}

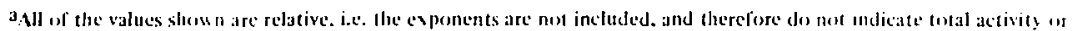
concentration levels.

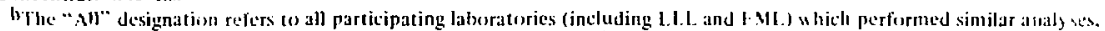
excluding only those values considered by F.ML to be statistical outliers. 


\section{APPENDIX B. DISCHARGE LIMITS TO \\ THE SANITARY SEWER SYSTEM \\ OF THE CITY OF LIVERMORE}

Sectiom 18.63 and 18.66 of the Code of the City of Livermore (1959) state the discharge limits for 1 isermure"s anitary sewer system. These limits are as follows:

Section 18.63

No perun shall discharge, or cause to be discharged, except for salt waste discharge from water wf tener unit of any kind or description installed and in operation on or before January 31, 1966, which are regeneraled by the ouner thereof at the place of use of such units, any of the following described water or "wates to any public ever unless the cuslomer obtains a permit from the city in accordance with Section 18.65.

(a) An! liquor or vapor having a lemperature higher than che hundred fifty degrees Fahrenheit.

(b) Any waters or wastes which contain more than lwo hundred ppm of fat, oil or grease that is perroleum ether soluble.

(c) Any ganoline, benzene, naphtha, luel oil or other inflammable or explosive liquid, solid or gas.

(d) Any garbage, excont properly ground with a mechanical garbage grinder. Specifically excluded from the sewers are wable products s. sulling from the handling, slorage and sale of fruits and vegetables from wher than retail produce extablishments, or other foods no intended primarily for immediate consumption.

(2) Aly ashes, cinders, sand, mud, straw, shavings, metal, glass, rags, feathers, tar, coal tar, aphalt. cemenl, plastics, woodh, paunch manure or any other solid viscous substance capable of causing obsiruction to the flow in sewer or other interferences with the proper economical operation of the sewage works.

(1) Ans wates or water with a pH lower than six and eight-tenths cr higher than eight.

(2) Ans waters or wastes containing cotal dissolved solid increments greater than three hundred and wenls-tive ppm, nur chlot ide increnems grealer than seventy-five $\mathrm{ppm}$, increase during a single cycle use of the waler supply.

(h) Any water or waster has ing a B.().D. greater than three hundred ppm (the average B.O.D. for roidemial maers).

(i) Any watcr or wastes containing more than three hundred $\mathrm{ppm}$ of suspended solids (the average -ispended solids for residential users).

(i) sul water intended to be used or uned to dilute wante discharge to avoid violation of the above limutallun (Order No. 586. palagraph J).

Secterm 19.6n

No person thall discharge or catese 1 ) be discharged any radioastive wastes into any public sewers. exceps where:

1. The waste is dincharged in uriet conformity with current Alomic Energy Commission recommendations for safe disposal of radioactive wastes.

B. The discharging of radioative waste will not cause ingury to personnel or damage to the sewer works. Am peron dincharging a radioative waste to a public sener in accordane w th the provisions of the preceding paragraph thall submil to the councit uch report as the council mat deem necesary.

In the went of an accidental spill of any radioactise materia! into the public sewer, the person respomible shall (a) momediately notify the plant superintendent, and (b) render such technical or other awsiance to the department of publit works within his power to prevent the sewage works from becoming comaminated ath radioactivity. 


\section{APTENDIX C. ENVIRONMENTAL ACTIVITY CONCENTRATION-GUIDE LEVELS}

The standards for Radiation Protection (DOE Manual Chapter 0524, issued March 3, 1977) state that the average activity of a mixture of radionuclides (whose identities and concentrations are unknown) in air and water should not exced the following vilues:
1. Air (controlled arta)
$6 \times 10^{-12} \mu \mathrm{Ci} ; \mathrm{ml}$
2. Air (uncontrolled area)
$2 \times 10^{-14} \mu \mathrm{Ci} / \mathrm{ml}$
3. Water (controlled area)
$4 \times 10^{-7} \mu \mathrm{Ciml}$
4. Water (uncontrolled areia)
$3 \times 10^{-k}{ }_{\mu} \mathrm{Ci} ; \mathrm{ml}$

If alpha enillers and ${ }^{277}$ Ac are delinitely not present, the follow ing salues maly be used wo determine permissible aserage activity:
5. Air (controlled aréa)
$\left.3 \times 10^{-11} \mu \mathrm{Ci} ; \mathrm{m}\right]$
6. Air (uncontrolled area)
$1 \times 10^{-12}{ }_{\mu} \mathrm{Ci}: \mathrm{ml}$

If ${ }^{129} \mathrm{l},{ }^{226} \mathrm{R}$ at, and ${ }^{22 h} \mathrm{R}$ a are definitely not present, the following values mat be used:
7. Walter (controlled area)
$3 \times 10^{-6} \mu \mathrm{Ciml}$
8. Water (uncontrolled area)
$1 \times 10^{-7} \mu \mathrm{Ci} \mathrm{ml}$

Both air and water samples are subjected to gross alpha and gross heta measurements. The average annual aipha ativities of samples may not exceed the activity values listed as $1-4$ above. Since the alpha emitters have heen accounied lor in the gross alpha measurements and the assuniption is made that $1291 .{ }^{227}$ Ac. ${ }^{22} R_{a 1}$, and ${ }^{2 x} R_{\text {it }}$ are not present in the samples, the average annual gross beta activities of the samples mas not exced the activities listed as 5-8 ahove. The assumption that ${ }^{129} \mathrm{I},{ }^{297} \mathrm{Ac}$. ${ }^{22} \mathrm{R}_{\mathrm{a}}$, and ${ }^{22 x} \mathrm{R}_{\mathrm{i}}$ are not present in air and uater samples is reasonable in view of the minute yuantities of these radionuclides available at the Laboratory. Chapter 0524 of the ERDA Manual also states that average tritium activities in off-site water samples may not exceed $3 \times 10^{-3} \mu \mathrm{Ci} / \mathrm{nll}$.

The external whole-body radiation dose to workers in controlled areats may not exceed 5 rem $y$, and the dose to an individual in an uncontrolled area naly not exceed 500 mrent/y. Also, a group of individuals in an uncontrolled area may not receive an average annual dose of more than 170 mrem. 
APPENDIX D

D-1 


\section{Lawrence Livermore Laboratory}

SAMPLING AND ANALYTICAL PAOCEDURES FOR ENVIRONMENTAL MONITORING AT LAWRENCE LIVERMORE LABORATORY

C. L. Lindeken, K. M. Wong, G. L. Seibel, and $R$. S. Griggs

July 14, 1978

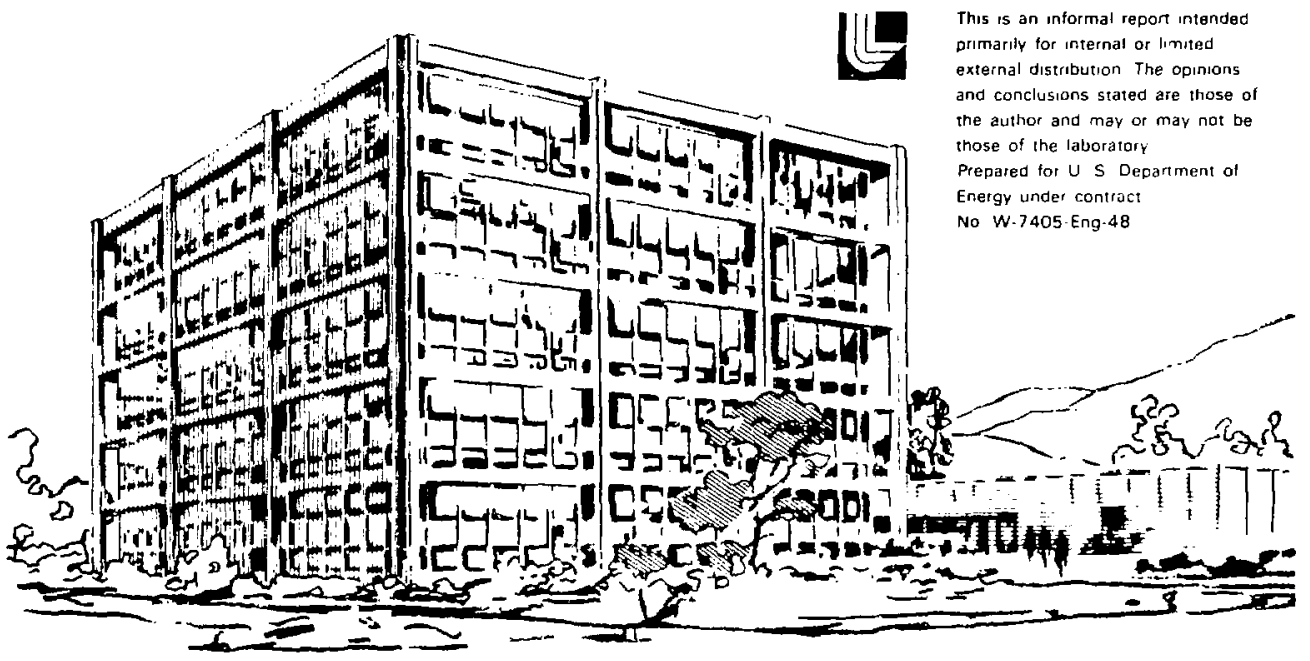


CONTENTS

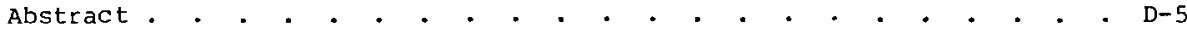

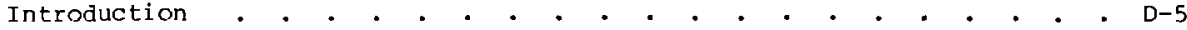

Air Sampling . . . . . . . . . . . . . . . . . . . . D-5

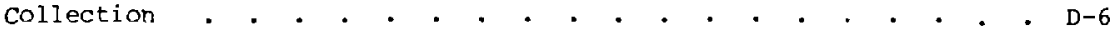

Identification • • • • • • • • • • • • • • • • • • • D-6

Replication • • • • • • • • • • • • • • • • • . • D-7

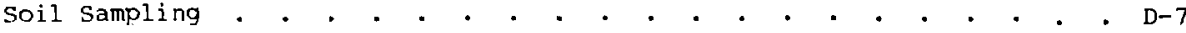

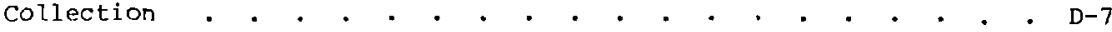

Identification • • • • • • • • • • • • . • • . . . D-7

Replication . . . . . . . . . . . . . . . . . . . D-8

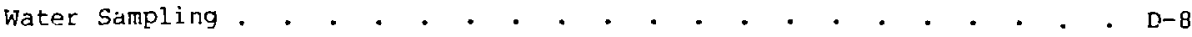

Coilection . . . . . . . . . . . . . . . . . . . D

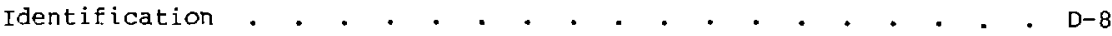

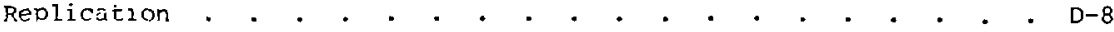

Sewage Sampling

collection

Identification

Replication

Vegrtation Sampling

Collection

Identification

Replication

Milk Samplirg

Air Analysis

Gross Alpha and Beta Counting

Gamma Counting

$238 \mathrm{Pu},{ }^{239} \mathrm{Pu}$

$137 \mathrm{Cs}$

$235 \mathrm{U}, 238 \mathrm{U}$

HTO

Beryllium.

Soil Analysis

Gamma Counting

D-8

D-9

D-9

D-9

D-9

- D-10

D-10

D- 10

- D-10

- D-10

- $\mathrm{D}-10$

- D-1I

D-11

- D-12

- D-12

- D-12

- $\mathrm{D}-13$

D-13

. D-13 
${ }^{238} \mathrm{Pu},{ }^{239} \mathrm{Pu}$. . . . . . . . . . . . . . . . . D-14

${ }^{235} \mathrm{U},{ }^{238} \mathrm{U}$. . . . . . . . . . . . . . . . . . . . . . . . . . . . . . . . . . .

Water Analysis . . . . . . . . . • . . . . . . . . . D-14

Gross Alpha and Beta Activity . . . . . . . . . . . . . D-14

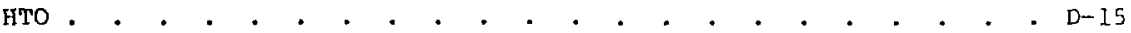

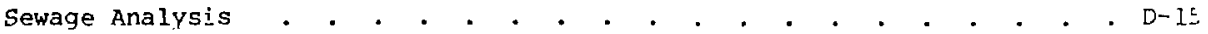

Gross Alpha and Beta Radioactivity . . . . . . . . . . . D-15

Tritium . . . . . . . . . . . . . . . . . . . . D-15

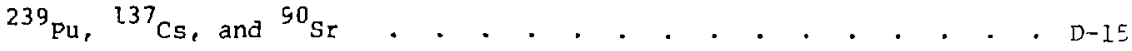

Nonradioactive Metals and Fluorides . . . . . . . . . . . D-17

Fluoride Measurements . . . . . • . . . . . . . . . . D-18

Vegetation Analysis . . . . . . . . . . . . . . . . . . D-li

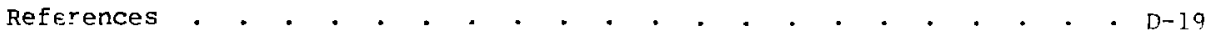




\title{
SAMPLING AND ANALYTICAL FROCEDURES FOR ENVIRONMENTAL
} MONITORING AT IAWRENCE LIVERMORE LABORATORY

\begin{abstract}
lescribed herein are sample collection and analysis proceduros employed in er ironmental monitoring at the Lawrence Livermore Laboratory. An inte al part of the quality assurance program developed for environmental moni ring at Livermore, these procedures provide a basis for verifying that san $p^{n}$ ng and analytical activities are being performed as specified.
\end{abstract}

\section{INTRODUCTION}

'ritten procedures have been prepared for each environmental montoring acti ty at Livermore as part of the quality assurance program developed for envir nmental monitoring at Lawrence Livermore Laboratory (LLL). The sample coltr tion and analysis procedures described herein have been reviewed and appr $\therefore$ d by those responsible for managing the monitoring program. During a progr $m$ audit, such written doclmentation can be used to verify that sampl $\mathrm{ng}$ and analytical procedures meet program specifications.

he "Sampling" sections of this report describe the sampling procedures used or each sample medium monitored. A general description of each medium is us:ally provided. This is followed by the collection procedure used, provizions for sample identification, and a schedule for sample replication. he "Analysis" sections of this report cover sample analysis. General comme ts on each sample medium analyzed are followed by specific descr:ptions of standards and calibrations, analytical procedures, and/or count ng procedures as applicable for each medium.

\section{AIR SAMPLING}

ontinuously operating air samplers are used at LLL to measure the ronce tretion of airborme particulate radioactivity, beryllium, arıd tritiated water. Samplers placed at 6 perimeter locations at LTI and at 10 locations at site 300 measure particulate radioactivity and beryllium. Particulate radioactivity is also measured at 10 off-site locations near the 
Laboratory. Tritiated water samplers are operated at the six LLL perimeter locations and at two off-site locations. In all cases, samplers are so placed as to provide reasonable assurance that any significant concentration of effluents from Laboratory operations would be detected regardless of local meteorology.

\section{Collestion}

\section{Particulates}

LLL perimeter and site 300 particula _ mples are collected on 5.2$\times 10^{-2}-m^{2}$ whatman silters, using average flow rates of $700 \mathrm{l} / \mathrm{min}$. off-site samplers in the Livermore valley use $4.6-\times 10^{-3}-\mathrm{m}^{2}$ Flanders F-700 glassfiber filters operated at a flow rate of $80 \mathrm{l} / \mathrm{min}$. Particulate sample flow rates are calibrated with a spirometer that has been cilibrated against an immersion unit certified by the National Bureau of Standards. Flow rates of Hi-vol air samplers are verified at monthly intervals with a portable field-calibration unit.

\section{Tritiated Water}

Samples of tritiated water vapor are collected oy drawing air through silica-gel-packed columns at flow rates of about $0.5 \mathrm{l} / \mathrm{min}$. Columns are exchanged weekly.

\section{Identification}

\section{Particulates}

Particulate samplers are rur continuously, and sample filters are exchanged weekly. Each filter is identified by location, date on, date off, elapsed sampling time, and flow rate. Filter samples are placed in glassine envelopes and are transported to the laboratory, where this information is transferred to $\log$ sheets and each sample is given a serial number that accompanies it during-analysis. Half of each LLL perimeter and site 300 filter is used for berylliur analysis; the other half is retained for radioactivity measurements.

\section{Tritiated Water}

Tritiated water vapor samplers are run continuously, and silica-gel holders are exchanged biweekly. Each sample is identified by location, date on, date off, clapsed sampling time, and flow rate. This information is transferred to $\log$ sheets in the laboratory, and each sample is giver a serial number that accompanies it during analysis. 


\section{Replication}

\section{Particulates}

At bimonthly intervals, a particulate air sampler is operated in parallel with the permanent sampler at one of the six LLL perimeter locations. This parallel operation is continued for one month, filters are changed weekly, and both filters are submitted for analysi, in the usual manner. Bimonthly rotation of the extra sampler among the six locations ensures samplers are checked annually. The replicate samples are then compared with respect to gross alpha and beta activities and to ${ }^{239} \mathrm{Pu}$ content.

Tritiated water

Parallel sampl ; of tritiated water vapor are collected at LLi perimeter locations during alternate months from those locations in which particulate replicatıs are being collected.

SOIL SAMPLING

Soil samples are collected annually within the Iivermore Valley and at Site 300. Radiocheni al analysis of these samples serves to document ally changes that may have xccurred during the year. Increases in radioactivity that may result from Laboratory operations are brought to the public's attention through annual monitoring reports.

\section{Collection}

Sampling sites are selected in reasonably level areas that represent undisturbed soil. A $2-\pi$ square is marked off with each such area, and an 8.25-cm-dlam coring tool designed at LLL is used to collect $5-\mathrm{cm}$-deep samples at the corners and center of the square. 1

\section{Identification}

The five samples of soil collected from each $2-m$ square are placed in plastic hags and are identified by number. This number is entered in a $\log$ hook, together with the sampling data and a description of the sample location. The number is used to identify the - mple throughout the laboratory analysis and in the annual monitoring report. 


\section{Replication}

During each annual collection of soil samples, at least 108 of the sites are sampled in duplicate. In such collections, twu adjacent 5-cm-deep cores are taken $\mathrm{from}$ the corners and center of each $2-m$ square. Separate composites of t'e five cores are then made, and the composites are identified by successive numbers.

WATFR GAMP:JING

At quarterly intelvals, water samples from varicus sources in the tivermore valley and at site 300 are analyzed for gross alpha and her; radinactivity and for tritium content. These anslyces are performer th ietormine if detectahle changes in radioactivity have accurred.

\section{Ccllection}

Grab samples of such surface snurces as ponds, remks, and reservoirs are obtained with a tethered plastic nail. The samples aro transferron. 4- 2 plastic contalners to which $6.5 \mathrm{~m}$ of concentratoy Has haen

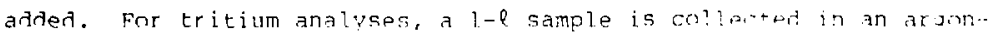
flusher glass containor fitter with a nund-qlass stopper.

\section{Identification}

As samples are collected in the sield, they are raqued with samplino Incation and date. In the lahoratory, each sample is assizned the number that accompanies it furino ana?ysis.

\section{Replication}

During each sample collection periol, at last lus of the water sampies are ruplicates.

SEWAGE SAMPLJNC;

Bewage from the Laboratory is discharqed into the city of livermore's sanitary sewer system. Radioactive or otherwise hazurdws liquid wastes are first tr ated to reciuce concentration levels to within appiicable standards before th' 'y are released into the sanitary sewer. Sewagr samples are collecter from I,LI effluent and trom the trested off luant of the Livermore Water Reclamation Plant (LWRP). Quarterly sampins alm alor collected from the site 300 sewage-oxidation pond. 


\section{collection}

\section{I.LI, Fff ?}

A 24-hr composite of I.I, sewage effluen: is colleoted dally by a

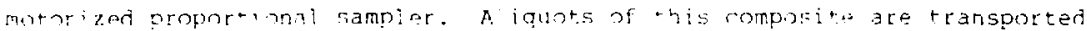

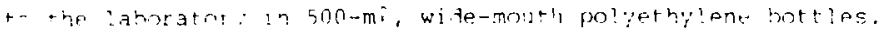

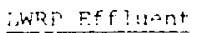

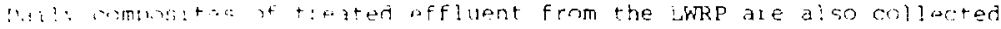

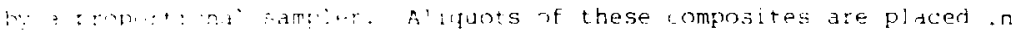

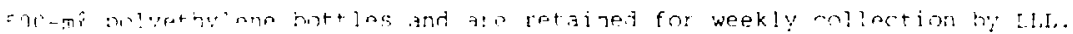
S:to lno sewagkeresiation Pond

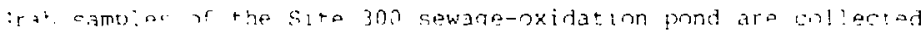

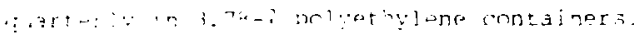

$\because$ int if $\vdots= \pm$ ion

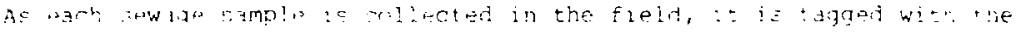

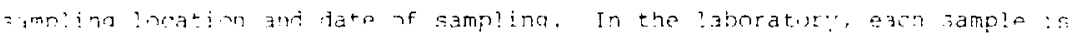

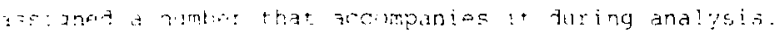

\section{Replisaison}

In. FE.

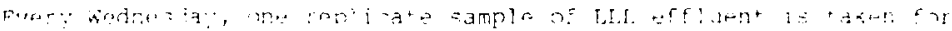

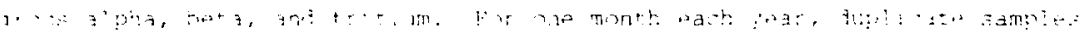

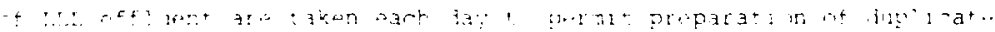

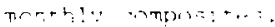

WP Ef? :UEnt

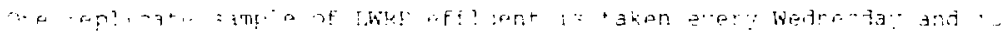

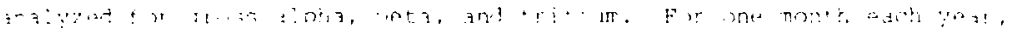

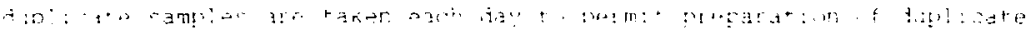
mat

MCETA?ION SAMPSIN:

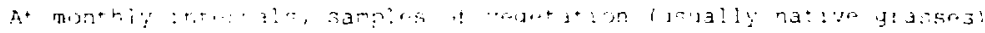

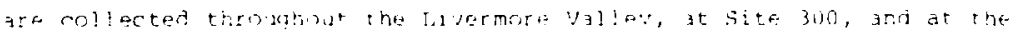

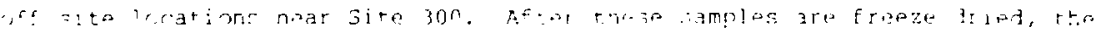

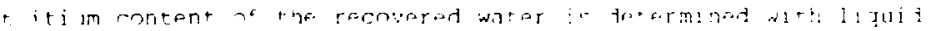
srintiliarior. crintinz. 


\section{Collection}

Samples of vegetation are routinely collected from the same locations each sampling period. Grass samples are pulled up or cut close to the ground, and any soil is discarded. The bulk volume of these samples is usually between 0.5 and $l \ell$. As each sample is collerted, it is placed in a plastic had and frozen in a dry-ice chest to minimize water loss on the bag surface. The duplicate samples collected at each location are later transferred to a freezer in che laboratory.

\section{Identification}

Samples of vegetation collected in the fiejd are tagged according to sample type and lncation. In the laboratory, each sample is assigned a number that accompanies it until the measurement is reported. Measurement data ire permanentlv retained on computer cards.

\section{Replic ztion}

Two samples of vegetation are coilected at each location in case the first sample is lost during analysis or the measuremen. is in question. At least one set of each group of samples collected is aralyzed in duplicate to furnish replicate measurement data.

\section{MILK SAMPLING}

Milk samples are obtained at monthiy intervals from two goat farms located zbout $5 \mathrm{~km}$ south and 5 southeast of the Laboratory. A $3-\ell$ portion of each milk sample is vacuum distilled, and the tritium content of the distillar uater : a determined by liquid scintillation. Each $3-l$ sample is then concentrated hy evaporation and qamma counted.

\section{A.IR ANALYSIS}

Environmental air samples are analyzed for gross alpha and beta activity and for various gamma-emitting radionuclides, plutonium isotopes, uranium isotopes and beryllium.

\section{Gross Alpha and Beta Counting}

After a four-day delay to allow for decay of the radon-thoron daughters, a!l environmental-radioactivity air filters are counted for alpha and beta activity. Counting is done in a Sharp gar-proportional counier using 20-min counting periods. Normally, this counter is used only for environmental samples since a duplicate counting system is provided for routine samples. 
Standards and Calibration

Separate ${ }^{239} \mathrm{Pu}$ and ${ }^{90} \mathrm{Sr}$ standards on 5-cm-diam stainless steel

convoluted planchets are used for determining alpha and beta counting efficiencies, respectively. These standards are traceable to NBS or to equivalent certified sources. Counting efficiency measurements are made with each set of filters counted, and a background count is taken at the beginning of each run and between each set of 10 samples. Records are kept of background and counting efficiency variations in the sharp counter.

\section{Gamma Counting}

Monthly composites of Laboratory perimeter and site $300 \mathrm{filters}$ are analyzed for specific gamma-emitting radionuclides. These filters are sealen in $210-\mathrm{cm}^{3}$, thin-walled aluminum cans and are counted for nominal 1000-min veriods. Counting is done with an $80-\mathrm{cm}^{3}$, low-background Ge(Li) spectrometer that is equipped with a background-suppression systelu. ${ }^{2}$ Standards and Calibration

Low-level uranium-ore (New Brunswick) and NBS river-sediment standards are used periodically to check counting system response. Efficiency calibration checks are made with calibrated sources supplied by the International Asscciation of Environmental Analysts (LAEA), the Environmental Monitorinf Laboratory (EML), or NBS.

$$
{ }^{238} \mathrm{Pu},{ }^{239} \mathrm{Pu}
$$

Following gamma counting, the monthly composite of Laboratory perimeter filters is divided according to sampling location. This composite and that frce site 300 are dry ashed in a $450^{\circ} \mathrm{C}$ muffle furnace. Ashed samples are then dissolved with a $\mathrm{HNO}_{3}-\mathrm{HF}-\mathrm{H}_{2} \mathrm{O}_{2}$ mixture and are equilibrated with a stantardized cesium carrier and tracer amounts of ${ }^{242} \mathrm{Pu}$ and ${ }^{233} \mathrm{U}$. This solution is made $8 \underline{\mathrm{N}}$ with $\mathrm{HNO}_{3}$, the plutonium is oxidized to $\mathrm{PU}^{+4}$ with $\mathrm{NaNO}_{2}$, and the plutonium, cesium, and uranium radionuclides are separated by anion-exchange terhniques.

The ${ }^{137} \mathrm{Cs}$ is collerted first in the $8 \mathrm{~N}$ Eraction. Then the plutonium is eluted with a mixture of concentrated $\mathrm{HCl}-\mathrm{NH}_{4} \mathrm{I}$, and the uranium fraction is cluted with $0.1 \mathrm{~N} \mathrm{HCl}$.

The plutonium fraction is purified by a second anion-exchange separation and is electrodeposited on a platinum disc. Then, ${ }^{238}$ pu and ${ }^{239} \mathrm{Pu}$ are deterrinet by alpha spectrometry. 


\section{Standards and Calibration}

The LLL Heavy Element Group purifies and calibrates internal tracer ${ }^{242} \mathrm{Pu}$ by means of mass spectronetry. ${ }^{3}$ Alpha spectrometry is also used to periodically calibrate ${ }^{242} \mathrm{Pu}$ against ${ }^{236} \mathrm{Pu}$ and ${ }^{239} \mathrm{Pu}$ standards from FML.

$$
137 \mathrm{Cs}
$$

The cesium fraction collected in the plutinium separation is heated to evaporate excess acid. After it is diluted with wator, sodium hydroxide ( $\mathrm{NaOH}$ ) is added to bring the $\mathrm{pH}$ to 2-3 and the cesium is extracted with ammonium molybdophosphate. The cesium is further purifind by ion exchange with a Bio-Rex 40 cation-exchange resin and is then precipitated as $\mathrm{Cs}_{2} \mathrm{PtCl}_{6}$ for yield correction. The precipitate is mounted for ${ }^{137} \mathrm{Cs}$ determination and is counted in a low-background beta counter. Standards and Calibration

standard solutions of ${ }^{137} \mathrm{Cs}$ from EML, LLL, and commercial laboratories are used to prepare efficiency and self-absorption counting standards to calibrate low-background beta detectors.

$$
235 \mathrm{U}, 238_{\mathrm{U}}
$$

The uranium fraction from plutonium separation is converted to sulfate by evaporating to dryness and by fuming with $\mathrm{H}_{2} \mathrm{SO}_{4}$. Further purification is obtained with anion exchange in sulfate form. Then ${ }^{235_{U}}$ and ${ }^{238} U$ are determined with isotopic-dilution mass spectrometry. ${ }^{4}$

\section{Standards and Calibration}

The mass spectrometer is calibrated with NBS uranium sources containing certified quantities of ${ }^{235} \mathrm{U}$, the balance being ${ }^{238} \mathrm{U}$. Mass values are, as noted, based on the use, of ${ }^{233} \mathrm{U}$, and semiannual alpha spectrometry measurements are employed to verify its purity.

\section{HTO}

Water vapor samples are collected biweekly at LLL perimeter lacations by silica-gel samplers operated at flow rates of about $0.5 \mathrm{l} / \mathrm{min}$. The collected water is recovered by vacuum drying at $150^{\circ} \mathrm{C}$, and the HTO is measured by liquid scintillation counting. 


\section{Standards and Calibration}

A primary HTO standard is obtained from NBS. The calibration curve for each counting set is made from eight replicate measurements of a dirution of this primary standard, and the background is determined from eight replicate measurements of a deep-well water sample.

\section{Beryllium}

Bvery month, half of each weekly LLL perimeter and site 300 paper air filter is composited by sampling location. Two paper filters at a time are wet asher with a mixture of $808 \mathrm{nitric}$ and $20 \mathrm{~s}$ perchloric acid. The solutions are then evaporated to l-2 $\mathrm{ml}$, taking care not to allow samples to bake dry. After the samples are diluted with water, they are filtered, any residues are discarted, and the filtrates are diluted to $25 \mathrm{ml}$ with demineralized water. Standards and Calihration

Rervllium standards are prepared with 0.5 and $1-\mu g$ of beryllium per 25 $\mathrm{ml}$ of solution. The recorder readout of the Model 306 Perkin Elmer atomic absorption spectrophotometer is set at $30 \times$ absorbance expansion, and the spectrophotometer is zeroed while aspirating deionized water into the flame. instrument responses from the $0.5-$ and 1 -1/g beryllium standards are then recorded. Following these salculations, the response of each monthly composite is recorded and its heryllium content is calcalated from the calibration data.

SOIL RNALXSIS

Each soil sample collected in accordance with the "Gamma Counting" section below is dried to constant weight at $11.0^{\circ} \mathrm{C}$, is pulverized in a mechanical grinder, and is screened through a 32 -mesh screen to remove pebbles and dry veqetation. The sample is then blended, and aliquots are taken for various analyses.

\section{Gamma Counting}

Approximately $300 \mathrm{~g}$ of the pulvorized and blented soil sample is sealed in a $210-\mathrm{cm}^{3}$, thin-walled aluminum can. It is then counted for a nominal 1000 min in the low-background gamma counter for gamma emitters and ${ }^{238}{ }^{2} .^{2}$ 


\section{standards and Calibration}

Low-level uranium-ore (New Brunswick) and NBS river-sediment standards are used periodically to check counting system response. Efficiency calibration checks are made with calibrated sources supplied by IAEA, EML, or NBS.

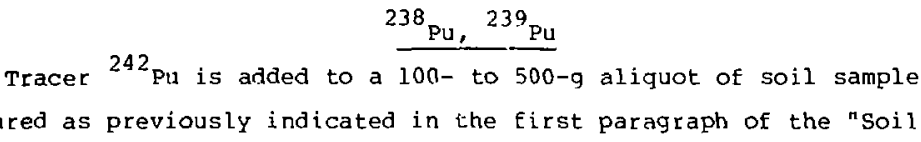
prepared as previously indicated in the first paragraph of the "Soil Analysis" section of this paper. The sample is then acid leached with $\mathrm{HNO}_{3}$-HCl acid, using the EML soil-leach method. ${ }^{5}$ Plutonium isotopes are separated, purified, and analyzed in accordance with the "Air Analysis" section on ${ }^{238} \mathrm{Pu}$ and ${ }^{239} \mathrm{Pu}$.

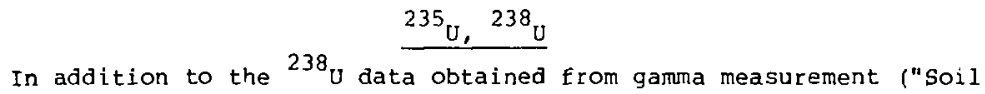
Analysis" section on gamma counting), natural isotopic content and depleted uraniun concentration are also determined by isotopic-dilution mass spectrometry in certain selected samples. These sampies are analyzed in a manner similar to the procedure given in the "Air Analysis" section on ${ }^{238} \mathrm{Pu}$ and ${ }^{239} \mathrm{Pu}$ and on ${ }^{235} \mathrm{u}$ and ${ }^{238} \mathrm{u}$.

\section{WATER ANALYSTS}

Environmental water samples are analyzed for gross alpha and beta activity and for tritium content.

\section{Gross Alpha and Beta Activity}

Each 500-ml water sample is acidified with $\mathrm{HNO}_{3}$. Then $30 \mathrm{z} \mathrm{H}_{2} \mathrm{O}_{2}$ is added, and the sample is evaporated to near dryness and transferred to 5-cm-diam planchets of convoluted stainless steel. After drying and flaming, the sample is counted for $30 \mathrm{~min}$ in a Nuclear-Chicago proportional counter.

\section{standards and Calibration}

$$
\text { The }{ }^{239} \mathrm{Pu} \text { and }{ }^{90} \mathrm{Sr} \text { standards are used with every sample set isee }
$$

the "Soil Analysis" section on standards and calibration). Instrument background measurements are made between evey 10 sample-counting measurements. 


\section{HTO}

Samples collecter in argon-flushed glass bottles are distilled under argon. A 250-ml aliquot of sample is electrolytically enriched, using the enrichment technique described by ostlund. ${ }^{6}$ Following enrichment, the HTO content of the sample is determined with either liquid-scintillation or internal qas-proportional. counting.

\section{Standards and Calibration}

Each enrichment set contains duplicate aliquots of the secondary HTO standard to verify the enrichment factors. See the "Standards and Calibration" section of "Air Analysis" on HTO for scintillation counter standards and wibration. For internal gas-proportional counter standardization, replicate samples of a secondary H'PO standard are reduced to $H T$ and are counted after 10 unknown samples are $r$ un.

\section{SEWAGE ANALYSTS}

Fxcept for tritium analyses, all sewage samples are wet digested with a mixture of $208 \mathrm{HClO}_{4}$ and $808 \mathrm{HNO}_{3}$. Those sewage samples fer tritium analysis are distilled to reduce self absorption before counting.

\section{Gross Alpha and Beta Radioactivity}

A 100-ml quanticy of LWRP effluent is wet digested, and the residue is transferred to 5-cm-diam planchets and is counted in accordance with the procedures in the "Water Analysis" section on HTo. Aliquots of $500 \mathrm{ml}$ are taken for all other gross a?pha and beta measurements.

\section{Tritium}

A $1-\mathrm{m} l$ aliquot of sewage sample is added to $10 \mathrm{~m} l$ of Packard Insta-Gel in a 25-ml screw-cap glass bottle. Then, $1 \mathrm{ml}$ of tap water is used to prepare a background for the sample, and both are placed in the refrigerated detection chamber of the Packard scintillation counter for a 2-hr temperature-equilibration period prior to counting. The sample and hackground are each counted for $100 \mathrm{~min}$.

$$
239 \mathrm{Pu}, 137 \mathrm{Cs} \text {, and }{ }^{90} \mathrm{Sr}
$$

Nuclear Chemistry analyzes monthly composites of Laboratory sewage effluent and treated effluent from LWRP for ${ }^{239} \mathrm{Pu}$ and ${ }^{137} \mathrm{Cs}$. Duplicate composites are prepared by Hazards Control and are analyzed for ${ }^{239} \mathrm{pu}$ and ${ }^{90} \mathrm{Sr}$. 


\section{Procedure}

Daily samples of sewage effluent are combined for the monthly composite, are acidified with $3 \mathrm{~N} \mathrm{HCl}$, and ${ }^{242} \mathrm{Pu}$ and cesium carrier are added. Ten milliliters of saturated $\mathrm{KMnO}_{4}$ are added to the mixture, and the $\mathrm{PH}$ is adjusted to $8-10$ with $3 \mathrm{~N} \mathrm{NaOH}$. Then, $150 \mathrm{ml}$ of $\mathrm{MnCl}_{2}$ are added, and the plutinium coprecipitates with the $\mathrm{MnO}_{2} \cdot^{7}$ Each sample is later filtered through a $1-\mu m$ cotton filter cartridge, which is then dried and ashed at $475^{\circ} \mathrm{C}$. The filtrate is acidified to $\mathrm{pH} 1-3$ with $3 \mathrm{~N} \mathrm{HCl}$, and the cesium is extracted with $5 \mathrm{~g}$ of AMP. The sample is then refiltered, and the cartridge is dried and ashed.

The plutonium filter is heated with 100 ml of concentrated HNO ${ }_{3}$, and the $\mathrm{MnO}_{2}$ is dissolved with $30 \mathrm{z} \mathrm{H}_{2} \mathrm{O}_{2}$. The volume of solution is then recuced to about $50 \mathrm{~m} \ell$, and the sample is filtered through $934-\mathrm{AH}$ glass-fiber filter paper. The plutonium is oxidized with $\mathrm{NaNO}_{2}$ purified by anion exchange, is electroplated, and is counted by solid-state alpha spectrometry.

The ashed cesium filter is dissolved in acid, excess ammonia is evaporated with NaOH, and the cesium is reextracted with $1 \mathrm{~g}$ of AMP. Further purification is carried out as outlined in the "Air Analysis" section on ${ }^{137} \mathrm{Cs}$.

\section{Radiahemical Separations}

The procedure outlined in the "Air Analysis" section on ${ }^{238} \mathrm{Pu}$ and ${ }^{239} \mathrm{pu}$ is used to purify ${ }^{239} \mathrm{pu}$. The purified ${ }^{239} \mathrm{pu}$ is then electrodeposited and is counted by solid-state alpha spectrometry.

The Sr-Y is washed from the anion column (used in plutonium separation) with $8 \mathrm{~N}_{3} \mathrm{HNO}_{3}$. The combined washings are then evaporated and are converted to chloride by repeated HCl additions followed by evaporation. Residue is taken up in $8 \mathrm{~N}$ HCL, transferred to a freshly prepared Dowex 1 column, and the column is washed with $8 \mathrm{~N} \mathrm{HCl}$. The washings are later collected and evaporated to near dryness. Water is added, and the solution is adjusted to $\mathrm{pH} 1.5$ with $\mathrm{Na}_{4} \mathrm{OH}$. This solution is extracted twice with 2082,2 -diethyl hexyl phosphoric acid, and the organic phase is washed twice with $0.5 \mathrm{~N} \mathrm{HCl}$ and $1 \mathbb{N} \mathrm{HCl}$. The $\mathrm{Y}$ is then back extracted with three 20-ml portions of $\mathrm{HCl}$, the solution is evaporated to about $10 \mathrm{ml}$, and the $\mathrm{Y}$ is precipitated by adding HF. The $\mathrm{YF}_{3}$ is dissolved and precipitated as hydroxide; then it 
is redissolved with $\mathrm{HCl}$. The $\mathrm{Y}$ is then precipitated as oxalate and is filtered and converted to oxide in a muffler furnace set at $900^{\circ} \mathrm{C}$ for 1 hr. The ash is weighed, dissolved in $\mathrm{HNO}_{3}$, transferred to a 5-cm-diam planchet, and dried. After drying, the ash is beta counted.

\section{Nonradioactive Metals and Fluorides}

Monthly composites of LLL sewage effluent are analyzed for copfer and chromium with a Model 306 Perkin Elmer atomic-absorption spectrophotometer. Aliquots of these composites are also analyzed for cadmium, iron, lead, nickel, silver, zinc, and fluoride.

A monthly composite of Laboratory sewage effluent is prepared by combining 500-ml daily samples. Following each 500-ml addition, the solution is evapnrated with $\mathrm{HNO}_{3}$ to approximately $100 \mathrm{ml}$. After compositing is complete and orqanic matter has been destroyed by $\mathrm{HClO}_{4}$ and $\mathrm{HNO}_{3}$ treatments, the sample is evaporated to near dryness. The residue is taken up in about $30 \mathrm{ml}$ of deionized water, is filtered through a sintered glass funnel, and any filter residue is discarded. The filtrate is made up to $100 \mathrm{~m}$ l in a volumetric f.lask.

\section{Standards and Calibration}

The atomic-absorption spectrophotometer is calibrated with solutions of the metals or compounds of the metal of interest. This spectrophotometer is zeroed with deionized water and is calibrated with standards. Dilution of stock solutions and the monthly composite may be necessary to obtain readings within the spectrophotometer's linear response region. Following calibration, the monthly composite sample is aspirated into the flame, and concentrations are read out directly.

Precision Checks. The monthly composite sample is used to prepare four ailutions. The first dilution provides a concentration near the limit of sensitivity; two dilutions provide intermediate concentrations; and the fourth provides a concentration near the upper limit of the spectrophotometer's linear response region. To reflect maximum interference, they are analyzed in order of highest concentration, lowest concentration, and then by the two intermediate concentrations. This set of measurements is repeated seven times, and the average and standard deviation for each concentration are recorded. 
Accuracy Checks. Using the monthly composite, accurace checks are performed by adding known amounts of the metal of interest to the low and intermediate concentrations. The amount of metal added to the low concentration is designed to double in concentration, and the amount of metal aried to the intermediate concentrations is sufficient to result in concentrations that are within 258 of the upper limit of the spectrophotometer's linear response region. As in the precision measurements, seven replicate determinations are made at each concentration, and accuracy is expressed as percent recovery based on the average recovery of th? seven replicates.

\section{Fluoride Measurements}

Fluorides in LLL sewage effluent are determined with a specific ion-electrode measurement. Daily additions of $100-m l$ aliquots of sewage effluent are used to prepare a monthly composite sample. This composite sample is stcred in a plastic bottle, and no chemical treatment or evaporation is employed. At the end of the month, an aliquot of the composite sample is analyzed for fluorifes with an Orion Model 401 specific ion meter equipped with a lanthanum fluoride electrode. Precision and accuracy measurements are conducted quarterly in a manner similar to those described for metals in the "Nonradioactive Metals and Fluorides" section on precision and accuracy checks above.

\section{VEGETATION ANALYSTS}

Frozen vegetation is transferred to freeze-drying equipment, and a 10-um vacuum is estabished. Recovered water is collected in a receiver chilled with ary ice and Dowanol (dipropylene methyl ether). The vacuum is checked periodically, and dry ice is added as needed over a four-day period. Liquid scintillation counting is then used to analyze an aliquot of the recovered water for tritium content.

\section{Stantards and Calibration}

See the "Air Analysis" section on standards and calibration for HTO. 


\section{REFEREN'CES}

1. C. L. Lindeken, P. H. Gudiksen, J. W. Meadows, K. O. Hamby, and L. R. Anspaugl, Environmental Levels of Radioactivity in Livermore Valley Soils, Lawrence Livermore Laboratory, Rept. UCRL-74424 (1973).

2. D. C. Camp, C. Gatrousis, anã L. A. Maynard, "Low Background Ge(Li) Detector Systems for Radioenvironmental Studies," NuCl. Instrum. Meth. 117, 189 (1974).

3. P. G. Johnson, R. D. Carver, and R. J. Dupzyk, Preparation of ${ }^{242} \mathrm{Pu}$ for Use as an Alpha Spectrometry and Mass Spectrometry Tracer, Lawrence Livermoze Laboratory, Rept. UCRL-78596 (1976).

4. R. J. Dupzyk, R. D. Carver, and I. A. Dupzyk, Isotope Analysis of PIutonium Samples by Isotope Dilution Mass Spectrometer, Technical Report Series 169 - STI/DOC 10, 2nd Panel on Reference Methods for Marine Radioactivity Studies, International Association of Environmental Analysts (1972).

5. "Kadiochemical Determination of Plutonium in Soil Leaching," ERDA 7ealth and Safety Laboratory Procedures Manua1, E-Pu-06-01, HASL-300 (1972).

6 H. G. Ostlund and E. Werner, "The Electrolytic Enrichment of Tritium and Deuterium for Natural Tritiun Measurements," Tritium in the Phys. and Biol. SCi. 1 (1962).

7. K. M. Wong, G. S. Brown, and V. E. Noshkin, "A Rapid Procedure for Pu Separation in Large volumes of Fresh and Saline Water using $\mathrm{MnO}_{2}$ Co-precipitation," J. Radioanal. Chem. 42, 7-15 (1979). 


\section{APPENDIX E. METHOD OF DOSE CALCULATIONS}

The doses shown in this report have been calculated using the models and methods in the Nuclear Regulatory Commission Regulatory Guide 1.109. "Calculating Annual Doses 10 ilan irom Routine Releases of Reactor Efflue.t." Examples of these calculations and assumptions are shown in this appendix.

\section{ANNUAL DOSE FROM POTABLE WATER}

Assuming that all water sampled is available as drinking *atc., the annual whole body jose for tritium has been calculated using the following equation:

$$
\mathrm{R}_{\text {totul body }}=\mathrm{C}_{\mathrm{w}} \mathrm{U}_{\mathrm{w}} \mathrm{D}_{\mathrm{w}}
$$

where

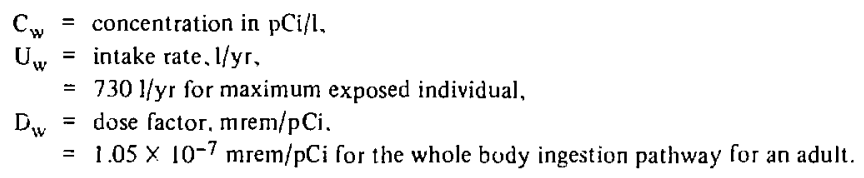

$R_{\text {total body }}=$ annual dose in mrem to the total body from ingestion of 730 litres of potable water with concentration $C_{w}$.

\section{ANNUAL DOSE FROM FORAGE-COW-MILK PATHWAY FOR TRITIUM IN VEGETATION}

Assuming that all the feed for the cattle was pasture grass, the annual whole body dose per $\mu \mathrm{Ci} / \mathrm{ml}$, HTO for the maximum exposed individual has been calculated using the following equation:

$$
\begin{gathered}
\mathrm{D}_{\text {total body }}=\mathrm{D}_{\text {veg }}+\mathrm{D}_{\text {meat }}+\mathrm{D}_{\text {milk }} . \\
\mathrm{D}_{\text {veg }} \text { (leafy vegetables) }=\mathrm{U}_{\text {veg }} \times \mathrm{C}_{\mathrm{veg}} \times \mathrm{D}_{\mathrm{HTO}} .
\end{gathered}
$$

where

$$
\begin{aligned}
\mathrm{U}_{\mathrm{veg}}= & \text { intake rate, } \mathrm{kg} / \mathrm{yr},=64 \mathrm{~kg} / \mathrm{yr} \text {, for maximum exposed individual, } \\
\mathrm{C}_{\mathrm{veg}}= & \text { concentration ir } \mathrm{pCi} / \mathrm{kg}=\frac{\mathrm{pCi} / \mathrm{kg}}{\mu \mathrm{Ci} / \mathrm{ml}} \times \mathrm{C}_{\mathrm{veg}} \mu \mathrm{Ci} / \mathrm{ml} \text { (measured), } \\
\mathrm{D}_{\text {HTO }}= & \text { dnse factor, mrem } / \mathrm{pCi}=1.05 \times 10^{-17} \mathrm{mrem} / \mathrm{pCi} \text { for }{ }^{3} \mathrm{H} \\
& \text { for the adult whole body ingestion pathway. }
\end{aligned}
$$




$$
D_{\text {meat }}=U_{\text {meat }} \times C_{\text {nical }} \times D_{\text {HTO }}
$$

where

$$
\begin{aligned}
& \mathrm{U}_{\text {mial }}=110 \mathrm{~kg} / \mathrm{yr} \text {. } \\
& D_{1100}=1.05 \times 10^{-7} \mathrm{mrem} / \mathrm{pci} \text {. } \\
& C_{\text {meal }}=\left(F_{p}\right)\left(Q_{p}\right)\left(C_{v e g}\right) \exp \left(-\lambda_{j} t_{s}\right) \text {. } \\
& \mathrm{F}_{f}=\text { fraction of daily intake of nuelide per } \mathrm{kg}_{\mathrm{g}} \text { of animal/fish. days } / \mathrm{kg} \text {. } \\
& Q_{1}=\text { amount of feed consumed, } \mathrm{kg} / \mathrm{dal} \text {. }
\end{aligned}
$$

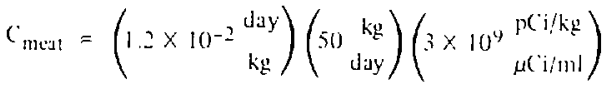

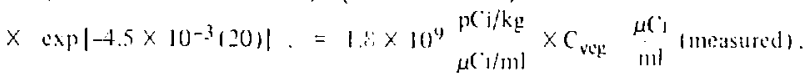

$$
\begin{aligned}
& c_{\text {ser }}=\text { same as above. } \\
& \lambda_{1}=\text { radiological decay const unt. day } y^{-1} \text {. } \\
& I_{1}=\text { ime between slaughter } \text { io consumption. diys } \\
& \mathrm{D}_{\mathrm{m} 1 \mathrm{lk}}=\left(\mathrm{U}_{\mathrm{mulk}} \times \mathrm{C}_{\mathrm{mllk}} \times \mathrm{D}\right)_{11 \mathrm{IO}}
\end{aligned}
$$

whers

$$
\begin{aligned}
& U_{\mathrm{mulk}}=3101 / \mathrm{yr} . \\
& \mathrm{D}_{\mathrm{HTO}}=1.05 \times 10^{-7} \mathrm{mrem} / \mathrm{pci} \text {, } \\
& C_{\text {nilk }}=I_{m} Q C_{\text {ven }} \exp \left(-\lambda_{i} \mathbf{l}\right) \text {. } \\
& F_{m}=\text { fraction of daily intake of nuclide per litre of milk. day fitres. } \\
& Q_{1}=\text { amounl of feed consumed. } \mathrm{kg} / \mathrm{day} \text {. } \\
& C_{v{ }^{\prime \prime}}=\text { same as above. } \\
& \lambda_{1}=\text { radiologicial decaly conslant. days }{ }^{-1} \text {. } \\
& t_{i}=\text { irsnsport time from the feed to milk receptor. }
\end{aligned}
$$

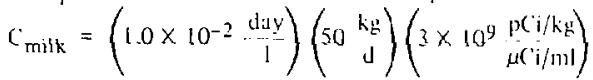

$$
\begin{aligned}
& \times \exp \left[-4.5 \times 10^{3}(2)\right]=1.5 \times 10^{9}{ }_{\mu \mathrm{Ci} / \mathrm{ml}}^{p \mathrm{Ci} / 1} \times\left({ }_{\text {ver }} \underset{\mathrm{ni}}{\mathrm{ni}} \text { (measured }\right) \text {. } \\
& \mathrm{D}_{\mathrm{tsLil}}=\left(2.04 \times 10^{4} \frac{\mathrm{mrem}}{\mathrm{uCi} / \mathrm{ml}}\right) v_{\mathrm{geg}}+\left(2.07 \times 10^{4} \frac{\mathrm{mrem}}{\mu \mathrm{Ci} / \mathrm{ml}}\right) \text { meat } \\
& +\left(4.88 \times 10^{4} \frac{\mathrm{mrem}}{\mu \mathrm{Ci} / \mathrm{ml}}\right) \text { milk }=8.96 \times 10^{4}-\frac{\mathrm{mrem}}{\mu \mathrm{Ci} / \mathrm{ml}} \times \mathrm{C}_{\text {veg }}^{\mu \mathrm{Ci}} \text { (measured) } .
\end{aligned}
$$

\section{ANNUAL POPULATION DOSE}

To calculate the "fence-line" site boundary, nearest resident, and population doses. i continuous point source computer cude based on the Gaussian plume model was used. 
where

$$
\begin{aligned}
& x_{i} \mathrm{Q}=\text { diffusion patameler, sec } \mathrm{m}^{3} . \\
& Q=\text { retedse ints. (1) } \\
& 3.17 \times 10^{4}=1 \times 10^{12} \times 1 / 315 \times 10 \%
\end{aligned}
$$

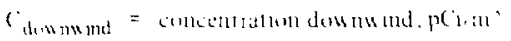

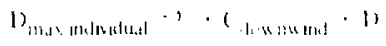

"1)'se

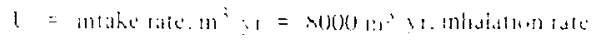

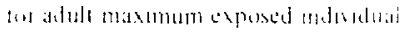

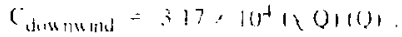

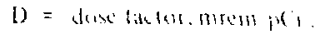

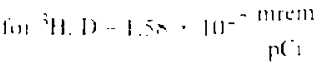

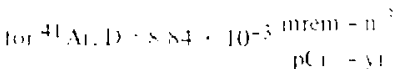

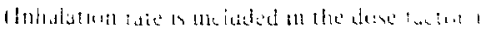

$$
\begin{aligned}
& \text { (1) } 150.0=1,1^{+1} \text {, , , 1 } \\
& \text { (1) } 13 . \mathrm{D}=1) 1^{+1}+111
\end{aligned}
$$

1)

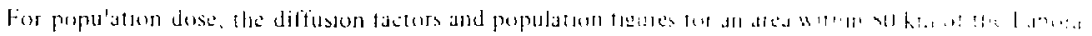

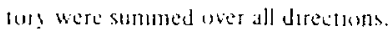

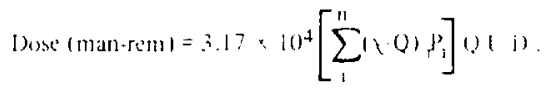

where

$$
\begin{aligned}
& {\left[\sum_{i}^{n}(x / Q){ }_{j} P_{i}\right]=\begin{array}{l}
\text { Summation of the }(x / Q) \text { lor regun } 1 \\
\text { times the population in region i for all reguons n. Man-sec }
\end{array}} \\
& Q \quad=\text { release rate. (i/yr. } \\
& \mathrm{U}=\text { inhalation rate, average individual (adult). } \\
& \mathrm{D}=\text { Jose far:or. rem } / \mathrm{pCi} \text {. } \\
& \text { Duse = man-rem. }
\end{aligned}
$$

